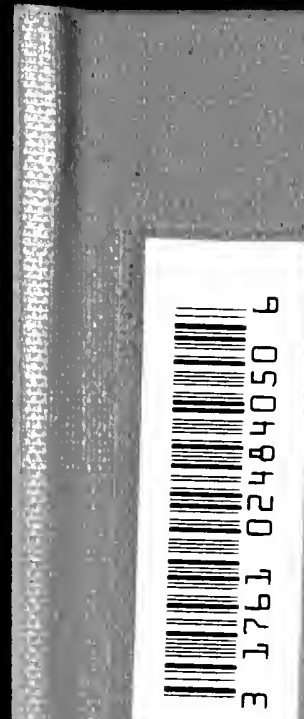

OK

976

KTE

c.1.

ESCI 


\section{Digitized by the Internet Archive in 2007 with funding from Microsoft Corporation}




THE NEW FLORA

OF THE

VOLCANIC ISLAND

OF

KRAKATAU 
CAMBRIDGE UNIVERSITY PRESS WAREHOUSE, C. F. CLAY, MaNager.

Ilonon: FETTER LANE, E.C.

(FDinfurgy: Ioo, PRINCES STREET.

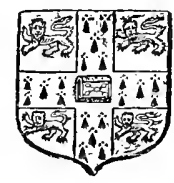

Ileip?ig: F. A. BROCKHAUS.

Grrlin: A. ASHER AND CO.

frés Work: G. P. PUTNAM'S SONS.

13ombay and Calcutta: MACMILLAN AND CO., Lrd. 



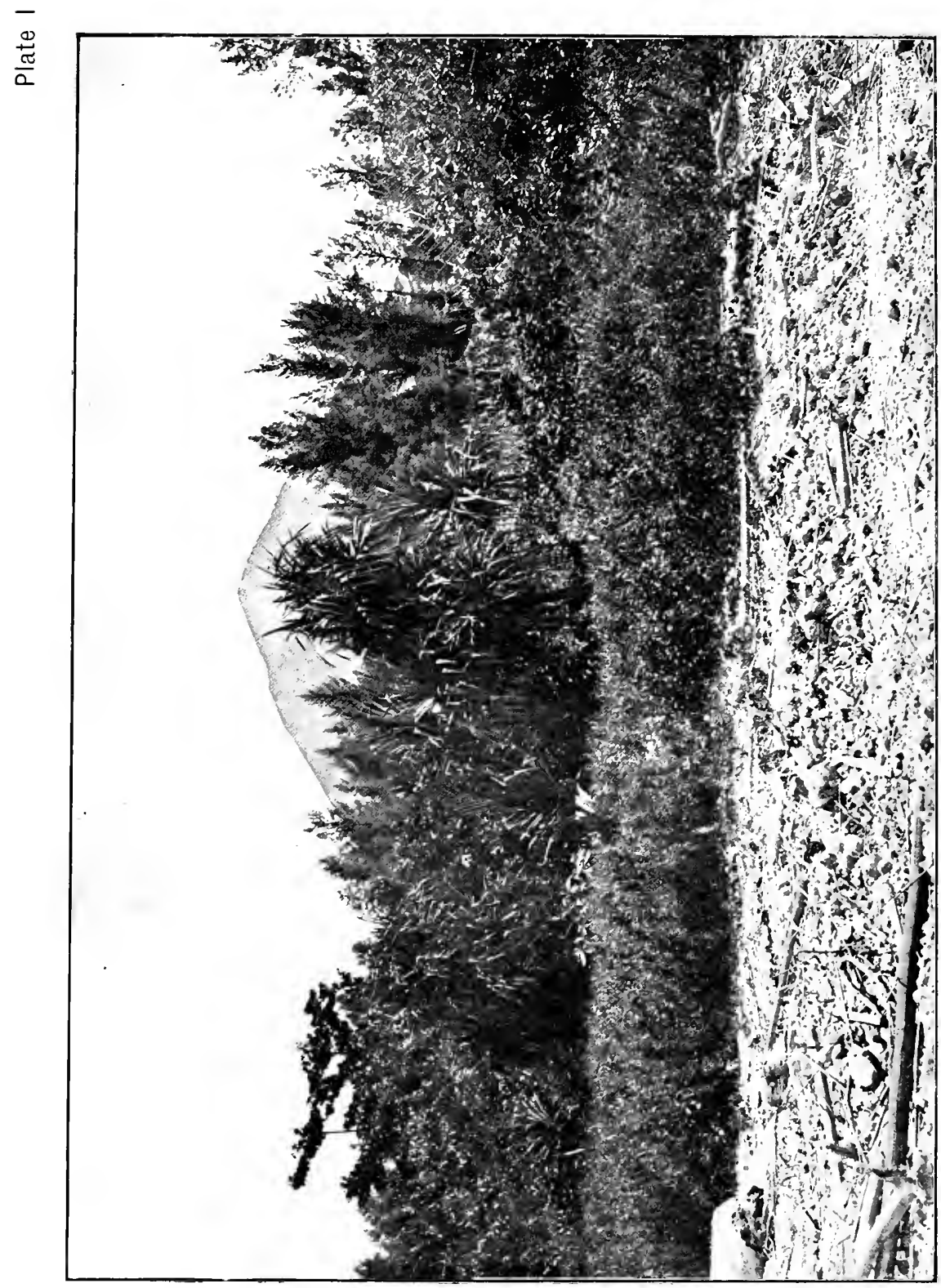




\title{
THE NEW FLORA
}

\section{OF THE VOLCANIC ISLAND \\ OF KRAKATAU}

\author{
BY \\ A. ERNST, Ph.D. \\ PROFESSOR OF BOTANY IN THE UNIVERSITY OF ZÜRICH \\ TRANSLATED BY \\ A. C. SEWARD, F.R.S. \\ PROFESSOR OF BOTANY IN THE UNIVERSITY OF CAMBRIDGE
}

\begin{abstract}
WITH TWO SKETCH-MAPS AND THIRTEEN PHOTOGRAPHS
\end{abstract}

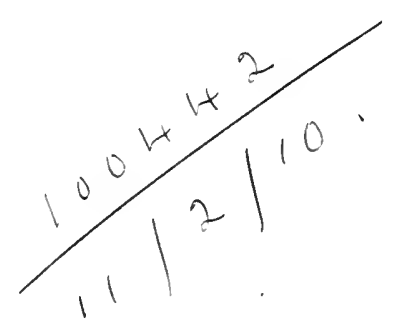

Cambridge :

at the University Press

$$
\text { I } 908
$$




\section{Tambriđge:}

PRINTED BY JOHN CLAY, M.A.

AT THE UNIVERSITY PRESS.

$$
\begin{aligned}
& \text { QK } \\
& 976 \\
& K 7 E 7
\end{aligned}
$$




\section{PREFACE}

THE following pages consist mainly of an account of an expedition to the volcanic island of Krakatan which I had an opportunity of making in the spring of 1906 in company with some other botanists. The work was originally published in the Vierteljahrsschrift der naturforschenden Gesellschaft in Ziirich (Jahrgang 52, 1907): a few reprints only were available for purchase. I therefore agreed with pleasure to the proposal made to me by the Cambridge University Press to publish an English translation, particularly as Professor Seward, who carried out the preliminary negotiations, kindly offered to be the translator. I wish to express my cordial thanks to him. I would also thank the Syndies of the University Press for the care with which the volume has been produced.

Four hitherto unpublished photographs have been added to those published in the German edition. I have also taken the opportunity of making a few corrections and additions, so that the English translation may be regarded as a second edition of the original work.

\section{A. ERNST.}

ZüriciI,

Scptember, 1908.

\section{NOTE BY THE TRANSLATOR}

THE umique example, aftorded by the development of the New 1 Flora of Krakatan, of the colonisation of an island, completely deprived of vegetation by a series of volcanic eruptions, is a sufficient justification for the publication of Professor Erust's pamphlet in an English form.

The additional photographs (Plates V. and VII.) referred to by the Author in the Preface have been reproduced from prints kindly supplied by Professor Ernst from his own negatives. A few references and other additions for which the translator is responsible are enclosed in square brackets. To Professor and Mrs Ernst I am greatly indebted for several corrections and additions which they have made in the course of their careful revision of the English text: I am indebted also to Colleagues in the Botany School for help in regard to certain passages in the translation.
A. C. SEWARD.

Botany School, Cambridge, September, 1908. 



\section{CON'TENTS}

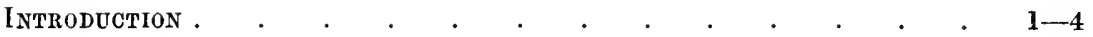

I. Results of the visits of 1886 and 1897 . . . . . . 5-8

II. The Expedition of April 24-27, 1906, to the Sunda Strait region and to Krakatau . . . . . . . 8-37

1. Vegetation and Flora of the Coral Island of Edam . 9-15

2. On the beach at Vlakke Hoek (Sumatra) . . . 15-18

3. In the Sunda Strait; winds and ocean-currents . . 19-23

4. On the south-west coast of Java; Java's First Point . 23-26

5. On Krakatau and Verlaten Islands . . . . 26-37

III. The present composition of the Flora of Krakatau . . . 37-48

IV. Biological conditions on Krakatau . . . . . . 48-53

V. The relative importance of the different agents of plant-dispersal in the colonisation of the Krakatan Islands . . . . 53-6s

1. Ocean-currents . . . . . . . . . 54-58

2. Seed-dispersal by birds . . . . . . . 58-60

3. Dispersal of fruits and seeds by wind . . . . . 60-66

4. Part played by the several agents of dispersal in the development of the present Flora of Krakatau . $66-68$

VI. Snccession of plant-associations and the future character of the vegetation of Krakatau . . . . . . . . 68-72

Bibliography . 


\section{PLATES}

I. Narrow Drift Zone and Pes-caprae Zone, Strand-forest

(south-east coast of Krakatau) . . . Frontispiece

II. Map of the Sunda Strait.

Sketch-map of the Krakatan Islands (after Verbeek). . To face p. 4

1II. FIG. 1. View of Krakatan from the North.

Fig. 2. Peak of Rakata $(832 \mathrm{~m}$.) and the fractured rock-face , 23

IV. FIG. 3. Drift-zone on the south-east coast of Krakatau.

Frg. 4. Level beach between the vertical rock-face and the promontory of Zwarte Hoek . $\quad \cdot \quad$. . . $\quad, \quad, \quad 27$

V. Frg. 5. Casuarina equisetifolia in the Strand-forest of Krakatau.

FIG. 6. The new Strand-forest on the south-east coast of Krakatan . . . . . . . . . , 28

VI. Fis. 7. Young coconut palm at the upper edge of the tidelevel (south-east coast of Krakatau).

Fig. 8. Pandanus on the beach (east coast of Krakatau)

VII. FIG. 9. Luxuriant group of Pandanus plants on the east coast of Krakatau.

FIa. 10. Spinifex squarrosus with spherical heads of fruit

VIII. FIG, 11. Clearing in the Strand-forest.

FIG. 12. Grass-steppe in the interior of Krakatau 


\section{INTRODUCTION}

A quarter of a century ago the small group of islands, Krakatau ${ }^{1}$, Verlaten island, and Lang island, lying in the middle of the Sumda Strait between Java and Sumatra, was the scene of the most violent volcanic outburst of historic times. The three islands enclose an almost circular basin approximately to square kilometres $[25 \mathrm{sq}$. miles] in area. Before the terrific explosion, which lasted from August 26th to August 28th, 1883, the northern part of Krakatau which was then 9 kilometres long and 5 kilometres broad [ $5 \frac{1}{2} \times 3$ miles] was separated from the other two islands by narrow arms of the sea. On the south side the peak Rakata rose in the form of a steep cone to a height of 832 metres [2728 feet]; on the slope of this, near the eentre of the island, was situated the many-peaked lill of Daman, 400 metres [ 1350 feet] high, the remnant of an amular eraterwall. Towards the north the hilly region of the Perboewatan,

1 The official local names are Poeloe (island) Rakáta for Krakatan, P. Sertoeng for Verlaten island, P. Rakát:t Ketjil for Lang island. Verbeek was mable to obtain any definite information as to the meaning of the word Krakatau either from published sources or as the result of enquirics. The official designation Rakáta appears to be an altered form, as the word occurs in Malay writings also as Kalkata and Karkata. The last name appears as early as 1611 on a small map of the Sunda Strait. l'ossibly the name of the island eomes from the Sanskrit Karta, Karkata, Kartataka, which means Crah. Junghuln also states (Jara, seine Gestalt, Pfluzendecle unel innere Buuart, Leipzig, 1854, Vol. r. p. 1) that Rèkata or Rakata is, in the old Javan language (the so-called Kawi language), the term for Crab; hence the name Poeloe Rakáta wonld possibly assume the form Crab-island. The present form Krakatan has perhaps arisen from the translation of Rakata into the langrage of sailors. Since the eruption the name Krakatan, which had alrealy become more commonly used by the natives than Rakáta, has passed into general use. Other forms such as Krakatioe, Krakatoa, Krakatoea, which oceur in the literature, are unknown in the Malay Archipelago. We therefore follow Verbeek in calling the island Krakatau and its highest peak liakáta.

[In the Royal Society's volume on Krakatan (see note 1, p. 2), the form Krakatoa is used, and this spelling has become general in Lingland; as, however, there appears to be no sufficient reason for departing from the more widely accepted form Krakatau I have followed Professor Ernst in adopting this form. A. C. S.] 
dominated by several small elevations, extended to the coast ${ }^{1}$. The whole island, from the beach to the summit of Rakata, was covered with an impenetrable forest. Verbeek who paid a short visit in July 1880 to the northern part of the minhabited island, which has since disappeared, found some lava-streams which reached the coast only in the Perboewatan region ; these were covered by a sparse vegetation and their surface was but slightly weathered. The lava-streams were probably formed during the only recorded eruption of 1680.

For a long time the island had been regarded as an extinet volcano. On May 20th, 1883, a new crater on Perboewatan suddenly became active, the activity being accompanied by lond explosions which were heard for a considerable distance over Java and Sumatra, and after a few days a large part of the island and a portion of Verlaten island were covered with a layer of ash and pumice to a depth of 1 metre. On the north side of the highest peak, and here and there over the whole of the northern part of Krakatan, stems of trees conld still be seen rising above the grey grom as miserable remnants from the former luxuriant forest; while on the south side of the cone, on Lang island and on a fourth island, Poelsche Hoed (Polish Hat), situated between Lang and Verlaten islands, which has completely disappeared since the eruption of August 27 th, the vegetation suffered but little.

In June a second crater was formed at the foot of Danan, which threw out ashes and pumice. At the begiming of August a third crater, together with numerons fissures which gave off steam and smoke, appeared on the sonthern slope of Danan; this was afterwards completely shattered and served as the main crater during the last ernptions.

The outbursts increased in frequency and culminated in the terrible eatastrophe of Angust 26th and 27th, the effects of which were felt over almost the whole surface of the earth. The explosions were heard not only throughont the Malay Archipelago, but also in Ceylon, Burma, Manilla, New Guinea and on the west coast of Anstralia ${ }^{2}$. At Batavia and Buitenzorg in Java, 150 kilometres [921 miles] from the scene of the explosion, the noise resembled artillery fire at close range ${ }^{3}$. The vibrations made the window-panes

[ ${ }^{1}$ See the outline section of Krakatau published in "The Eruption of Krakatoa and subsequent Phenomena" (Report of the Royal Society Committee), p. 6, fig. 4, London, 1S88.]

$\left[{ }^{2}\right.$ For map showing the places at which the somnds of the explosions were heard on Aug. 26, 27, see Rep. Roy. Sre. Pl. XVI.]

[ ${ }^{3}$ 'The most remote place at which sounds were heard is said to be Rodriguez, nearly 3000 miles from Krakatau. Rep. Roy. Soc. p. 79.] 
rattle and shook the houses to such an extent that objects were thrown fiom tables.

During the eruption the volcano covered the whole neighbourhood for a distance of 35 kilometres [22 miles] with glowing stones and hot ashes. Near the centre of activity, on the island of Sebesi, with 2000 inhabitants, villages suffered the fate of Herculaneum and Pompeii. $\Lambda$ dense rain of ashes fell over the whole of South Sumatra, to Benkoelen and Palembang in the north, in West Java beyond Batavia and the residency of Preanger, while the finer dust was spread over a much greater area amomting approximately to 600,000 square kilometres [234,000 square miles]. In a south-westerly direction the rain of ashes extended 1200 kilometres [750 miles], and it is well known that the finest particles mixed with aqueous vapour and suspended in the upper region of the atmosphere were carried round the world and cansed the wonderful twilight effects which were observed everywhere in December 1883 ${ }^{1}$. The total amount of material thrown ont from the craters of Krakatan from May to August 1883 was estimated by Verbeek, after careful calculation, at 18 cubic kilometres [4.4 cubic miles]. As a result of this enormous loss of material the chief crater and adjacent parts of the island were undermined and on the morning of August 27 th the climax was reached: a large portion of the island and of the surromnding sea-floor fell in like an insufficiently supported vault. The sea was drawn after the débris from all sides into a fumnel-like depression and, surging up again over the submerged crater, produced gigantic waves which rose to a height of 40 metres [131 ft.] and, carrying with them blocks of rock which reached 300 cubic metres in bulk, broke repeatedly on the coasts of Java and Sumatra. For a distance of several kilometres inland everything was destroyed; whole villages disappeared and about 30,000 people were drowned. In the shallow Java Sea the waves acquired less force. The low islands in the Bay of Batavia snffered considerable damage and in Tandjong Priok, in the harbour of Batavia, from midday on August 27th for the next 36 hours as many as 18 seismic waves were recorded, the first and highest of which reached a height of more than 2 metres. On the same day large waves were produced in all the harbours of the Indian Ocean where the decper water furnished much more favourable conditions for their transmission. By August 28th the seismic waves had found their way into the North Atlantic Ocean and were recorded at Rochefort, Cherbourg, Havre and other places?

The geological expedition conducted by Verbeek, which under-

[' See Part IV. and Pl. XxxVI., Rep. Roy. Soc. Committee.]

[² See Reprovt Roy. Soc. Com. Part III.] 
took the investigation of the group of islands two months after the eruption, found that enormous geographical changes had occurred (see Sketch-map, Pl. II.). The small island Polish Hat, part of Lang island as well as two-thirds of Krakatan itself, embracing an area of 2285 square kilometres [8\% square miles], had sunk. The line of fiacture passed through the middle of Rakata, the highest peak of which still remained. The face of the mountain from summit to sealevel now formed a steep and almost vertical wall (Plate III.). At the foot of the cliff' and beyond in the new area of sea which occupied the site of the former crowded group of islands, the lead tonched bottom at a depth of 100, 200 and in places 300 metres.

No lava-flows appear to have occurred during the whole period of volcanic activity, but on the other hand the three islands were covered with pumice and layers of ash reaching on an average a thickness of 30 metres and frequently 60 metres [98-196 ft.]. To this extent Verlaten island and Lang island were increased in height: the former had also increased in circumference.

A new marginal belt was formed along the sonth-west to the sonth-east coast of Krakatau, $4 \cdot 6$ square kilometres of land being added to the zone of $10^{\circ} \mathrm{z}$ square kilometres which remained. During the short period of two months after the eruption subaerial denudation had already carved out of the loose strata deep valleys and gorges in some cases with vertical walls from 6 to 8 metres high. In the vieinity of the peak, where the newly formed deposit must have been thimnest, patches of the original rock surface protrnded here and there exposing the blasted and carbonised remains of tree stems. The last remnants of plant-life which had withstood the first outbursts were everywhere destroyed and buried under a thick covering of glowing stones. The islands, which were formerly green, assumed the appearance of a desert of the most desolate type, a desolation, minhabited and in all probability for a considerable period uminhabitable, separated by 19 to 25 kilometres $\left[12-15 \frac{1}{2}\right.$ miles] from the neighbouring and half-destroyed islands of Sebesi and Seboekoe and by 35 to 45 kilometres [22-28 miles] from the nearest points of the Javan and Sumatran coasts. But the first pioneers of plant and animal life soon obtained a footing and to-day, 25 years since the complete destruction of all organic life on the group of islants, these are again covered with a mantle of green, the growth being in places so Inxuriant that it is necessary to cut one's way laboriously through the vegetation. 


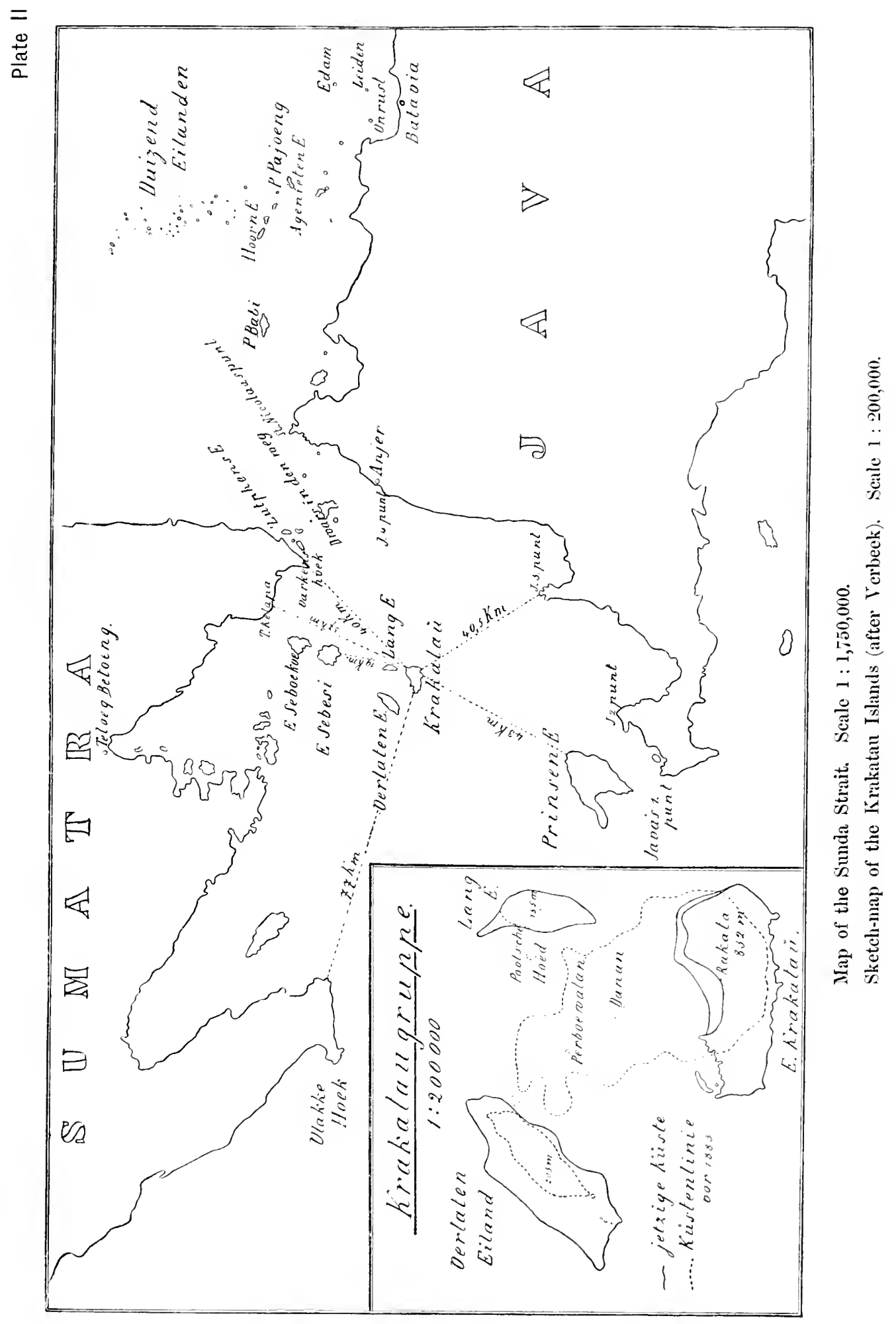





\section{Results of the visits of 1886 and 1897 .}

Dr Melchior Treub, the distinguished and genial Director of the Botanical Institute at Buitenzorg in Java, renrlered a great service to Science by initiating the study of the new Krakatau flora and thus paving the way for further investigations. The botanical explorations, marle on three different occasions, of the islands which were entirely depleted of regetation in 1883 have not only furnished results of general biological interest, but by demonstrating the successive stages in colonisation, they also afford one of the most important contributions towards the solution of the much discussed problem as to the source and history of the introduction of a flora into an island far remored from the mainland. The older literature ${ }^{1}$ concerned with this interesting problem in plant-geography, so far as regards direct observation, deals with the history of colonisation of recently formed coral islands, that is of flat land surfaces, and with the investigation of the means of dispersal of plants from older coral reefs and volcanic islands. On Kuakatau, Trenb2 had an opportunity of studying the more complex problem: how a volcanic island, which has lost the whole of its flora as the result of an eruption, acquires a new vegetation; how, in other words, an island of considerable height suddenly emerging from the sea becomes stocked with plants; and further by what successive stages the new floral elements appear on the island and by what external agencies the colonisation is effected.

The first germs of land-plants are brought by ocem-emrents which carry seeds and fruits, drifting on the surface of the water, to the low-lying beach of emerging coral islands. Some of these seeds on arrival are still cipable of living; they germinate and, provided the conditions are not too unfavourable, continue to grow and constitute the first plants of the island. It has long been known that only a comparatively small proportion of plants are capable of extencling the area of their distribution by this means.

A comparison of island flomes has shown that it is exclusively strand-plants-in the Malay Archipelago there are about 320 specieswhich have seeds and fruits possessing the necessary adaptations for this method of dispersal by ocem-currents, that is which are capable

1 A complete list will be foumd in W. B. Hemsley's "Report on the present state of knowledge of various Insular Floras." Introduction to the first three Parts of the Botany of the Challenger Expedition, Botany, Vol. I. p. 69.

2 M. Treub. "Notiee sur la nouvelle Flore de Krakatau." Annales dn Jardin botunique de Buitenzory, Vol. vir. 1888.

M. Treub. "Over het nieuwe Plantenkleed van Krakatau." Natuurkundig Tijdschrift roor Nederlendsch-Indie, Band 48, 1859. 
of floating for weeks or months on sea-water withont losing the power of germination.

Among the agencies concerned in the colonisation of coral islands the second place may be ascribed to birds which use them as resting places or visit them in search of food. They serve in various ways to enrich island floras. Fruit-eating birds eject seeds which lave passed uninjured through their intestine. In the process of cleaning and preening their plumage birds often rub off small fruits and seeds attached by hooks or other contrivances to their feather's or which are carried with earth or mud on their feet.

Numerous coral islands owe their first and most widely spread plants to ocean-currents and to birds. Spores and seeds of other plants, as extended observations have shown, are introduced by wind and occasionally by other agencies ; these quickly fill up gaps in the vegetation, finding in the substratum already prepared by earlier arrivals, conditions favourable for germination and subsequent development.

In the case of Krakatau, Treub expected to find phenomena analogous to those already referred to as characteristic of the progress of colonisation of recently formed coral islands ${ }^{1}$; he wrote: "Le littoral de l'île se convre de plantes à l'aide des graines amenées par les courants océaniques et par les oiseaux tout comme chez les îles de corail. Les éléments qui composent la flore de cette bande littorale remonteront petit-ì-petit les versants de l'île; cela est possible parceque la plupart de ces plantes, bien que préférant une station saline, croissent vigoureusement encore éloignćes de la plage et ì une assez grande altitude. Cependant, plus la bande végétale originaire de la plage remonte et plus sa marche se ralentira. Finalement ce sera presque uniquement par l'entremise des oiseaux que les parties les plus élevées de l'île se peupleront de plantes. Une fois tonte l'île couverte d'un tapis végétal peu dense encore, le terrain sera peu à peu préparé à recevoir d'antres plantes dont les spores ou les graines sont amenées par le vent on par d'antres causes."

The actual method of plant introduction has, however, proceeded along altogether different lines. In June 1886, when the island was first visited by Treub, the pioneers of a new vegetation were seen from the shore to the peak and he was able to establish the important fact that the re-stocking of the beach and of the interior, including the slopes of the cone, had been effected simultaneously, though in different ways and for the most part by different plants. It was shown that blue-green Algae were the first colonists on the pumice and volcanic ash as also on the exposed blocks of rock in

1 Treub, loc. cit. p. 216. 
the ravines on the momtain slopes. Investigations made during subsequent expeditions demonstrated the association of Diatoms and Bacteria with the blue-green Algae. The dark green gelatinons layer with which these minute, self-sufficient, and doubtless windborne organisms covered the pumice and ash formed a favourable nidus for the germination of the spores of mosses and ferns and of the seeds of such phanerogams as are adapted by their small size and weight to dispersal by air-eurrents. An especially characteristic feature of the first stage of colonisation was the preponderance of ferns, which were represented by 11 species widely spread in the Indo-Malay Archipelago; only two of these, however, belong to the strand-flora of the islands.

In addition to cryptogams phanerogams were also met with on the island in 1886, thongh in comparison with ferns they were at first represented by a relatively small number of species and individuals. In the Drift-zone of the beach, Trenb found seedlings of nine species of phanerogamous plants, the seeds of which had germinated on being washed up by the sea, also the fruits and seeds of seven other phanerogams which, like the former, belong to the strand vegetation characteristic of the Nalay Archipelago. In the interior and on the slopes of Rakata, the number of phanerogams amounted to eight species, two of which were identical with those found on the beach. The remaining six species, four Compositae and two grasses, plants with light fruits-some of which were provided with special adaptations to wind-dispersal-were obviously, like the minute spores of the cryptogams, transported by air-currents from the neighbouring islands to the new land surface of Krakatan. Plants introduced by animals or man were not found on the uninhabited and barely accessible island.

The problem of the colonisation or re-stocking of a high volcanie island situated far from the mainland was thus solved in a remarkable manner by Trenb's researehes. It was demonstrated that the elements of the strand-flora played a very subordinate part in the composition of the new flora, a result entirely contrary to what one would expect from the analogy of coral islands where these elements are the first colonists. The flora of the interior of the island had dereloped not only independently of the strand-flora but also with much greater rapidity : the number of species was greater and in the case of certain ferns the number of plants was sufficiently large to constitute a characteristic feature in the general facies of the vegetation. A few phaneroganns were first met with as isolated plants among the ferns both on the mountain and on the beach.

To follow the gradual changes in this new plant-world of the island, poor in species and brought together in so remarkable a 
manner, would clearly have been of the greatest interest. A thorough investigation of the group of islands planned by Treub for the following years had unfortunately to be given up, and it was not until ten years later, in March 1897, that the project was carried out, when Treub, Penzig'1, Raciborski, Boerlage, and Clautriau took part in a second exploration of Krakatau.

During the interval of ten and a half years between the first and second expeditions there had been a considerable increase in the number of species in both coast and inland floras. In 1897 the total number of species found on Krakatan and on the other islands visited by the expedition, Verlaten and Lang islands, which in 1886 were entirely destitute of vegetation, amounted to 62 species of vascular plants, including 50 phanerogams and 12 vascular cryptogams, in addition to the seeds and firuits of 26 phanerogamons plants washed up ou the beach. The assemblage of plants had become denser and the ground was in places completely covered; the development of characteristic plant-associations (formations) had begun. On all three islands the Pes-caprae formation or association formed a dominant feature on the beach. Mangrove plants were unrepresented and the first sign of a strand-forest was noticed only on Verlaten island.

Further inland the regetation constituted a kind of grasssteppe characterised by grasses, occasionally reaching the height of a man, which in several places formed a thick jungle. Lower grasses grew on the hills and ridges in association with numerous ferns and sparse phanerogans. As in 1886 ferns largely predominated on the rock surfaces. Shrubs were poorly represented and trees were very rare.

Of the 53 phanerogams found in 1897, Penzig estimates that 32 species $(60 \% 39 \%)$ had reached the islands by ocean-currents, 17 species $(32.07 \%)$ by wind-agency, and only $4(7.54 \%)$ had been transported by fruit-eating animals or by man.

\section{The expedition of April 24-27, 1906, to the Sunda Strait region and to Krakatau.}

In 1905 another visit was paid to Krakatan, in which Th. Valeton, M. Golenkin and other botanists took part. The results of this expedition have not been published.

During my residence at Buitenzorg I made application, in company

1 Penzig, O. "Die Fortschritte der Flora des Krakatau." Annales du Jardin botanique de Buitenzorg, 1902. Vol. III. sér. 2, pp. 92--113. 
with C. A. Backer", the author of a comprehensive "Flora of Batavia" which is now in the press, to Professor Trenb to organise another expedition for the investigation of the Krakatau flora. As the result of his kind co-operation the anthorities placed at our disposal a small coasting steamer which was then on the point of visiting certain places on the coast of the Sunda Strait to relieve the lighthouse keepers. The excursion was to last four days and the departure was fixed for April 24 th. Unfortunately Professor Treub was prevented by illness from accompanying ns, but we were joined by two botanists who happened to be studying in the Buitenzorg botanic garden, Dr A. A. Pulle from Holland and Prof. D. H. Campbell of California.

The plants collected by C. A. Backer and Dr A. A. Pulle in the comse of our Krakatan excursion, on the island and at different localities on the coasts, were determined by the former, who was kind enongh to undertake the revision and to some extent the identification of the vascular plants collected by myself. The list of phanerogams and vascular cryptogams which we collected, communicated to me by C. A. Backer, will appear either in Verslag van's Lands Plantentuin te Buitensorg or in the Mededeclingen nit's Lands Plantentuin te Buitensorg. As a matter of convenience I have arranged the plants in the following lists according to families, including the names of some species of widely distributed and well known plants of which, though no specimens were collected, records were made in my notes written on the spot.

Since the appearance of the German edition of this accomt Dr Pulle ${ }^{2}$ and Prof. Camplell ${ }^{3}$ have published some of the results of their own observations, the former in a detailed abstract of this work and the latter in a paper on the distribution of liverworts.

\section{Vegetation and flore of the coral island Edam.}

In beantiful weather on the morning of April 24 th, 1906, the "Snip" (Snipe) left the harbour of Tandjong Priok to steer a western conrse among the numerous small coral islands scattered along the northwest coast of Java. Our first objective was the island of Edam, barely 12 kilometres distant, which like Onrust, Leyden and other small islands ontside the harbour of Batavia, was formerly inhabited. Today the European keepers of the large lighthouse and their Javan

${ }^{1}$ Backer, C. A. Flora ean Butavia. Deel I. Dicotyledones Dialypetalae. Batavia, 1907.

" Pulle, A. A. "De nienwe flora van Krakatau." Overgedrukt uit De indische Merkur, April 21, 1908.

3 Campbell, D. H. "On the Distribution of the Hepaticac and its significance." New Phytologist, Vol. vi. p. 203, 1907. 
servants are the only inlabitants. The inhospitable islands with their ruined houses and grass-grown streets are the home of a dangerous malaria. Swarms of gnats attack the inhabitants at night and are troublesome even in the daytime as one wanders through the thickets. The strong smell from decaying plants and marine animals, the moisture-laden air and almost intolerable heat bear eloquent testimony, even after a short visit, to the injurious consequences which are bound to follow a longer residence on one of these islands. The lighthouse keepers, in spite of a comparatively high seale of payment, remain a short time only and return with their families after $1-3$ months service on a long furlough to the healthier climate of Batavia. The island is encircled by surf; at the narrow entrance our boat bumped against the small stone pier which has been built on the coral reef for the convenience of landing. In the course of the repeated journeys of the boat necessary to land provisions for the small number of inhabitants, also the petroleun for the lighthouse lamp, and the postbags and monthly wages, we had time to explore the island. After traversing streets overgrown with tall grass, and passing through a small vegetable garden and a plantation of coconut palms to a waste piece of formerly cultivated land, we reached the interior and the opposite beach, where broad strips of the original vegetation still remain.

On the way we found several specimens of a large arborescent euphorbiaceous plant, Phyllanthus Emblica, draped with tangled skeins and thick coils of yellowish green and brown threads. All the branches and twigs are covered by a dense network of similar threads and the same felted mass hangs from the grasses and herbaceous plants growing under the trees. These long threads are the stems of a climbing parasitic species, Cassytha filiformis, which bears a striking resemblance in habit to our native species of Cuscuta, though it is a member of the family Lauraceae, which has no close affinity with the Convolvulaceae to which Cuscut $u$ belongs. The vegetative system, like that of Cuscuta, consists of branched climbing shoots bearing adventitious roots modified as haustorial organs which attach themselves to the tissues of the hosts. The true roots have disappeared and the leaves are reduced to small inconspicuous and finctionless scales. The reproductive shoots, on the other hand, both flowers and fruits, are abundantly developed and occur in large spherical or elongated masses. The white fruits are in marked contrast to the tangled felt of host and parasite; birds eagerly eat them and by ejecting the seeds contribute in an important degree to the dispersal of this interesting member of the strand-flora, which is not as yet so completely adapted to a parasitic life as Cuscuta. It has the power 
of independent assimilation and grows impartially on nearly all the plants of the strand vegetation. The interior of the island is occupied by a thicket of various trees and shrubs. With Pleyllenthes Emblicu and Phyllanthus simplex occurs Aealyphe indica, another representative of the family Euphorbiaceae which is rich in halophilous species; also the leguminous plants, Banhinic Blaneoi and Leucuence glanca, the young fruits and ripe seeds of which are eaten by natives in the Arehipelago as a relish with their meals of rice. The ground is covered with herbaceous plants, bushes and shrubs, principally of the families Gramineac, Cyperaceae, Compositac, Labiatae, and Leguninosae. Our guide warned us to be careful in entering the bush, as in addition to the large but harmless snake, P!ython reticularis, which reaches a length of 3 to 4 metres, some smaller poisonous species are also met with.

The sonth coast of the island is flat and sandy. A broad belt is covered with a low and almost shrubless regetation, of which the two characteristic plants are Spinifex squerrosus and Ipomaen Pescaprae. Each of these is admirably adapted to a strand habitat. Spinifex squarrosus is a stiff bluish glistening grass with tufts of rounded and sharply pointed leaves bound together by tough rumners hidden in the sand. The low form of growth, the anchoring of the stems in the loose sand by deep roots, are adaptations to a habitat exposed to frequent and strong winds.

The conditions, which are unfavourable for vegetative development, have been utilised in a remarkable manner by Spinifex for the dispersal of its fruits. The firuiting shoots are very large and completely spherical. The spikelets are crowded in the centre of a ball as large as a man's head at the base of long stiff axes which spread out on all sides like bristles (Pl. VII., fig. 10). The ripe firuiting shoots fall off and are rolled as light balls ${ }^{1}$ over the sand until they attach themselves to other plants or become the sport of the waves. Some of these small finits are detached during the process, while others remain fixed to the shoot for a longer period and with it are carried by the wind over wide stretches of the beach or transported by currents to other islands. Single shrubs and taller herbaceons plants appear above the groups of Spinifex squervosus, Ipomace Pes-capree, and Ipomaca Pes-tigridis; of these the most striking are the abundant and handsome plants of Tacea pimuetifiele with its two to four large umbrella-like leaves and strong reproductive shoots.

${ }^{1}$ Goebel, K. Pfanzenbiologische Schilderungen, Bd. I. 1889, p. 135. The peculiar method of dispersal of these fruiting branches is well known to the Javanese. The Malay name for the plant is djuekoet lari lari, that is "running grass" (Miquel, loc. cit. III. p. 474). 
On the north coast trees and shrubs extend to the water's edge or even into the water. We found in Edam a mangrove belt poor in species, an association not often met with on small coral islands. It consists chiefly of species of Rhizophoraceae, Rhisophora conjugata, Brugiera gymonorhisa, Brugiera caryophylloidles, with two members of the Lythraceae, Someratia alba and Pemphis acidula.

A considerable area of the interior, formerly under cultivation, is now covered with grasses, especially with Imperata armedinacea, which exceeds the height of a man. By the sides of the paths we found several specimens of the common blne-flowered Javan verbenaceons species Stachytarphete indica and Lantane Camara, the inflorescences of which glow with different shades of yellow and red; also numerous Compositae which, like Bidens pilosns, Vermonice einerea, and Wedelin glabrate, occur in all the warmer regions of the world, or, like Tridlex mocumbens and particularly Synedrella nodiflora, have spread from the New World over the tropics of the Old. The amount of material collected during our excursion, which lasted barely two hours, was remarkable. It consisted of 75 phanerogams and 2 vascular cryptogams. On the coral reef $I$ was able to collect 12 different green algae, the commonest being species of Caulerpa, Udoter, and Halimeda; also some red and brown sea-weeds.

As the composition of the flora on the neighbouring islands is probably similar to that of Edam and as our collection is of interest from the point of view of comparison with the floras of other coral islands such as Schimper ${ }^{1}$ and Guppy ${ }^{2}$ have described, the list of the species obtained on Edam is appended:

ANGIOSPERMAE :

Fam. Compositce :

Bidens pilosus L.

†Eclipta alba Hassk.

Synedrella nodiflora Gaertn.

Tridax procumbens L.

Vernonia cinerea (L.) Less.

* Wedelia glabrata B. et $\mathrm{H}$.

Fam. Goodeniaceae: +Scaevola Koenigii Vahl.

Fam. Rubiaceae: tGuettarda speciosa L.

† Morinda citrifolia $\mathrm{L}$.

* Oldenlandia nmbellata L.

\footnotetext{
${ }^{1}$ Sehimper, A. F. W. Die indomalayische Strandfora. Jena, 1891, pp. 185188.

"Guppy, H. B. The dispersal of Plants, as illustrated by the flora of the Keeling or Cocos Islands. [See also Guppy, Observations of a Naturalist in the Pacific between 1896 and 1899. Vol. II., P'lant Dispersal. London, 1906.]
} 
Fam. Labiatae: * Anisomeles albiflora Miq.

Leucas linifolia (Roth) Spreng.

* Ocimmm basilicum $\mathrm{L}$.

Fam. Terbcuacece: †Clerodendron inerme Gaertner

Lantana Camara L.

+Premma foetida Reinw.

Stachytarpheta indica Vahl.

+Vitex Negundo I.

Fam. Borraginacear: +Cordia subeordata Lam.

Fam. Comrolinlaceae: Calonyction aspermm Chois.

+Ipomaea Pes-caprae Sw. [= I. biloba

* Ipomaea Pes-tigridis L.

Fam. Asclcpiadareac: †Hoya spec.

Fan. Myrtaceac: *Engenia Jambolana Lam. (?)

Fan. Rhizophorareae: +Brugiera caryophylloides Bl.

+Brugiera gymmorhiza Lam.

+Rlizophora conjugata L.

Fam. Lythraceae: +Pemplis acidula Forst.

+Somneratia alba Smith

Fam. Passifloraceae:

Fam. Sterculiaceae:

Fam. Malvaceae:

* Passiflora foetida I.

Fan. ritaceae:

Sterenlia foetida $\mathrm{L}$.

Fam. Rhamnaceae:

†'Thespesia populnea Corr.

* Vitis trifolia L.

+Colıbrina asiatica Brongn.

* Sageretia oppositifolia Brongn.

†Zizyphus Iujuba Lam.

Fan. Sapindaceae: * Allophyllus Cobbe Bl.

Schleichera trijuga Willd.

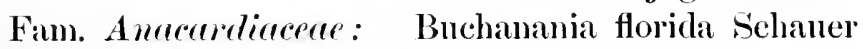

Fam. Euphorbiaceac: *Acalyphe indiea L.

+Euphorbia Atoto Forst.

* Phyllanthus Emblica L.

* Phyllanthus simplex Miill. Arg.

Ricinns communis L.

Fam. Meliaceae: †Carapa molnecensis Lam.

Fan. Leguminosae: tAbrus precatorius I.

Baulinia Blancoi Baker

+Canavalia obtusifolia D.C.

* Crotolaria Saltiana Andr.

†Desmodimm triflor'm D.C.

* Indigofera tinctoria L.

Lencaena glanca Bentl.

* Zornia diphylla Pers. 
Fam. Lauraceae: †Cassytha filiformis I.

† Hernandia peltata Meisn.

Fam. Portulacuceae: * Portulacea australis Endl.

+Portulacca oleracea L.

Fam. Aisocecere: tSesuvium portulacastrum Willd.

Fam. Nycteginacece: †Boerhavia repanda Willd.

Fam. Amorontaceae: *Aerua lanata (L.) Juss.

†Achyranthes aspera Lam.

Fam. Taceacece: †Tacea pimnatifida Forst.

- Fam. Palmae: tCocos nueifera $\mathrm{L}_{\text {. }}$

Fam. Cyperccece: †Cyperus pennatus Lam.

* Cyperus hyalinus Vahl.

* Fimbristylis spathacea Roth

Fam. Grominecte: Andropogon contortus L. Eleusine aegyptiaca Desv. Eragrostis tenella R. et Sch. Imperata arundinacea Cyr. Paspalum distichum L.

Paspalum sangninale Lamk. †Spinifex squarrosus $\mathrm{I}$.

tThuarea sarmentosa Per's.

PTERIDOPhyta :

+Zoysia pungens Willd.

Fam. Polyporliacene: +Polypodium quercifolimm L.

Polypodium acrostichoides Forst.

Drymoglossium spec.

Not less than 36 of the plants (indicated in the list by $\dagger$ ) are inelnded in Sehimper's list ${ }^{1}$ of the Indo-Malayan strand-flora as typical halophytes, and 19 additional species (distinguished by *) belong to genera which include characteristic strand species. In the case of the majority of these plants there is no doubt that the seeds and fruits are easily distributed by ocean-currents. $\Lambda$ smaller number, in view of the comparatively short distance between Edam and Java, probably owe their introduction also to wind-agency. These are: Erlipta alba, Wedelia glabrata, Cyperus hyalinus, Fimbristylis spethecea, Polypodinem quercifolinm, or possibly introduced by birds: Scaerola Koenigii, Morimla citrifolia, Clerodentron inerme, Premen fortida, Vitex Negnendo, Allophyllus Cobbe, Cassytha filiformis.

In addition to the numerous representatives of the Indo-Malayan strand-flora, a large number of inland plants have become established 
on Edam. Some of these, as Sterculia foetida, Plybllanthus Emblica, Phyllanthus simplex, Lencaena glanea, Schleichera trijuga, Ricinus communis, and Indigoferce tinctoriu, have been introduced by man; others, such as Symedrella nodiffora, Anisomeles albiftora, Lenecrs linifolia, Lantana Cemara, and Stachytarpheta indica, owe their introduction partly to man and possibly to some extent to birds. The two ferns, Polyporlinm acrostichoides and Drymoglossum sp., some of the Composites, Bidlens pilosus, Tridux procumbens, and V'rmonice cincren, the fruits of the grasses Audropogom contortus, Elcusine aegyptiana, Evagrost is tevella, Imperata arumelinacea, Paspatum distichum, and Paspatum sangninale were carried by wind from the neighbouring mainland of Java. The flora of the other formerly inhabited islands off the harbour of Batavia, like that of Edam, is probably composed of typical strand-plants and introduced inland species; while in the case of the more distant islands, like that of the Thousand Islands, some of which were visited by Schimper, the whole flora has been built up of species from the strand-formation of Java.

The next stage of our voyage lay in the region of the Thousand Islands. Our steamer touched at the island of Pajoeng, 2.5 kilometres

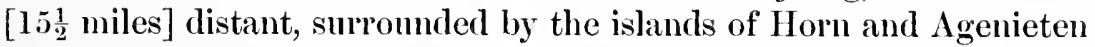
and situated about 20 kilometres from the coast of Java. On the most easterly of the three islands, which is encircled by a coral reef 100 metres [328 ft.] wide, there is a lighthouse and some dwellinghouses. A low mangrove swamp, which reaches into the water, stretches along the coast in an easterly direction; towards the west, the dark Barringtonia forest, diversified by grey-green Casuarinas, forms a backgromnd to the sandy shore overgrown with Ipomaen, Spinifex, and Vigne lutere, which afforded a rich harvest of large and many coloured shells.

\section{On the berach at Vlalile Hoel: (Simatra).}

Before nightfall we reached Poeloe Babi, a larger island with a wooded coast, and during the night the steamer passed between the islands of Sebesi and Seboekoe towards the coast of Sumatra. On the following morning before sumrise the "Snip" lay off the lighthousestation Vlakke Hoek on the southern point of the most westerly of the three Sonthern Sumatran peninsulas. The iron tower, 60 metres in height, rose above the sombre forest fringing the coast line. When the flood of August 27th, 1883, swept over the flat beach, 103 kilometres [ 64 miles] distant from Krakatau, to a depth of 15 metres, the tower withstood the force of the waves; the neighbouring structures of stone and iron were on the other hand destroyed, 
beams and pieces of iron being found afterwards at a considerable distance among the wreckage of the overthrown trees.

Even to-day the vegetation of Vlakke Hoek still bears traces of the devastation which occurred 25 years ago. A new forest of coconut palms has sprung up in the neighbourhood of the small settlement. Part of the devastated cultivated land is covered with Imperata armulinacen, the Alang-Alang grass widely distributed in the Archipelago, which everywhere spreads as a thick carpet over bare patches of forest and neglected fields and slowly retreats before new forest growth.

The beach of Vlakke Hoek (Tandjong Rata of the natives) is flat and sandy. Towards the east the shore is fringed by a large rectangular coral reef, on the outer edge of which the waves break into foam. Unfortmately the rising tide interfered with algological investigations which, judging by the interesting finds on the beach, would probably have yielded a rich harvest.

There is no mangrove vegetation in the neighbourhood of Tandjong Rata. Spinifex and Barringtonia formations alternate with one another. In many places the waves rush over the fine sand to the half-exposed network of roots of the ontermost trees of the strandforest. Where the forest is further from the coast larger and smaller patches are covered with Spinifex squarrosus and Ipomece Pescaproe; shrnbs of Hibiscus tiliacens are met with, also Hernamlia peltata, Colubrina asiatica, and Toumefortia argentea with its shimmering grey-green leaves. Below the low trees and shrubs of the Leguminous species Desmorlinm umbellatum, Pongamia glabra, Sophora tomentosa, one finds the beautiful flowering grass Thuarea sarmentosa; also other members of the Gramineae, such as Zoysia pungens and Oplismenus compositus, the Cyperaceous species Fimbristylis spathacea, some ferns with singly pimnate leaves, Nephrolepis hirsutula and large clumps of Acrostichum aureum. The parasite Cassytha filiformis occurs on a variety of shrubs and herbaceons plants. Scaevola Koenigii, a Goodeniaceous species with tufts of fleshy light green leaves terminating long branches, grows in abundance, also crowded young plants of Terminalia Catapma characterised by their formal habit. Groups of Barringtomia speciosa present a strange appearance. Nmmerous trees lie partly uprooted with the stem on the ground, the crown half-erect. These are veterans overthrown by the seismic wave of 1883 and which have preserved themselves in the midst of the subsequent growth: their thick stems and branches are overgrown by a thick mantle of small epiphytes, lichens, liverworts, and mosses, in contrast to the other strand-plants which are destitute of epiphytic species. Bushes of 
Crimm asiatieum, a handsome amaryllidaceous plant with long leaves and a wealth of white flowers, grow in the clearings. Tall Pandanus trees with dense crowns and sharp-pointed leaves present a fantastic appearance on the beach. The lower conically pointed ends of their stems are supported by prop-roots which spring from them at a lieight of 1-2 metres above the surface of the ground and spread obliquely ontwards to the soil, while some of the younger adventitious roots, $1-5 \mathrm{~cm}$. in diameter, have not yet reached the ground. The tissue of these younger roots is exceedingly soft and full of water (peripheral layers of cork prevent excessive loss of water) and their bluntly conical apices are protected against injury and drought by a massive root-cap composed of several thin layers of tissue. Two hours only were available for an exploration of the neighbourhood of the lighthouse. At nine o'elock we returned with our spoil to the boat. I append a list of the vascular plants collected (38 phanerogams, 4 ferns):

Fam. Compositae:

Fam. Goodeniaceae:

Fam. Rubiaceae:

Fam. Acanthecene:

Fam. Verbenaceae :

Fam. Borraginaeeae:

Fan. Comrolevlaceae:

Fam. Myrtacece :

Fam. Combretaceae:

Fam. Guttiferae:

Fam. Sterculicacea :

Fam. Malvaceae:

Fam. Vitaceae:

Fam. Rhammaceae:

Fam. Sapindaceae:

Fam. Legnminosae:

Fam. Lauraceas:
*Wedelia glabrata B. et H.

† Seaevola Koenigii Vahl.

†Guettarda speciosa L.

* Ixora paludosa Boerlage

* Eranthemum diversifolium Miq.

Lantana Camara L.

†Premna foetida Reinw.

Stachytarpheta indiea Vahl.

†Tournefortia argentea $\mathrm{L}$.

†Ipomaea Pes-caprae Sw.

† Barringtonia speciosa Forst.

* Eugenia formosa Wall.

†Terminalia Catappa L.

†Calophyllum Inophyllum L.

* Pterospermum acerifolium Willd.

$\dagger$ Hibiscus tiliaceus L.

*Vitis lanceolaris Wall.

†Colubrina asiatica Brongn.

*Allophyllus Cobbe Bl.

Aphania montana Bl.

†Dodonaea viseosa $\mathrm{L}$.

* Crotalaria Saltiana Andr.

†Desmodium umbellatum D.C.

†Pongamia glabra Vent.

†Sophora tomentosa $\mathrm{L}$.

†Cassytha filiformis $L$.

†Hernandia peltata Meisn. 
Fam. Moraceae: *Ficus Leucantatoma Poir.

Fam. Casuarinaceae: †Casuarina equisetifolia Forst.

Fam. Amaryllidaceae: fCrinmm asiaticum L.

Fam. Flrgellariaceae: †Flagellaria indica L.

Fam. Cyperaceae: *Fimbristylis spathacea Roth

Fam. Gramineae: Imperata arundinacea Cyrill.

Oplismenus compositus Beauv.

†Spinifex squarrosus L.

†Thuarea sarmentosa Pers.

†Zoysia pungens Willd.

Fam. Pandanacerce: *Pandanus spec.

Fam. Polypodiaceae: †Acrostichum aureum L.

Asplenum nidus L.

Nephrolepis hirsutula Presl

Lygodium dichotomum Swartz

The flora of Tandjong Rata, as the foregoing list shows, consists for the most part of typical halophytes. Not less than 22 of the 38 phanerogams are included in Schimper's list of the Indo-Malayan strand-flora, and 11 other plants, belonging to genera which include species of Indo-Malayan strand-plants, may probably be reckoned as additional members of the strand-flora. Only eight of the vascular plants enmmerated, three of which are ferns, have their chief centre of distribution in the interior.

The old Barringtonia stems supported an epiphytic flora consisting of small mosses, liverworts, and lichens. The determination of these and the other cryptogams collected in the comse of the Krakatan excursion was kindly undertaken by Prof. V. F. Brotherus (mosses), Prof. V. Schiffner (liverworts), Prof. A. Zahlbruckner (lichens), Prof. P. Lindan (fungi), and Dr E. De Kruyff (bacteria). I take this opportunity of expressing my cordial thanks to these botanists.

The small epiphytes on the Barringtonias of Vlakke Hoek include:

Musci : Trichosteleum hamatum Dz. et Mb.

Calymperes Hampei Dz. et Mb.

Hyophila Micholitzii Broth.

HePaticae: Cheilolejemea parvula Schiffin. n. sp.

Microlejemea cucullata (Reinw., Bl. et Nees) St.

Acrolejemea integribractea Schifti.

Lopholejemnea spec.

Lichenes: Parmelia perforata Ach.

Parmelia relicina $\mathrm{Fr}$.

Physcia spec. 


\section{In the Sunda Strait: uinds and ocean-currents.}

On the same day we had an opportunity of botanising on another larely visited locality of the Javan coast. The "Snip" steamed across the Sunda Strait at its broadest western part to the most westerly promontory of Java, "Java's First Point." ln a strong wind and rough sea this passage in a steamer of only 300 tons was the reverse of pleasant and put the passenger's to a severe test. The sky fortunately remained partially overcast and the temperature was bearable. During the night the thermometer sank to $27^{\circ} \mathrm{C}$. and at midday in the shade registered only $29 \frac{1}{2}^{\circ} \mathrm{C}$. The preparation of the algae, which we had collected, and the work of drying the plants on the narrow deck of the rolling and pitching boat were carried out under difficulties. Even Sahib, my industrious servant and a seasoned traveller, at last found his accustomed duties no longer "enak" (palatable), and we followed the example of the others who had long ago stretched themselves on chairs and forms in their endeavours to resist with more or less success the effects of the pitching and tossing of the ship.

We were now (the Krakatau group lies approximately $105^{\circ} 25^{\prime}$ east long. and $6^{\circ} 10^{\prime}$ sonth lat.) in the middle of the equatorial belt of the monsoon distmbances both in the atmosphere and the water. A strong sonth-east monsoon drove the waves directly against us. As the boat steered her course against wind and waves towards the next port of call, the captain, Mr $\mathrm{Nix}$, who had for many year's made three voyages a month in his small coasting steamer in the Sunda Strait, visiting twenty-one lighthouse-stations on the north coast of Jara and on the neighbouring coasts of Sumatra and Borneo, courteously gave us information as to the winds and currents in the Java Sea and especially in the Sunda Strait. The following details in regard to the air-and sea-curents, which are of the greatest importance from the point of view of the history of plant-colonisation of the Krakatan islands, are based in part on information supplied by Mr Nix and are extencled and confirmed from data published in the sailinghandbook of the German Admiralty ${ }^{1}$ and firom other sources?

The south-east monsoon begins, in the wider regions of the Sunda Strait, on the north and south coasts of Java and in Sonth Sumatra,

1 Nemmayer, G. (Divehtion der antsrhen Seewarte.) Segelhandburh fïr den indischen Ozean. Hamburg, 1892.

¿ Neumayer, G. Anleitum zu wissenschuftlichen Berbachungen auf Reisen. III. Aufl. 1906.

Hamn, J. Handluch der Klimalologie. II. Bd. Stuttgart, 1897.

Boguslawski, G. v., and Krümmel. Hundluch der. Ozeanographie. I. Bd. 1884. II. Bd. 1898 . 
during the month of April; during May it increases in force, reaching its maximum from June to September. The direction of the wind does not remain constant during this period but oscillates principally between south-east and east. The high steep coasts of Java, which extend in a north-westerly direction elose to Sumatra and considerably reduce the breadth of the strait, frequently screen the strait and Sumatra from the south-east monsoon and a westerly or south-westerly wind takes its place. The sonth-east monsoon brings a fine season with prevailing dly weather and comparatively light winds. At the period of its maximum force, especially in July and August, the average strength of the wind reaches 3 degrees Beaufort $(5: 5$ met. per second); stronger winds of 6 to 7 degrees Beaufort (135 to $16: 5$ met. per second) are rare in the Sunda Strait area and in the more northerly region to which the data given in the following tables ${ }^{1}$ refer.

The change of monsoon occurs between September and November; it is introduced by the oceurrence of sontherly and westerly winds. The season of the typical north-west monsoon (which is the northeast monsoon deflected by the earth's rotation after crossing the equator) begins in November and lasts until March. This brings bad weather; the rainfall increases in amount and reaches its maximmm in January and February. The direction of the wind (table, p. 22) oscillates from west to north-north-west: its average force being approximately that of the south-east monsoon, about 3 degrees Beaufort. In the ship's log an intensity of $1-3$ occurs frequently ; more rarely, for a period of several days, 5-6 and exceptionally an intensity of $z$ is reeorded (see the accompanying table). At the end of March or in April there is another change of monsoon. There is no prevailing direction for the winds of this period (table, p. 22): winds blowing irregularly from all points of the compass alternate with eahms, sudden gusts of wind and eyclones. At all seasons the

1 Segelhandbuch fiir den indischen Ozean, p. 56. The seales for wind-velocities most eommonly nsed are the Beanfort scale of twelve divisions $(0=$ calm, $12=$ hurricane) and the six- and ten-division seales derived from it. According to the most recent researches (IIann, J., Lehwbuch der Meteorologie, Leipzig, 1901, pp. 376, 377) the following wind-velocities correspond, on an average, to the following values for wind-intensity according to the twelve-division Beanfort scale :

Beaufort intensities

(estimated):

A verage velocity in

metres per second

(after Köppen): $\quad \begin{array}{llllllllllll}1 \cdot 7 & 3 \cdot 1 & 4 \cdot 8 & 6 \cdot 7 & 9 \cdot 8 & 10 \cdot 7 & 12 \cdot 9 & 15 \cdot 4 & 18 \cdot 0 & 21 \cdot 0 & 26 & 40-50 .\end{array}$

On rednetion to the 10-division seale nsed above :

Fistimated intensity (0-10 Beaufort): $1 \begin{array}{llllllllll}1 & 2 & 3 & 4 & 5 & 6 & 7 & 8 & 9 & 10\end{array}$ $\begin{array}{lllllllllll}\text { metres per second : } & 2 & 3.5 & 5.5 & 8 & 10.5 & 13.5 & 16.5 & 22.5 & 28 & 30\end{array}$ 
Frequency of the different wind-intensities (Beaufort) in the Java Sea region.

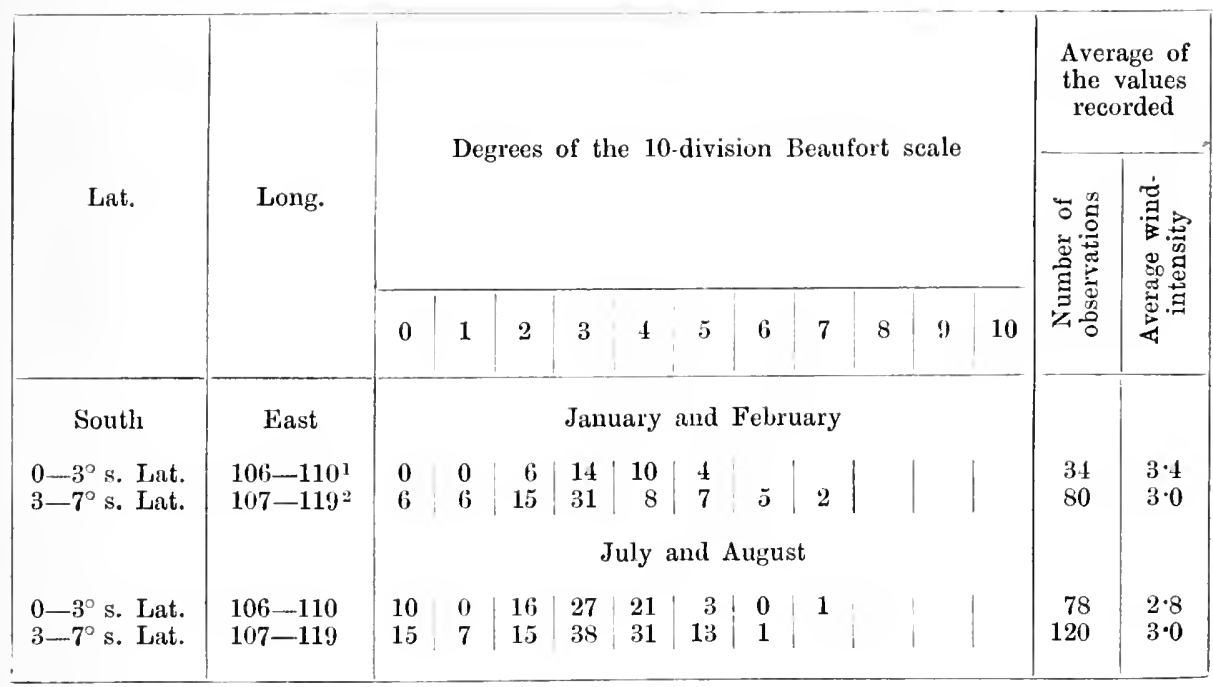

1 Karima Strait between the west coast of Borneo and the east coast of Billiton.

: Java Sea north of Sunda Strait.

direction of the wind may change every day and it may happen that a sontherly wind in the forenoon may shift to the north in the afternoon, with a short spell of calm between.

In addition to the monsoons, storms, of which the lower limit of velocity reaches 17 to 23 metres a second, are not uncommon. During a hurricane the velocity rises to 30 or even to 60 metres a second. Of shorter duration and affecting a smaller area are the squalls, sudden gusty winds, which occur on the momntainous coasts of South-east Sumatra and West Java, as in other regions of the Indian Ocean, especially in the monsoon period, with greatest frequency from February to April. The currents in the Sunda Strait are dependent on the winds. They are, however, of the nature of periodic currents. The direction of the current changes daily and during 24 hours there is only one change; the northerly current brings high tide and the southerly current low tide. The influence of the prevailing wind is generally shown by the fact that during the south-east monsoon the ebb-current flowing towards the sonth-south-west is stronger both in duration and in intensity, while during the prevalence of the west monsoon on the other hand the flood-current rumning towards the north-north-east prevails.

During the east monsoon, fiom May to October, the tide flows strongly for 18 hours continuously towards the south-west, during the next 6 hours with less force towards the north-east, or there may be a 
Percentage frequency of the winds in the sunda Strait district.

$\left(0-10^{\circ}\right.$ S. Lat. and $100-105^{\circ}$ E. Long. $)$

\begin{tabular}{|c|c|c|c|c|c|c|c|c|c|c|c|c|c|c|c|c|c|c|c|}
\hline Month & Latitude & Z & 至 & 岳 & 空 & 쇠 & $\begin{array}{l}\text { 空 } \\
02 \\
\text { 至 }\end{array}$ & 묑 & $\begin{array}{l}\text { II } \\
\text { V2 } \\
\text { W }\end{array}$ & $\Omega$ & 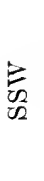 & $E_{n}$ & $\begin{array}{c}E \\
E \\
E\end{array}$ & $E$ & 学 & 学 & 党 & 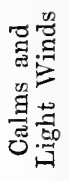 & 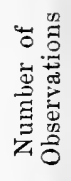 \\
\hline Jan. & $\begin{array}{l}0^{\circ}-5^{\circ} \mathrm{S} \\
5^{\circ}-10^{\circ} \mathrm{S}\end{array}$ & $\begin{array}{r}20 \\
4\end{array}$ & $\begin{array}{r}4 \\
-\end{array}$ & $\begin{array}{r}4 \\
-\end{array}$ & - & - & - & - & - & - & $\begin{array}{r}8 \\
-\end{array}$ & $\begin{array}{l}8 \\
2\end{array}$ & $\overline{16}$ & $\begin{array}{r}4 \\
24 \\
\end{array}$ & $\begin{array}{l}20 \\
15\end{array}$ & $\begin{array}{r}16 \\
22 \\
\end{array}$ & $\begin{array}{l}16 \\
17\end{array}$ & $\begin{array}{r}61 \\
5\end{array}$ & $\begin{array}{l}65 \\
57\end{array}$ \\
\hline Feb. & $\begin{array}{l}0^{\circ}-5^{\circ} \mathrm{S} \\
5^{\circ}-10^{\circ} \mathrm{S}\end{array}$ & $\begin{array}{r}2 \\
-\end{array}$ & $\begin{array}{r}2 \\
-\end{array}$ & - & - & - & - & $\begin{array}{r}2 \\
-\end{array}$ & - & - & - & $\begin{array}{l}3 \\
2\end{array}$ & $\begin{array}{r}3 \\
11\end{array}$ & $\begin{array}{r}3 \\
36 \\
\end{array}$ & $\begin{array}{l}20 \\
19\end{array}$ & $\frac{52}{24}$ & $\begin{array}{r}13 \\
4\end{array}$ & $\begin{array}{l}40 \\
38\end{array}$ & $\begin{array}{l}70 \\
86\end{array}$ \\
\hline March & $\begin{array}{l}0^{\circ}-5^{\circ} \mathrm{S} \\
5^{\circ}-10^{\circ} \mathrm{S} .\end{array}$ & $\begin{array}{r}11 \\
2\end{array}$ & $\begin{array}{l}3 \\
1\end{array}$ & $\begin{array}{l}1 \\
5\end{array}$ & $\begin{array}{l}1 \\
9\end{array}$ & $\begin{array}{r}1 \\
11\end{array}$ & - & - & - & $\begin{array}{r}3 \\
-\end{array}$ & $\begin{array}{l}1 \\
2\end{array}$ & $\begin{array}{r}3 \\
10\end{array}$ & $\begin{array}{l}6 \\
4\end{array}$ & $\begin{array}{r}16 \\
9\end{array}$ & $\frac{21}{17}$ & $\begin{array}{l}20 \\
14\end{array}$ & $\begin{array}{r}13 \\
6\end{array}$ & $\begin{array}{r}39 \\
67\end{array}$ & $\begin{array}{l}208 \\
368\end{array}$ \\
\hline April & $\begin{array}{l}0^{\circ}-5^{\circ} \mathrm{S} \\
5^{\circ}-10^{\circ} \mathrm{S}\end{array}$ & $\begin{array}{l}2 \\
4\end{array}$ & - & - & $\begin{array}{l}3 \\
8\end{array}$ & - & $\begin{array}{l}2 \\
5\end{array}$ & $\begin{array}{l}2 \\
1\end{array}$ & - & $\begin{array}{l}2 \\
3\end{array}$ & $\begin{array}{l}2 \\
1\end{array}$ & $\begin{array}{r}13 \\
7\end{array}$ & $\begin{array}{r}18 \\
5\end{array}$ & $\begin{array}{r}12 \\
3\end{array}$ & $\frac{22}{17}$ & $\begin{array}{r}7 \\
10\end{array}$ & $\begin{array}{r}15 \\
4\end{array}$ & $\begin{array}{r}73 \\
51\end{array}$ & $\begin{array}{l}251 \\
482\end{array}$ \\
\hline May & $\begin{array}{l}0^{\circ}-5^{\circ} \mathrm{S} \\
5^{\circ}-10^{\circ} \mathrm{S}\end{array}$ & - & - & $\begin{array}{l}1 \\
2\end{array}$ & $\begin{array}{l}4 \\
6\end{array}$ & $\begin{array}{l}15 \\
18\end{array}$ & $\begin{array}{l}11 \\
15\end{array}$ & $\begin{array}{l}17 \\
20\end{array}$ & $\begin{array}{l}2 \\
4\end{array}$ & $\frac{25}{4}$ & $\begin{array}{l}9 \\
3\end{array}$ & $\begin{array}{l}4 \\
4\end{array}$ & $\begin{array}{l}2 \\
5\end{array}$ & $\begin{array}{l}6 \\
1\end{array}$ & $\begin{array}{l}2 \\
2\end{array}$ & $\begin{array}{r}1 \\
15\end{array}$ & $\begin{array}{l}1 \\
1\end{array}$ & $\begin{array}{l}70 \\
67\end{array}$ & $\begin{array}{l}414 \\
483\end{array}$ \\
\hline June & $\begin{array}{l}0^{\circ}-5^{\circ} \mathrm{S} . \\
5^{\circ}-10^{\circ} \mathrm{S} .\end{array}$ & - & - & - & $\begin{array}{l}5 \\
8\end{array}$ & $\begin{array}{r}3 \\
25 \\
\end{array}$ & $\begin{array}{r}10 \\
13\end{array}$ & $\frac{37}{16}$ & $\begin{array}{r}11 \\
2\end{array}$ & $\begin{array}{l}5 \\
3\end{array}$ & $\begin{array}{r}10 \\
2\end{array}$ & $\begin{array}{l}6 \\
6\end{array}$ & $\begin{array}{l}1 \\
2\end{array}$ & $\begin{array}{l}7 \\
4\end{array}$ & $\begin{array}{l}3 \\
4\end{array}$ & $\begin{array}{l}2 \\
3\end{array}$ & $\begin{array}{l}0 \\
2\end{array}$ & $\begin{array}{l}61 \\
59\end{array}$ & $\begin{array}{l}290 \\
718\end{array}$ \\
\hline July & $\begin{array}{l}0^{\circ}-5^{\circ} \mathrm{S} . \\
5^{\circ}-10^{\circ} \mathrm{S} .\end{array}$ & - & $\begin{array}{l}1 \\
1\end{array}$ & - & $\begin{array}{l}2 \\
8\end{array}$ & $\frac{26}{19}$ & $\begin{array}{l}19 \\
25 \\
\end{array}$ & $\frac{27}{12}$ & $\begin{array}{r}11 \\
3\end{array}$ & $\begin{array}{l}8 \\
4\end{array}$ & $\begin{array}{l}2 \\
5\end{array}$ & $\begin{array}{l}2 \\
1\end{array}$ & $\begin{array}{l}1 \\
2\end{array}$ & - & - & - & - & $\begin{array}{l}43 \\
56\end{array}$ & $\begin{array}{l}453 \\
751\end{array}$ \\
\hline August & $\begin{array}{l}0^{\circ}-5^{\circ} \mathrm{S} \\
5^{\circ}-10^{\circ} \mathrm{S}\end{array}$ & - & - & $\begin{array}{l}2 \\
3\end{array}$ & $\begin{array}{l}4 \\
2\end{array}$ & $\begin{array}{l}20 \\
16\end{array}$ & $\frac{22}{30}$ & $\frac{29}{21}$ & $\begin{array}{l}8 \\
7\end{array}$ & $\begin{array}{l}4 \\
5\end{array}$ & $\begin{array}{l}8 \\
4\end{array}$ & - & $\begin{array}{r}1 \\
-\end{array}$ & $\begin{array}{r}1 \\
-\end{array}$ & 1 & - & - & $\begin{array}{l}46 \\
47\end{array}$ & $48(t)$ \\
\hline Sept. & $\begin{array}{l}0^{\circ}-5^{\circ} \mathrm{S} . \\
5^{\circ}-10^{\circ} \mathrm{S} .\end{array}$ & - & - & - & $\begin{array}{l}2 \\
3\end{array}$ & $\begin{array}{l}16 \\
34 \\
\end{array}$ & $\frac{23}{26}$ & $\frac{24}{17}$ & $\begin{array}{l}6 \\
3\end{array}$ & $\begin{array}{r}14 \\
6\end{array}$ & $\begin{array}{l}5 \\
2\end{array}$ & $\begin{array}{l}8 \\
4\end{array}$ & - & $\begin{array}{l}2 \\
1\end{array}$ & - & - & - & $\begin{array}{l}45 \\
48\end{array}$ & 416 \\
\hline Oct. & $\begin{array}{l}0^{\circ}-5^{\circ} \mathrm{S} \\
5^{\circ}-10^{\circ} \mathrm{S}\end{array}$ & $\begin{array}{r}2 \\
-\end{array}$ & - & - & $\begin{array}{l}6 \\
3\end{array}$ & $\begin{array}{l}18 \\
14\end{array}$ & $\begin{array}{l}11 \\
30 \\
\end{array}$ & $\frac{31}{35}$ & $\begin{array}{l}6 \\
2\end{array}$ & $\begin{array}{r}10 \\
7\end{array}$ & $\begin{array}{l}9 \\
7\end{array}$ & $\begin{array}{l}4 \\
2\end{array}$ & - & $\begin{array}{r}2 \\
-\end{array}$ & - & $\begin{array}{r}1 \\
-\end{array}$ & - & $\begin{array}{r}64 \\
35\end{array}$ & $\begin{array}{l}276 \\
224\end{array}$ \\
\hline Nov. & $\begin{array}{l}0^{\circ}-5^{\circ} \mathrm{S} . \\
5^{\circ}-10^{\circ} \mathrm{S} .\end{array}$ & 2 & 2 & 2 & 4 & 22 & 23 & 6 & 15 & 1 & 6 & 4 & - & 3 & 3 & 3 & 4 & 37 & 108 \\
\hline Dec. & $\begin{array}{l}0^{\circ}-5^{\circ} \mathrm{S} \\
5^{\circ}-10^{\circ} \mathrm{S}\end{array}$ & $\ldots$ & - & - & - & 21 & 32 & - & 5 & - & - & - & 5 & 11 & - & 26 & - & 48 & 54 \\
\hline
\end{tabular}

[The numbers in thinner type in the above table denote that more than $10(17 \%)$, the underlined numbers denote that more than $\frac{1}{3}(33 \%)$ of all the winds come from one direction.]

(From the Segelhandbuch für den indischen Ozean, p. 556.) 



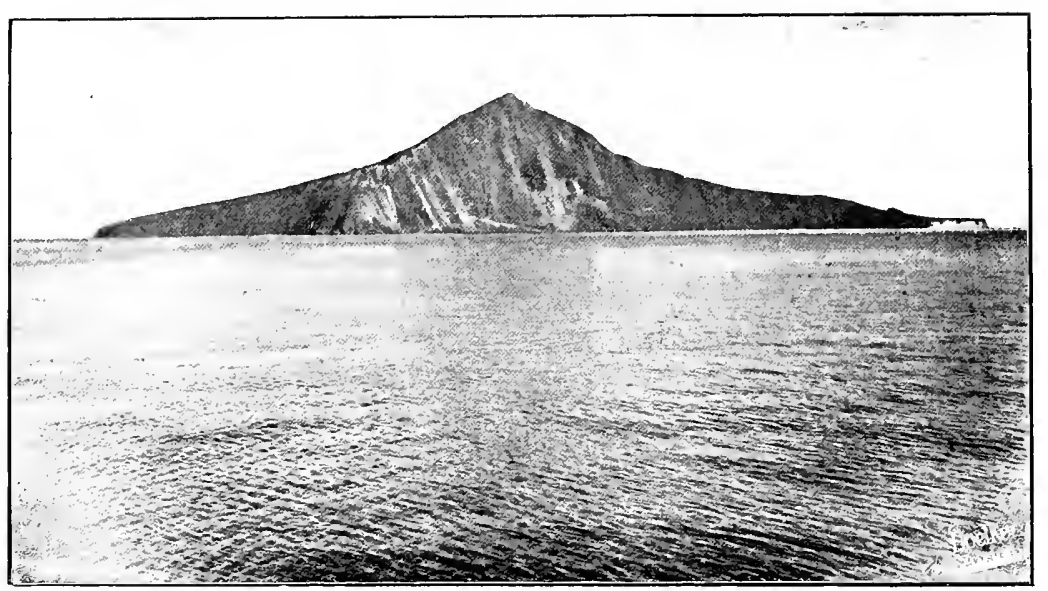

Photo. A. Eirust.

Fis. 1. View of Krakatau from the North (1. 26).

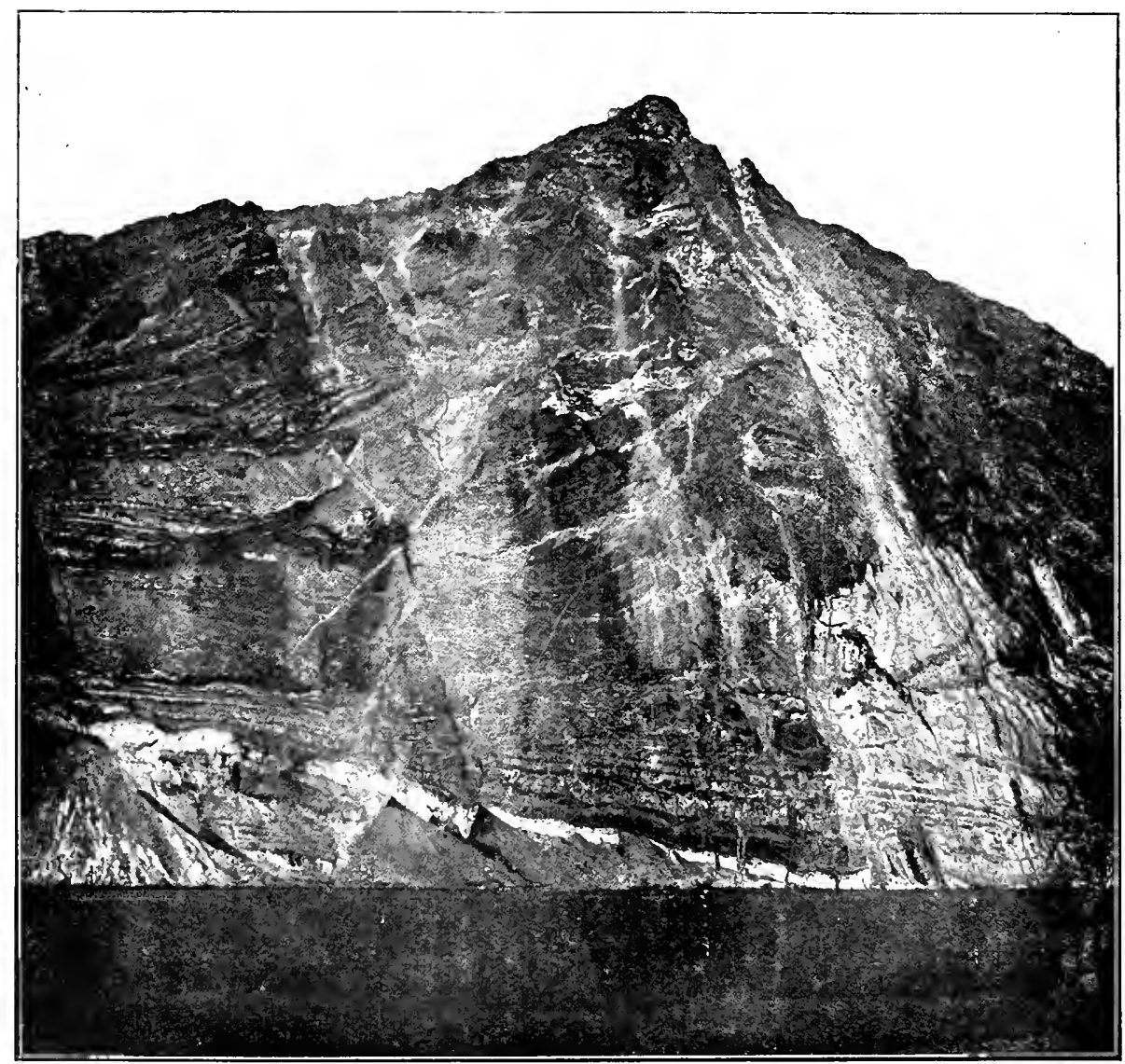

Photo. A. Errost.

Fia. 2. Peak of Rakata ( $832 \mathrm{~m}$.) and the fractured rock-face (1. 33). 
calm. On the other hand, during the months of the west monsoon, from December to February, the tides set strongly for about 18 hours towards the north-east and flow only for 6 hours with a feeble current towards the south-west.

In the daytime the prevailing flow is interrupted by currents in the opposite direction or by calns; at night the flow is continuous, reaching its maximum force at the time of new and full moon and its minimum at the quarter moon. During the intermediate period, November, March, and April, and at other times when the wind conditions are less strongly marked, the differences in duration and force of the two flows tend to disappear.

The general direction of the currents is north-east and south-west, but local variations occur depending on the form of the coast-line. The direction is north-north-east and south-south-east at the northern entrance to the strait on the coast of Sumatra between North island and Strom Rock (Stroomklip), also on the coast of Java between Third and Fourth Point (derde punt and vierde punt); between Krakatan and Prince island (Prinsen Eiland) east-north-east and west-south-west, between Seboekoe and Hogspitze (Varkens Hoek) east-south-east and west-north-west. On the whole the current flows in the Sunda Strait throughout the year much more in a southwesterly than in a north-easterly direction. During the east monsoon the deflexion of the south-west current towards the north-east current is not infrequently so strong that, as the result also of the prevailing light winds of this season, sailing ships going north are delayed for days or are driven back into the strait (Segelhoudbuch, p. 567).

The current sets strongest in the northern entrance to the strait, where its velocity frequently exceeds 5 kilometres per hour; in the broad chamnel between Krakatan and Prince island a velocity of $3-4 \mathrm{~km}$. is not uncommon, but on an average it is only $1.5-2 \mathrm{~km}$. ; in the Prince Channel and on the Javan coast from the Second to the Fourth Point the current is considerably weaker, at least that which flows in a south-westerly direction.

\section{On the south-west coast of Java: "Java's First Point."}

About three hours after leaving Vlakke Hoek we were in the middle of the Sunda Strait; the peak of Krakatau was visible towards the east, rising above heavy clouds. Our next destination lay still further sonth. At 3 o'clock we sighted the coast of Java and in front of it Prince island. We were soon in calm water behind Prince island and reached the calm bay which is enclosed by the coast of Java and the small Gull island "Neeuwen Eiland." We had 
a glorious view of the wooded high ground and of the cone of Goenong Pajoeng, 470 metres high.

On a rocky headland 40 metres high the masonry of the lighthonse, visible even in the daytime for a considerable distance, rises in front of us against a background of the dark green edge of the forest. Rather more to the left a solitary storehouse stands on the beach and next to it are the ruins of a large fort with its foundations projecting far into the water. It was to this wall that our boat brought us through the surf about 4 p.m. We were allowed to remain on shore collecting until sunset. The captain had taken the precantion to provide us with arms and ammmition from the ship's armoury, as tigers and rhinoceroses are still plentiful in the outlying parts of West Java. We endeavoured to ensure a safe passage through the dark strand-forest and the adjacent grass thickets by repeatedly firing our guns.

Ipomace Pes-caprae sprawls over the ground at the landing-place; there are large bushes of Hibiscus tilincens, Scacvola Koenigii, and Tournefortia argentea in flower. 1schaemum muticum and Euphorlhia Atoto, with Wedelia glabreta, Ageratum conysoides and other Composites grow beneath tall plants of Calopleyllum draped with the thickleaved Hoyg. Stout rhizomes of Polypodium quercifolium bearing two forms of leaf, bracket-leaves with the habit of large oak leaves alternating with simply pinnate fertile fronds, creep over stems and branches. The older parts of the rhizomes bear numerous and crowded brown skeletons of the humus-collecting bracket-leaves, while the younger portions bear only ordinary fronds. Spiny Rotangs and low Pandanus plants render penetration into the interior difficult, where Succharm spontuneum, varions Cyperaceae, and ferns cover the ground; tree stems and large blocks of coral rock, which had been swept by the flood of 1883 to a distance of several hundred metres on to the land, are decked with creeping and climbing plants. Nephrolcpis cxaltate occurs both as an epiphyte and growing in the ground; the plants of the undergrowth are overgrown by Lygodium dichotomum with its deeply palmate leaf segments. Aerides odlorata and a Zingiberaceons species, Costus speciosus, are conspicuous by the brightness of their flowers. The 36 vascular plants (32 phanerogams and 4 ferns) which we took back with us to the ship are enmmerated in the following list:

Fam. Compositae: Ageratum conyzoides L.

* Blumea balsamifera D.C.

Vernonia cinerea Less.

* Velelia glabrata B. et $\mathrm{H}$. 
Fam. Goodeniucene: TScaevola Koenigii Vahl.

Fam. Rubiacene: Sarcocephalus cordatus (Roxb.) Miq.

Fam. Verbenucece: Gmelina villosa Roxb.

†Vitex pubescens Vahl.

*Vitex Negundo L.

Fam. Borraginaceas: †'Tournefortia argentea L.

Fam. Convolvulacene: +Ipomaea Pes-caprac Sw.

Fam. Asclepiadacene: *Hoya spec.

Fam. Apocynacene: †Cerbera Odollam Gaertn.

Fan. Lythracece: Lagerstroemia speciosa Pers.

Fam. Guttiferae: †Calophyllum Inophyllum L.

Fan. Dilleniacene: *'Tetracela Assa D.C.

Fam. Malvacene: tHibiscus tiliaceus L.

Fall. Vitucecte:

Leea sambucina Willd.

* Vitis arachnoidea Backel

Fam. Euphorbicuceue: †Euphorbia Atoto Forst.

Fan. Legminosac: †Desmodium umbellatum D.C.

†Sopliora tomentosa L.

Fam. Orchidecene: Aerides odor"atum Lour.

Fam. Zingiberecece: Costus speciosus Simith

Fam. Amaryllidaceae: †Crinum asiaticum L.

Fam. Lilicucue: Smilax spec.

Fam. Cyperaceae: †yperus brevifolius Valck. Sur.

†Cyperus cyperinus Valck. Sur.

Cyperus umbellatus Benth. (Mariscus umbellatus Vahl.)

Fam. Gromineae: fIschaemum muticum $\mathbf{l}$.

Saccharum spontanemu L.

Fann. Pandenceceae: * Pandanus spec.

Fam. Schisececere: Lygodium dichotomm Swartz

Fam. Polypodicacene: Nephrolepis exaltata Schott

* Polypodium quercifolium L.

Pteris longifolia L.

The flora in the neighbourhood of Java's First Point is essentially different in composition from that of Tandjong Rata (Sumatra) and Edam. The 36 species belong to no less than 24 different families. The marked decrease in the number of typical strand-plants is a particularly striking feature.

While in the Edam flora the halophytes constitute $46 \%$, or, including the species indicated by $* 72 \%$ of the total, and in Vlakke Hoek they constitute $57 \%$, or, with the additional species, $83 \%$ of the total number, only $14(39 \%)$ of the 36 plants obtained from Ja va's First 
Point, or, with additional species (* in the list), 21 (that is $58 \%$ ) belong to the Indo-Malayan strand vegetation. The 15 remaining species belong to plants characterised by a wide distribution-area. The Composites Ageretum conyzoides and Vernonia cinerea inhabit the warmer regions of the world; Sarcocephulus eordatus, Lagerstrocmia speciosa, Tetracera Assa, and Leea sambucina extend from Further India to South China, from the Malay Archipelago to the Philippines and to Australia; similarly Acrides odoratum, Saccharum sponteneum and Cyperus umbellatus are widely spread over Java and Sumatra and far beyond them. It is, therefore, not surprising that we afterwards found in Krakatan as many as six of these 15 inland plants, the wide range of which is clearly connected with the adaptation of their seeds and firuits to dispersal.

As we returned to the steamer at six o'clock the sun was setting behind the lighthonse, the red sky glowing with brilliant colour, above the calm waters of the bay encireled by the sombre forest. The nocturnal life of the forest was awake; bats of all sizes fluttered through the air, flying foxes (Kalong) passed noiselessly with slow flight over the bay in search of firuit. The screams of monkeys resounded in the forest, the wild boars were astir in the Alang-Alang thickets, while tigers, panthers, and wild cats slunk out of their hidingplaces in search of prey.

The "Snip" remained at anchor till midnight off' Java's First Point. We spent the first part of the welcome leisure in arranging and pressing our collection of plants and afterwards enjoyed a wellearned rest in the deck-chairs. As the ship left the sheltered bay and steamed into the open Sunda Strait between Prince island and Java our rest was interrupted; the rolling began afresh and the waves breaking over the deck compelled the slecpers to beat a hurried retreat to the narrow and close cabin.

\section{On Kraliatan and Verlaten island.}

At dawn on April 26th our steamer was slowly approaching the Krakatan group. Krakatau, the object of our voyage, with its characteristic volcanic shape, stood out a short distance ahead. The precipitous face reaching from sea-level to the summit of the fiactured cone is a conspicuous object (Pl. III.). Towards the south-east the halfconical mountain slopes steeply to a flat base, in front of which is a small and level beach. Lang island lies to the right of Krakatan and Verlaten island is visible between them. Further to the right, in a north-easterly direction, we can see the high wooded islands of Sebesi and Seboekoe and the mountains of Sumatra, and to the southeast the Javan coast. 



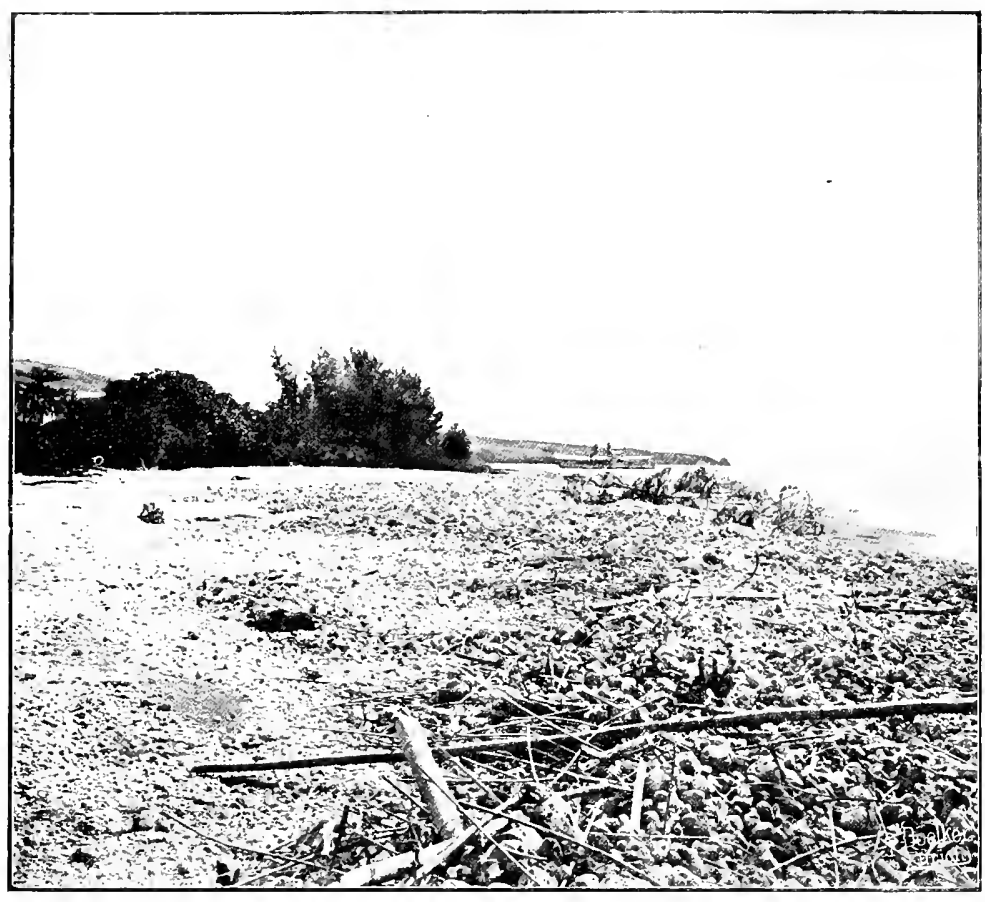

Fig. 3. Drift-zone on the sonth-east coast of Krakatau. Strand-forest in the background (p. 27).

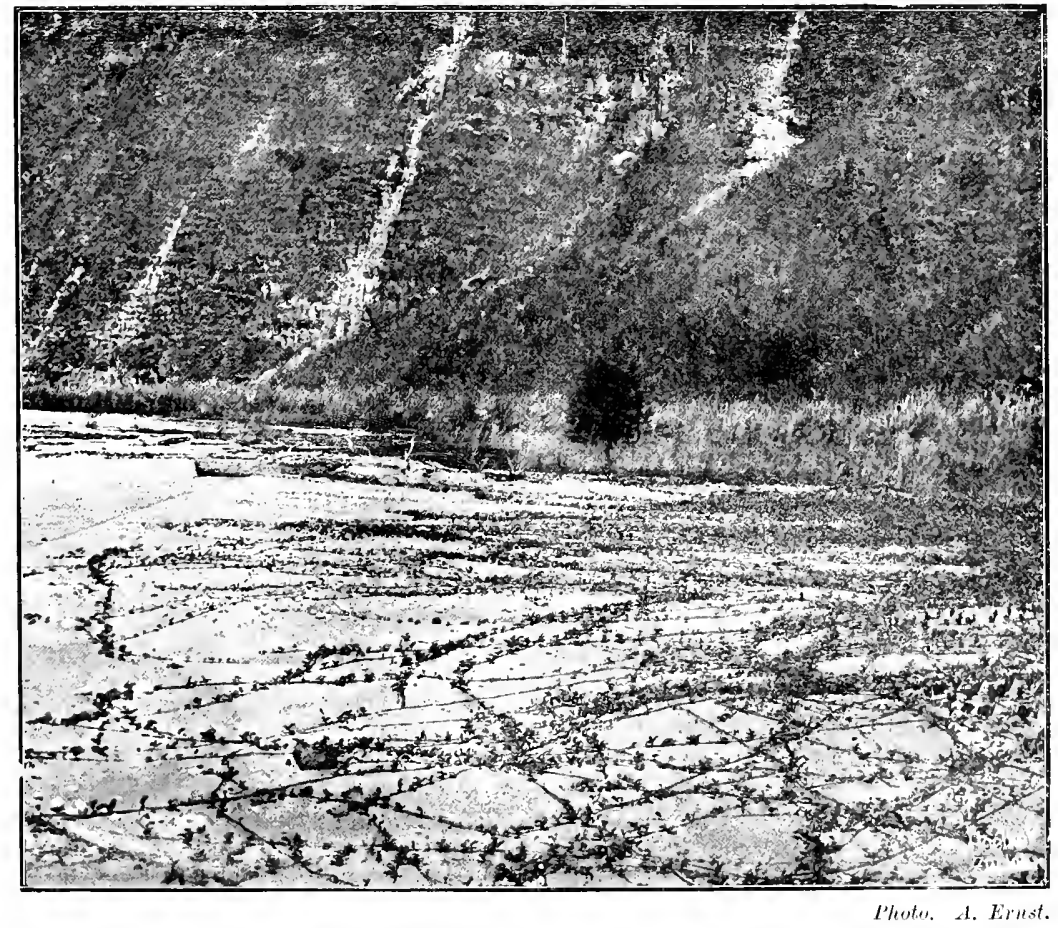

EIG. 4. Level beach between the fractured rock-face and the promontory of Zwarte Hoek.

In the foreground the long creeping shoots of Ipomaed Pes-cuprae and Vigna lutea (p. 34). 
As we approached the east coast of Krakatan we noticed with growing amazement the remarkable progress made by the vegetation. Almost the whole south side, from the beach to the summit and to the edge of the steep promontory, is covered with green. On the south-east coast, where we first thought of landing, a belt of forest rmus parallel to the shore in which we conld recognise from a distance numerous grey-green Casuarina trees. Further to the south rose the dark green leaves of coconnt palms in association with slender broadleaved trees bearing whorls of branches. Isolated trees and shrubs were seen on the low-lying ground which rises gradually to the base of the conical mountain; in some of the ravines half-way up the hill they form patches of forest, reappearing as scattered plants on the ligher ridges and on the peak.

At six o'clock the anchor was let go and after waiting impatiently we took the boat orer the punice-strewn water to the level beach. Here at the upper limit of the tide-swept zone (Pl. IV., fig. 3) we examined the material which the waves are constantly throwing up on to the desolate shore. Amongst the débris of tree stems and broken branches, with which the beach is covered, blocks of coral of all sizes are seattered over the loose surface of pumice, in which one sinks ankle-deep at each step, mixed with brown sea-weeds, broken univalve and bivalve shells and green balls of algae. Fruits and seeds of land-plants are mixed in abundent variety with the flotsann of the waves: the cases of many of them, decayed beyond recognition or completely rubbed off, aflord striking evidence of a long and stormy voyage. Some, on the other hand, are absolutely fresh, as if recently fallen from the tree.

Several of the fruits have germinated and are anchored by long tap-roots to the ground; others have been bored or completely hollowed out by animals, particularly those of the coconut, the largest of the drift-fruits. The ovate fruits of Cerbere Odollem, $10 \mathrm{~cm}$. [3.9 inches] in length, are met with in abundance; the outer coat has usually been removed, laying bare the loose floating tissue consisting of a felted mass of slender fibres. The brownish-black ribbed fruits of a strand-palm, Nipe fiuticens, frequently occur; also the irregularly angular seeds from the golden yellow fruits of Corropec which reach the size of a man's head, single fruits and pieces of the inflorescence of Pandanus, the large four-sided fruits of Barringtonia speciose, the flat boat-shaped kernels of Terminalice Catappa, spherical fruits of Calophyllhm, the drupe-like seeds of Cycas, and many other large and small fruits and seeds. On the previous day we had eolleeted almost the same set of fruits and seeds on the shores of the coral islands Edim and Pajoeng in the Java 
Sea or from the different localities which we visited on the coasts of Java and Sumatra. They all belong to strand-plants which are not confined to the coasts of Java and Sumatra and the numerous islands in the Java Sea or to the Malay Archipelago, but are widely distributed from Africa to New Guinea, some species being met with throughout the whole of the tropics. It is these plants which constitute the first colonists of recently formed coral reefs and islands. They owe their lightness and buoyancy to air-spaces in the pericarp and testa or to the abundance of light floating tissue, while a hard and impervious imer coat affords protection to the embryo against the injurious effects of sea-water. It is by virtue of these features that the seeds and fruits of strand-plants are widely distributed and act as the pioneers of vegetation on land recently raised above sea-level.

The species which we found in the new strand-flora of Krakatan are typical strand-plants. Within the Drift-zone we came to a low carpet of a tropical dune-flora, the Pes-capmate formation, as it has been called by Schimper, forming a zone in front of the forest-belt which varies in breadth according to the nature of the ground. We had previonsly met with the most striking and important representatives of this formation on the sandy littoral of Edam. Here, as in Edam, the rumers of Spinifex squerrosus and the long trailing shoots of Ipomaca Pes-caprae ${ }^{1}$ rooted at the nodes and bearing large fumnelshaped flowers of a blue-violet colour and thick fleshy leaves form a network on the loose substratum. With these are associated shoots of some Legmininons species clinging close to the ground, the yellowflowering Vigna lutea and Vigma luteola and the large-leaved Canucalia obtusifolia. Here and there tall grasses and Cyperaceae rise above the regular network of creeping stems, a spurge, characterised by waxy glaucous leaves and low bushes becoming taller and more abundant as we approached the forest-belt. We found several old acquaintances from Edam and Vlakke Itoek, the widely spread Malvaceous species, Hibiscus tiliacens, with its beautiful yellow flowers, also Scacvola Kocnigii, Clerodendron incrme, and Premnce foctida; a thick felt of the yellowish-green cylindrical threads of Cassytha filiformis, assuming a brown-red colour in sumny places, covered the grasses, herbaceous plants and bushes as well as the branches of the taller shrubs and trees of the neighbouring strandforest (Plate V., fig. 6 ; Pl. VI., fig. 7).

The young strand-forest of Krakatau which stretches beyond the low zone of the Pes-caprae formation, and is still characterised by

[1 Compare an aeeount of the Flora of the Ceylon littoral by A. G. Tansley and F. E. Fritsch published in the New Phytologist, Vol. Iv. p. 1, 1905.] 


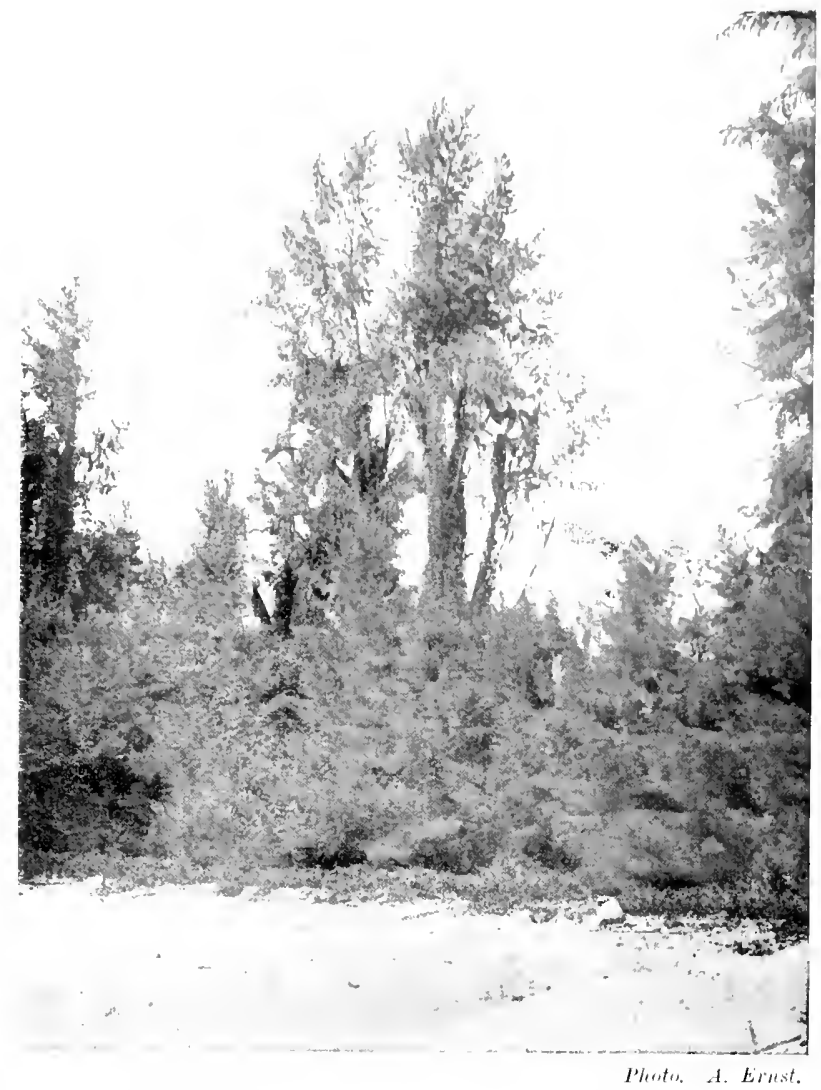

Fig. 5. Casuarina cquisetifolia in the strand-forest of Krakatan.

In front of the oldest Casuarinas, festooned with ritis trifolia and other climbing plants, is a belt of younger plants of Casuarina (p. 29).

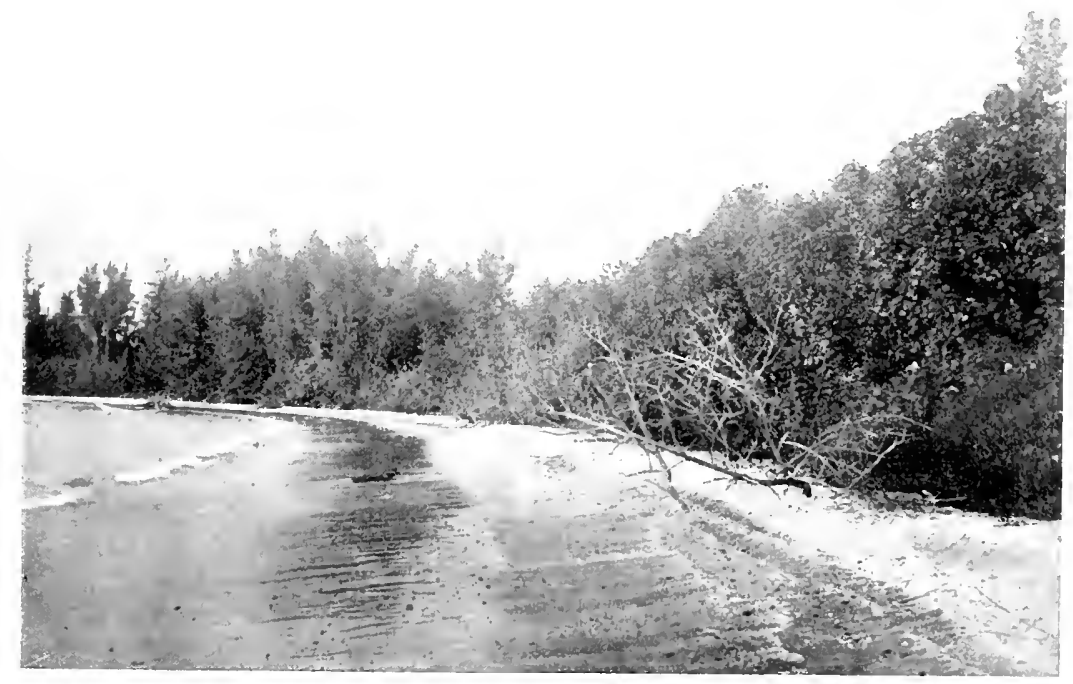

Phote. A. Errest.

Fig. 6. The New Strand-forest on the south-east coast of Krakatan.

To the right occur Hibiscus tiliaceus, Pandanus sp., Cycas circinalis; to the left a closed formation of Casuarina equisetifolic; in the foreground a tree washed up by the sea $(p, 28)$. 

numerons elearings, is chietly eomposed of such trees and shrubs as the botanist recogmises in his first excursion into a Javan strand-forest and as we had met with on Edam, at Vlakke Hoek and Java's First Point. Tall Casnarinas, 12-15 metres [39-49 feet] high, form the largest portion of the closed forest-formation (Pl. V., fig. 5). Young individuals of the same trees linked to the neighbouring shrubs by slender climbing plants, such as Cassytha, Vigma, Comorollia, Corescelpinio Bomlueflla, Vitis trifolia, constitute an almost continuons mass of foliage; the shoots of ritis trifolic are especially abmudant, winding over the tallest Casuarinas and covering their stems and branches with a luxuriant mosaic of leaves.

At the elge of the group of Casuarinas we discovered a fine specimen of a female plant of Cyeces circinalis, bearing a handsome erown of fronds at the apex of a trunk 1 metre $65 \mathrm{~cm}$. [5 feet 9 inches] high and $80 \mathrm{~cm}$. in circumference; the growing-point was surrounded by yellowish-brown carpellary leaves the ovules of which showed signs of shrinkage. Like those of previous year's which lay on the ground, they were evidently destined to remain unfertiliserl. It is improbable that ripe Cycas seers will be found in Krakatan in the near future, as in spite of diligent seareh we saw no male plants either on Krakatan or on Verlaten island, nor did we discover any other female plants's. Further to the south, slender stems of Calophyllum Inophyllum and Terminalia Crotrape with their whorled branches struggle upwards above the zone of trees and shrubs (Frontispiece). The leaves of both these trees are leathery, while in other species which we found here, such as Sophora tomentosa, Clevodendion inerme, Pomplites acidula, Moriude citrifolia, they are fleshy, or like those of Tomrusfortice argenter, especially on the younger branches of the plant, they are clotherl with a dense felt of hairs. These plants like other trees and shrubs of the new forest-zone belonging to the Leguminosae, Enphorbiaceae, Rubiaceae, Jythraceae and other families, with the grasses, Lanraceae, Leguminosac and Compositae, which grow in the clearings, are all well adapted by their vegetative structure, particularly in the form and anatomical structure of their leaves, to an existence in gromnd rich in salt and which therefore, from a botanical point of view, despite the abundance of water, constitutes a physiologically dry habitat. Above a clearing overgrown with tall grass we could see some specimens of the most beautiful tree of the tropical strand-forest, the Myrtaceous plant Brrringtonic speeiosa, after which the whole type of regetation of these forests has been named the Barringtonia formation. The large white flowers present a striking appearance against the background of a dense canopy of

\footnotetext{
1 See Addendum I., p. 72.
} 
gigantic lanceolate leaves. The lowest branches bear the mitre-like and light fruits in all stages of development in association with the flowers.

Still further south coconut palms, the leaves of which we had seen through our glasses from the ship, tower above the groups of trees (Pl. VIII., fig. 11). It was with some diffieulty that we made our way to them over large bloeks of pumice, through a tangle of reeds and grasses and thick bush. Half-way we came to a group of large-leaved fig-trees, Ficus fulva and Ficus fistulosa, in full fruit, and, like many other tropical trees, bearing flower and fr'nit on the stem and older branches instead of on the younger shoots. The slender stems of Trichosanthes tricuspiclata, a Cucurbitaceous climbing plant, sprawl over the twigs and branches of the fig-trees, its light-red fruits standing out against the dark green foliage. The fig-trees, now represented by six species in Krakatau and Verlaten island, and Trichosemthes belong to those colonists the seeds of which are said to have been brought to the island by fruiteating birds (endozoic).

To our great delight we found the coconut palms laden with firuit. The large number of ripe nuts on the ground, several of which had germinated and produced plants reaching one metre in height, showed that they must have attained the finiting stage some years ago: a renewal of the forest is thus amply provided for. We were all refreshed by a quantity of mipe fruits which one of our Javanese companions bronght down from the crowns of the palm-trees.

The region north-east of the Casuarina forest seemed to us to afford the most appropriate ronte by which to penetrate into the interior of the island and to the slopes of the cone. The strandforest is here reduced to a very narrow zone and the girdle of ereeping vegetation is at several points interrupted by the extension of the bush to the tide-level. Among taller plants which overlap the others are some coconnt palms and handsome Pandanus clumps, reaching a height of $6-8$ metres (Pl. VI., fig. 8 and fig. 9, Pl. VII.), with their slender stems bent like snakes and anchored to the wave-swept beach by thick columnar roots ; the yellow and red masses of fruit as large as a man's head make a brilliant show in the dense crowns of narrow sharp-edged leares. Close by we found a young coconut palm not yet at the fruiting age, a plant of the dwarf variety, termed by the natives "Kalapa gading," the fruits of which when fully ripe are of a beantiful orange-yellow colour.

Following inland one of the broad stream-beds which the rapidly flowing water after the heavy rains had carved out of the soft strata, we soon found ourselves in the midst of a regetation entirely different from that of the strand-flora. At the edge of the bed of the stream 


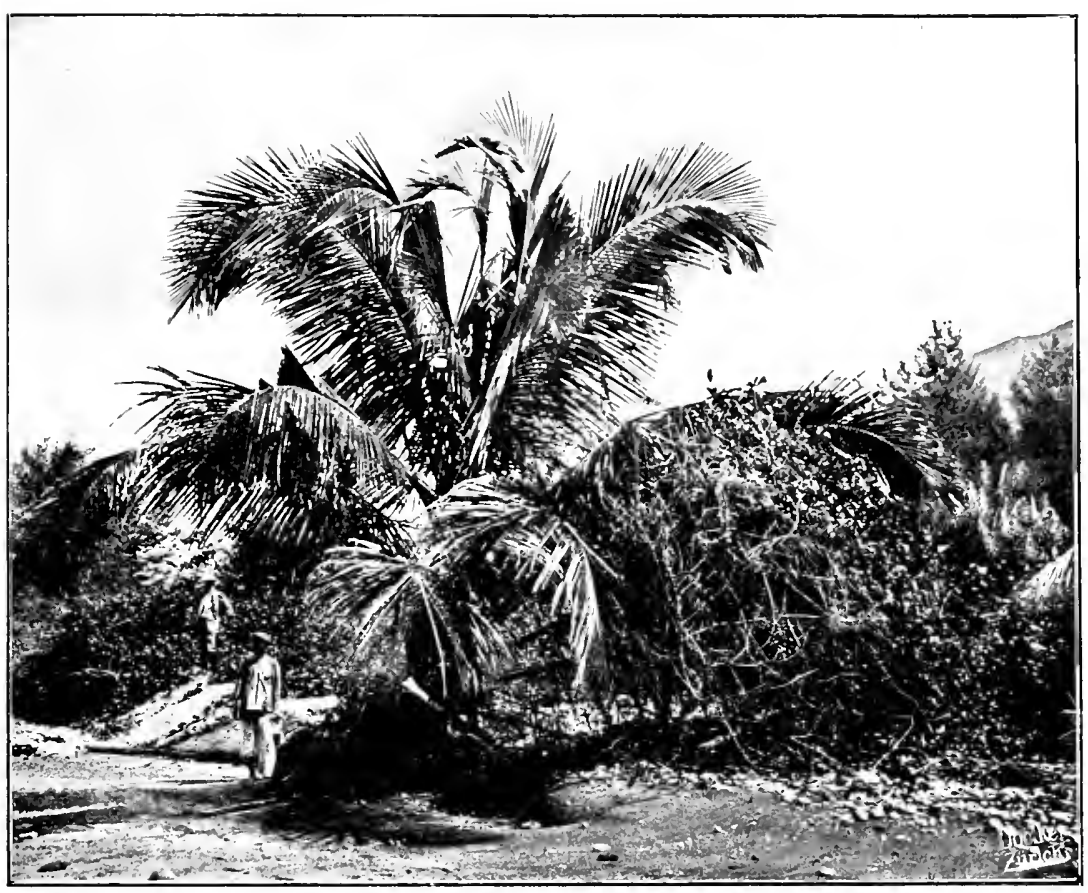

Plhoto. A. Eirnst.

Fig. 7. Young coconnt palm at the upper edge of the tide-level (south-east coast of Krakatau).

To the left Ipomaea Pes-caprae; to the right a shrub with Cassytha filifirmis (p. 28).

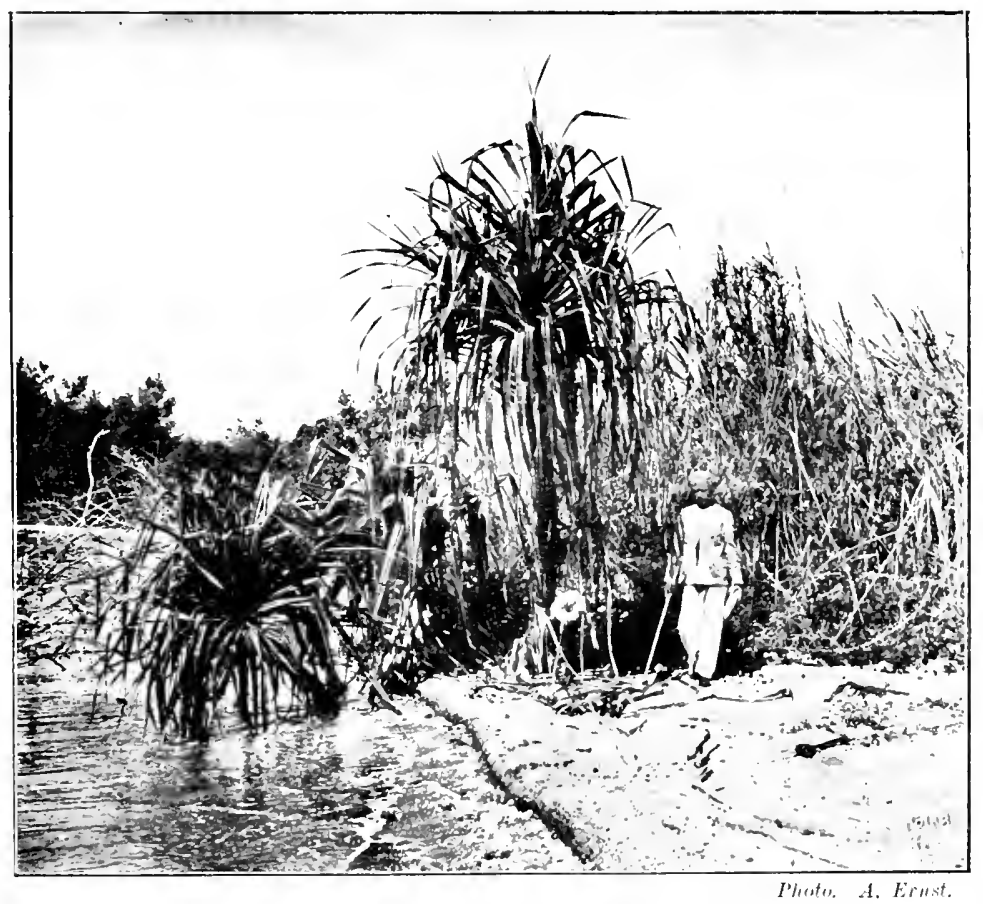

FIa. 8. Pandanus on the beach (east eoast of Krakatau).

To the right Saccharum spontaneum; in the background, to the left, Casuarina forest (p. 30). 
we found clumps of small mosses (Philonotis secunde [Dz. and Mb.] v. d. B. and Lae. and Bryum coronotum Schwaegr.) and delieate ferns, espeeially G!ymogramme calomelanos with its young fronds covered with white ealcareons scales. Blocks of pumice and lava lying in hollows below undermined banks were eovered with a mantle of blue-green algae. By the sides of the stream, on undulating gromud sloping upwards towards the momntain, some of the shore species of grasses and Cyperaceae predominated, and of the plants associated with them Saccharum spontaneum, Gymmothrix elegans, and Phraymites Roxburghii are remarkable for their unusual size. Their stems, 3-4 metres ligh, form at first seattered bushes, in other places in company with Vigne, Canaralia and Cassytha, which occur here as climbing plants, they form regular thickets associated with shrnbs of Toumefortia, Scaevola, and varions ferns.

A sudden rustling in the reeds in front of us was eansed by a yellowbrown lizard (probably the strong swimming species, Varames salirator Laur.), nearly 1 metre long, which had been lazily basking in the sun and made off in great haste. The fact that Selenka ${ }^{1}$ and sluiter found two speeimens of Calotes juluatus in 1894 renders it probable that other lizards, in addition to Vrerames, occur on the island. Birds have also already established themselves on Krakatan. We oceasionally saw gulls above the strand-forest, and in the interior of the island small birds flew noiselessly from the bushes to seek a (puieter resting-place a short distance away. Beyoud the strandforest the whole gently sloping surfice of the sonth-east side of the island was covered with the steppe-like regetation which we have deseribed and this extended in a dense mass into the wild ravines and on to the steep sides far up on the eone. The uniformity of the jungle of fresh and decaying stems of grasses and reeds is only oceasionally broken by the ocenrence of a fallen tree or shrub.

Stretehing in front of us half-way up the slopes of Rakata was a deep ravine the dark vegetation of which, rich in trees and shrubs, we had noticed as the ship approached the island. We attempterl to penetrate the thicket and succeeded in reaching the first steep ridges which, with the intervening deep furrows and ravines, radiate in all directions on the slopes over the foot of the mountain (Pl. VIII., fig. 12) ${ }^{2}$. We elambered up to the ridge throngh a tangle of grasses waving above us, then down the ravines; it was tiring work, the

1 Sclenka, E. and L. Somnige Welten. Ostasiatische Reiseskizzen. Edit. II. Wiesbaden, 1905, p. 138; also a communication by letter from Prof. Sluiter of Amsterdam.

$\left[{ }^{2}\right.$ This photograph (Pl. VII ., fig. 12) was originally reproduced in Penzig's paper in the Annales du. Jurdin betunique de Buitenzorg, 1902, p. 104.] 
flora was monotonous and at first we found but few interesting plants. Ferns and grasses occurred everywhere ; rarely were our eyes gladdened by the stately infloreseence of some tall orchids of grass-like habit growing in the ground, Arundina speciosa, Spathoglottis plicata, Phajus or C!mbidium and yellow-flowering Composites. We were, however, sorely tried by the representatives of the new fauna of Krakatau. In the lower Casuarina forest swarms of gnats flew about us and in collecting Pandanus fruits we disturbed small and dangerous wasps. Here on the higher slopes we found ourselves in the domain of a host of red and black, large and small ants. Their nests were partly hidden in a layer, 1 metre thick, of decaying roots, broken and withered reeds and grasses, some of them hanging like nests on the shrubs and grass bushes. These small pests fall from their nests in showers on the intruders.

We were still separated from our goal by many ridges always increasing in steepness and by deep ravines. Scorched by the burning rays of a vertical sun, we took turns, at the head of our small party, in liandling the knife and cut our way step by step now up now down through the shadeless thicket. Our servants and carriers were barely able to keep up with us with the necessary luggage and the plant cases. At last we were reluctantly compelled to admit that with our primitive equipment and in the short time at our disposal it was impossible to reach the main gorge and the peak. In addition to the difficulties of the ascent due to the nature of the ground, we were confronted by a further difficulty presented by the thick growth of regetation which aftorded neither rest nor shade, so that our efforts, like those of the members of the earlier expeditions of 1886 and 1897 , were not crowned with success. It may perhaps be possible for members of a fourth expedition provided with a complete mountaineering and tropical outfit and with several days at their disposal to complete the investigation of the Krakatan flora; but meanwhile the ascent of the cone and the examination of its mexplored plant-world are still to be accomplished.

We retraced our steps; by midday we had reached the ship which steamed at a short distance from the land along the east and north coasts of the island. The appearance of the coast rapidly changed. The level shore passes into a steep beach terminated above by the fissured spurs of the mountain like those which we had just attempted to seale. The north side with its almost vertical face, 800 metres high, was an imposing sight. It showed the peculiar course of the varionsly coloured strata and veins, and afforded in an 


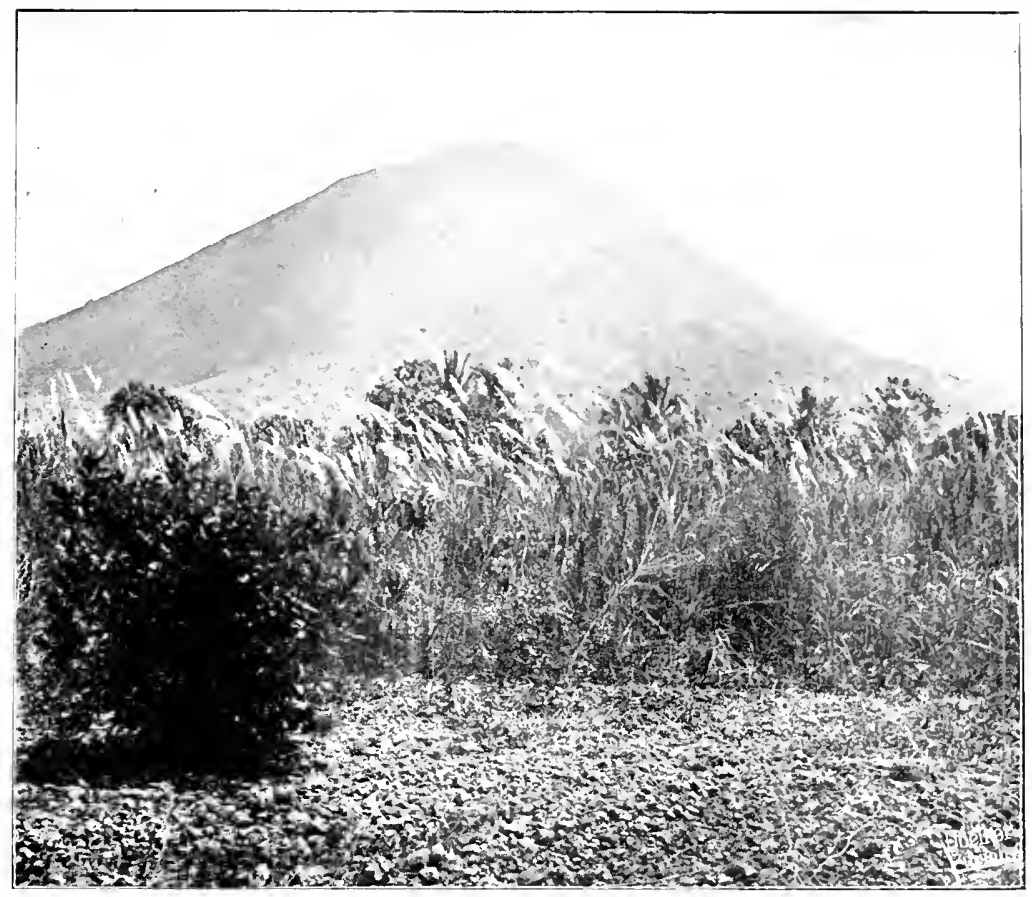

Litutr. A. Eirnst.

Fig. 11. Clearing in the Strand-forest.

To the left in the foreground Scaerola Koenigii; behind the grasses (Saceharum spontaneum) a group of coconut palms. South-east coast of Krakatau (p. 30).

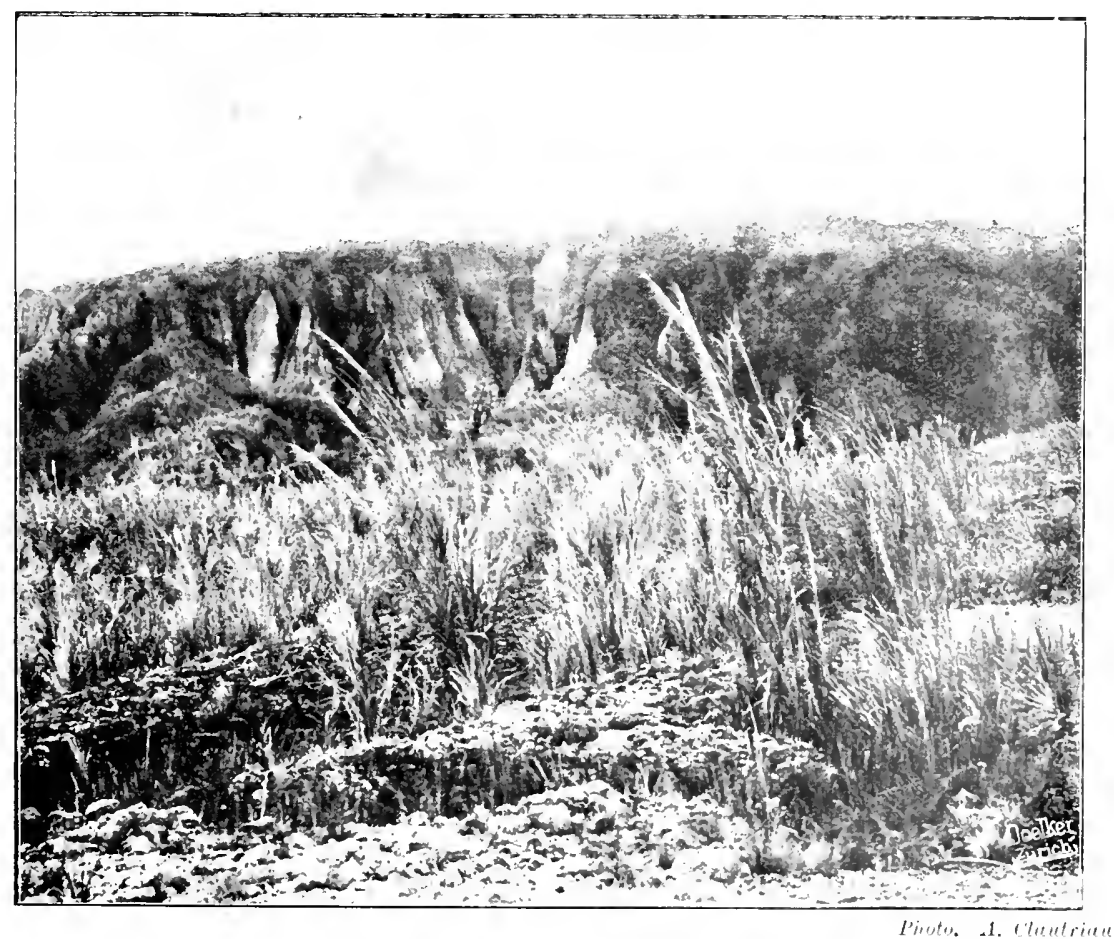

Fig. 12. Grass-stepne in the interior of Krakatan.

In the midale distance the first ravines and ridges on the slopes of Ralkata (p. 31). 

unique fashion a natural section of a volcanic cone (Pl. III., fig. 2). Verbeek, in his monograph on Krakatan (loc. cit. II. pp. 167, 496), gives the following account of this precipice as he saw it in October 1883 : "La paroi presque verticale de 832 mètres de hauteur, avec la mer bleu foncé et profonde de 300 mètres qui baigne son pied, fait sur tout le monde, par son caractère étrangement grandiose, une irrésistible impression. Dans l'effondrement de 1883 la montagne fut coupée presque verticalement par le milien, de sorte que la structure interne de ce volcan basaltique a été admirablement mise à découvert. Quand on se trouve au nord de la parroi à pic, on roit à gauche apparaitre au pied de la montagne, sous les couches basaltiques et en discordance avec elles, les bancs massifs de la roche ancienne ì tridymite et les conches de lapilli qui les recouvrent. Ces conches appartiennent au bord du cratère le plus ancien, et sont formées de la même roche que Verlaten Eiland et Lang Eiland ; en cela elles diffèrent beaucoup des autres conches du pic, qui consistent surtout en matières incohérentes, lapilli et fine cendre. Ces dernières couches alternent avec quelques bancs de lave et sont coupées transversalement par des filons lithoïdes. Elles sont de couleur brunâtre et tranchent fortement sur les matières ponceuses récentes, blanches ou gris clair, qui les recouvrent." Verbeek noticed a change in the appearance of the fiactured surface in August and September 1884: "La cendre gris clair monillée, qui à l'origine avait dégontté vers le bas et reconvert la surface en diver's points, surtont au milien, était maintenant en grande partie détachée par l'incessant effritement de la roche. La trainée de cendre grise étendue sur le sommet avait entièrement disparu, en laissant à découver't une grosse veine pierreuse, qu'on peut suive dans une direction presque verticale à travers les couches du pic, jusqu’à la moitié de la hauteur totale de la montagne, où elle se termine en $\mathrm{m}$ renflement lenticulaire." He adds to this description: "Il est vivement ì désirer que l'on réussisse bientôt à obtenir de cette paroi une bonne représentation photographique, sur laquelle les différentes couches et les différents filons soient nettement visibles. La tentative faite au mois de Septembre 1884 a échoué par l'insuffisance de la lumière. Comme il n'existe au nord de la falaise aucune terre assez rapprochée, on est réduit ì prendre la vue photographique ì bord d'un navire; l'exposition ne peut donc avoir qu'une très courte durée et dins ces conditions un éclairement intense de l'objet est absolument nécessaire." So far as I know none of the few visitors to Krakatan since this was written have had an opportunity of carrying out Verbeek's wish. I have therefore added to the photographs of the vegetation and plants which illustrate this account of the present state of the Krakatan 
flora the reproduction of one of the two views which the exceptionally favourable light and the stillness of the ship enabled me to obtain (Pl. III., fig. 2) ${ }^{1}$.

The face of the rock, like all the other parts of the island which are not covered with a thick carpet of vegetation, is continually undergoing change of form.

As we were on deck, taking our simple midday meal during the attractive voyage along the wild north coast, we suddenly became aware of an extraordinary phenomenon. Several small columns of smoke or steam appeared over a crater-like depression somewhat to the left of the highest peak, a spot rendered conspicuous by the absence of all trace of vegetation, and gathered into a light cloud over the mountain. Similar clouds rose above other points on the upper slopes. We asked ourselves: Is the volcanic activity of the island breaking out afresh? During the last few months and weeks news had reached us of volcanic outbursts (Vesuvius, Hawaii), of terrible earthquakes (San Francisco), and in Java itself the crater of Merapi had become active; in the highlands of Palang (Sumatra) the cone of Tandihat had broken out again after a long period of quiescence. Should we now have to take back to Batavia news of the reawakening of Krakatau? Fortunately our anxiety proved to be groundless. With the help of our field-glasses and the captain's telescope we were able to discover the canse of this disturbing phenomenon : stones of all sizes and masses of sand were continually being dislodged and the air-currents which they produced in their headlong descent raised clouds of dust which hung over the peak like masses of smoke. As we came nearer we could see some large stones bounding in gigantic leaps over the rocks and forming screes of detritus at the foot of the rock precipice. Some of these screes are shown in the photograph (Pl. III., fig. 2).

We landed in a broad bay, which is enclosed by the western part of the precipice and a steep promontory, "Zwarte Hoek," which was formerly the most westerly point of the old island. At this point the waves have washed up on to the shore a considerable quantity of pumice and ash, forming a small beach, the colonisation of which by plants has not yet proceeded so far as on the east and south-east shores of the island. The surface of sand sprinkled over with blocks of pumice and large masses of black lava is partially covered with a network of Ipomaea, Canavalia and Vigna, the shoots of which in the absence of competing rivals reach a length of 20 metres [ $65 \mathrm{ft}$.] (PI. IV., fig. 4). Young coconut palms occur here and there with seedlings of Barringtonia speciosa anchored in the sand by roots of 3 to 5 decimetres

1 See Addendum II., p. 72. 
long, while the tips of their stems are still enclosed in the fruit. Slender stems of Saccharum spontaneum with other grasses and Cyperaceae grow on the small cones of detritus at the foot of the rock-face in the loose stones of the lowest layers between the blocks of lava which cover the spurs of "Zwarte Hoek"; with these are associated plants of Casuarina, bushes of Scacvola Koenigii, with long panicles of white flowers hanging gracefully from the ends of branches above the rosettes of light green leaves, Sophora tomentosa, with bunches of legumes constricted like strings of beads, Desmodium umbellatum and other strand-species of Leguminosae. Plants of Spinifex squarrosus occur, and Neplerolepis exaltata, a Polypodiaceous fern with simply pinnate leaves, monopolises large areas. Graceful specimens of Lycopodium cernum grow in the shelter of the rocks, and Cassytha filiformis lives parasitically on a variety of hosts both at the foot of the rock-face and on the level ground. On the rocks we also collected delicate seedlings and numerous prothalli of Gymnogramme and, in addition to other ferns and Lycopods, Polypodium quercifolium, one of the few epiphytes in the Barringtonia forests, which grows here in clefts in the rocks, as in the neighbourhood of solfataras and craters of the volcanoes of Java. Other ferns among those which we found on the lava and pumice boulders grow epiphytically on the forest trees of Java and Sumatra. The conditions are approximately the same as in an epiphytic existence: a hard and comparatively dry substratum and intense sunlight have led the plants to return to a ground-habitat, and this is rendered easier by the fact that the struggle for a footing on the soil is not very severe.

The sun remained vertically above us in a clondless sky. Its burning and blinding rays on the white gromnd at the foot of the dark wall of rock produced an oppressive heat and a dazzling glare. Our servants were unable to follow us with bare feet over the hot sand and stayed behind on the edge of the shore which was cooled by the waves. We too were soon compelled to stop climbing over the loose blocks on the steep slopes of the Zwarte Hoek (black tongue of land) promontory, as it was impossible to bear our hands on the hot stones as we scrambled up the steep slopes. Before returning to the ship we rested in the partial shade aftorded by a fallen boulder. The bay in front of us with the small trim steamer and the vertical rockface glistening with coloured bands in the sunlight formed an impressive scene which made us forget our trouble and fatigue.

A third landing on the west coast of Krakatan proved impossible. We decided, therefore, to pay a short visit to one of the two neighbouring islands. Lang island which lay nearest to us, with its steep coast, is almost destitute of strand vegetation. Trees and shrubs are sparsely scattered on the broad grass-covered surfaces of 
the island. We could see from the ship that the vegetation of Verlaten island had, on the other hand, reached a much more advanced stage of development. On the east coast, which faced us, we noticed not less than seven forest-like clumps of Casuarina equisetifolia, which with groups of other trees and shrubs formed an almost continuous belt parallel to the coast. As we steered a northerly course towards Verlaten island, approximately in the region of the sunken hill of Danan, our obliging captain stopped the ship in order to enable me to take a photograph of the island of Krakatan showing the whole of the north coast (PI. III., fig. 1). Soundings taken as we neared Verlaten island showed that the figures on the charts no longer hold good, as considerable alterations have taken place in the contour of the sea-floor over the area of subsidence since the last observations were made. As the captain was anxious to get clear of the dangerous channel before nightfall he accompanied us to the shore in order to ensure our punctual return in the boat.

The regetation of Verlaten island, like that of Krakatan, consists of strand and inland floras. Here, as on Krakatau, fruits and seedlings of Nipa fruticans were found in the drift-zone associated with fruits and seeds of plants from the sandy and rocky beach, but there were no older individuals of this swamp-loving palm nor any other representatives of the Mangrove flora. The strand-flora of Verlaten island consists of members of the Pes-caprae and Barringtonia plantformations.

Between the single clumps of Casuarinas, in which many of the stems are thickly draped with climbing plants, Vitis trifolia and Mucuna pruriens, we noticed strand trees growing in company with Barringtonia, such as Terminalia and Calophyllem, Leguminosae and Pandanus litoralis. The leaves of Tournefortia argentea, to which a thick felt of hairs gives a silver-grey colour, were visible from a distance. Among widely distributed strand-plants occurred Erythrina indica, the Verbenaceous species Premna foetida, and two Rubiaceae, Morinda citrifolia, and Guettarda speciosa. Somewhat further inland we found several species of Ficus, coconut palms and another cultivated plant, Carica Papaya. Their seeds may have been brought to the island by birds or flying foxes which eagerly search for the soft fruits of the Papaw, or possibly this plant was introduced by man, as some years ago Verlaten island was inhabited for a time by a party of surveyors. On the other hand, Melastoma polyanthum, a shrub with leathery leaves, large violet flowers and juicy berries which are eaten by several kinds of birds, is a widely spread species over the hills and valleys of Java, and has certainly been transported endozoically to this new locality by the agency of birds. 
The tall grasses, Cyperaceae, ferns and Composites have spread through clearings in the strand-forest to the shore, reaching as far as the earpet-like mass of Ipomaea Pes-caprae, Spinifex, Ischaemum, Vigna, Canaralia and Cassytha. The interior of the island, as in Krakatan, is partially covered with an open and in part with a closed formation of grasses, Cyperaccae, and ferns interspersed with climbing plants, Composites and orchids and with scattered trees and shrubs. In 1897 fifteen species of phancrogams and vascular cryptogams were found on Verlaten island. Our collection, made by two of us during a visit of barely one hour, consisted of 42 species, seven of which (Vitex Negundo, Carica Papaya, Colubrina asiatica, Caesalpinia Bondueella, Muenna pruriens, Ximenia americana, Ficus hirta) had not been previously found on Krakatau. It is highly probable that a longer visit to Verlaten island would have yielded a flora very similar in composition to that of Krakatau. The data we obtained are amply sufficient to demonstrate that the colonisation of Verlaten island has been accomplished in the same way and by means of the same agencies as in the ease of the neighbouring island of Krakatau.

Shortly after 5 o'clock we were again on board the steamer. Before sunset the whole group of islands was left behind us and the "Snip," making a wide sweep to the north, threading its way between Sebesi and Seboekoe, carried us into the island-studded Java Sea and next day to Tandjong Priok, the harbour of Batavia.

\section{The present composition of the flora of the island of Krakatau.}

The vegetation of Krakatau and Verlaten island has in the last ten years become considerably richer, in places even luxuriant. The results of our excursion enabled us to add considerably to the plantlist of the group of islands. The present flora of Krakatan includes representatives of all divisions of the plant-kingdom : Hyxomycetes, Bacteria, Algae, Fungi, Liverworts, Mosses, Ferns, Gymnosperms, and Angiosperms. The total number of species collected in the group of islands during the excursions made in 1886, 1897 and 1906 reached 137.

In the following list the species obtained on the three occasions are arranged according to families and classes, beginning with the Angiospermae dicotyledonecue. The middle column shows on which of the three islands the plants were found and when $(1836,1897 \mathrm{or}$ 1906) the records were made. (Abbreviations: K.=Krakatan; $\mathrm{V} .=$ Verlaten island ; L. = Lang island $; \mathrm{I}=$ visit in June 1886 ; $2=$ visit in March $1897 ; 3=$ visit in April 1906.) 
The information in regard to the area of distribution of the phanerogams and vascular cryptogams is taken from the Floras and systematic works mentioned below.

\section{Angiospermae Dieotyledoneae.}

Fam. Compositae.

1. Blunea balsamifera D.C.

K. 2.3 ; V. 3 ; Coast vegetation of India and

L. 2.

2. Blumea hicraeifolia D.C.

K. 2,3 .

3. Conyza angustifolia Ham.

4. Conyza indica Miq.

K. $1 .(?) 3$.

K. 1.3.

5. Emilia sonchifolia (L.) I.C.

K. 2.

6. Erechthites hicracifolia (L.) K. 3 ; V. 3. Raf.

7. Pluchea indiea (L.) Less.

K. 2. 3 ; L. 2

8. Senecio spec.

K. 1.

9. Vernonia cinerca (L.) Less.

K. 2. 3.

10. Wedelia asperrima Bocrl.

\section{K. $2 ; \mathrm{L} .2$.}

Further India and the islands of the Indian Ocean to the Plilippines and Australia.

India and Further India, Malay Archipcl., Plilippines, Australia, tropical and subtropical Africa.

India, Malay Archipclago.

Further India, Malay Archipelago, S. China.

Widely spread in the tropics of the Old World and naturalised in the New World.

All the warmer and temperate regions of America and introduced into the old World.

Videly distributed from East India to Australia.

Genus represented by several species in the Malay Archipelago.

Abundant in the tropies of the OId World.

Java, Timor.

1. Blume, C. L. Bijdragen tot de Flora van Nederlandsch Indie. Batavia, 1825. — Enumeratio Plantarun Javae et Insularum adjacentium. Haag, 1830. Flora Javae, 1829.

2. Boerlage, J. G. Handleiding tot de Flora van Nederlandsch Indie I.-III. Leiden, 1890-1900.

3. Christ, H. Die Farnkrïuter der Erde. Jena, 1897.

4. Engler-Prantl. Natïrliehe Pflanzenfamilien. I. Teil, 4. Abteilg. bis Iv. Teil, 5. Abteilg.

5. Engler, A. Syllabus der Pflanzenfamilien. 4. Auf. Berlin, 1904.

6. Hooker, J. D. Flora of British India. Vol. I.-VII. London, 1875-97. Hooker, W. J. Species filieum. Vol. I.-V. London, 1846-64.

7. Koorders, S. H. Notizen über die Planerogamenflora von Java (Iv.). Natuurkundig Tijdsehrift voor Nederlandsch-Indië. Bd. 60. 1901.

8. Koorders, S. H., u. Th. Valeton. Bijdragen t. d. Kennis d. Boomsorten of Java. No. I.-X. 1873-1904.

9. Miquel, F. A. W. Flora v. Nederlandsch Indie mit Suppl. : Prodromus florae Sumatranae. Amsterdam, 1855-60.

10. Raciborski, M. Die Pteridophyten d. Flora v. Buitenzorg. Leiden, 1898. 
11. Wedelia glabrata $B$, et $H$.

12. Wedelia scabriuscula Boerl.

13. Wollastonia spec.

Fam. Goodeniaceae.

14. Scacvola Koenigii Vahl.

Fam. Cucurbitaceae.

15. Trichosantlies tricuspidata Lour.

Fam. Rubiaceae.

16. Guettarda speciosa L.

17. Morinda citrifolia L.

Fam. Labiatae.

18. Hyptis brevipes Poit.

Fam. Verbenaceae.

19. Clerodendron incrme Gaertı. K. 3.

20. Premna foetida Reinw.

21. Vitex Negundo L.

Fam. Borraginaceae.

22. Tournefortia argentea Is.

Fam. Convolvulaceae.

23. Calonyction asperum Choisy

24. Ipomaea denticulata Choisy

K. 3 .

K. 3 .

25. Ipomaea Pes-caprac $[=$ I. biloba $]$

Sw.

Fam. Asclepiadaceae.

26. Cynanchum Blumei B. et H. K. 3.

Fam. Apocynaceae.

27. Cerbera Odollam Gaertu.

K. 1 .

K. 3 .
K. l. (?) $3 . \quad$ Java, Timor.

K. 2 ; L. 2 Malay Archipclago, Java.

K. 1. 2. 3; V.2. Tropical Fast $\Lambda$ sia, Malay Archi3 ; L. 2.

pelago, P’olynesia.

K. $3 ; \mathrm{V} .3$.

From the Himalayas to Ceylon and Singapore, Malay Archipelago (Java and Sumatra), China, N. Australia.

K. 3; V. 3. Almost all tropical coasts.

K. 2. 3; V. 3; Tropical E. Asia, trop. Australia, L. 2. Polynesia, in the interior (cultivated).

Tropical America, introduced on the coast of Africa and tropical Asia.

India and Further India, Ceylon, Malay Archipelago, New Guinea, N. Australia.

K. 3; V. 3. Java, Borneo, Moluccas.

V. 3. Nicobar Island, Ceylon, India, Malay Archipelago to the Philippines.

K. 1. 3; V. 3 . Ceylon, Further India, Nicobar I., Malay Archipelago, New Guinea, trop. Australia.

Abundant in the Malay Archipelago.

Ceylon, Further India, Malay Archipclago, Australia.

All tropical coasts.

3 ; L. 2.

Sumatra, Java.

K. 1.2.3; V. 3; Tropical East Asia, Malay Archi-

L. $2 . \quad$ pelago, Australia.

11. Smith, J. J. Jie Orchideen v. Java. Leiden, 1905.

12. Schimper, A. F. W. Die Indomalayische Strandflora. Jena, 1891. 
Fam. Melastomataceae.

28. Melastoma polyanthum Bl. K. 3; V. 2. 3. East India, China, Malay ArchiFam. Myrtaceae.

29. Eugenia speciosa L. (?)

L. 2.

Fam. Combretaceae.

30. Terminalia Catappa L.

Fam. Lecythidaceae.

K. 2. 3; V. 2. 3; Malay A rchipelago, Keeling I., L. $2 . \quad$ Polynesia, New Guinea.

31. Barringtonia speciosa Forst. K. 2. 3; V. 3; Ceylon, Andaman I., Singapore, L. 2. Malay A rchipelago, trop. A ustralia.

32. Barringtonia Vriesei l'eysm. L. 2. Java (Prov. Bantam). et Binnend.

Fam. Caricaceac.

33. Carica Papaya L.

V. 3.

Spread from America as a cultivated plant over the whole of the tropics.

Fam. Guttiferae.

34. Calophyllum Inophyllum L. K. 1. 3; V. 3 ; India, N. Australia, Polynesia. Fam. Sterculiaceae.

L. 2.

35. Melochia arborea Bl. K. $3 ;$ V. 3.

36. Melochiaindica(Hontt.) A.Gr. K. 2 . Malay A rchipelago.

Fam. Malvaceae.

37. Hibiscus tiliaceus L.

K. $2.3 ;$ V. 3 ; All tropical coasts.

L. 2.

Fam. Vituceae.

38. Vitis trifolia L. K. 3.

Fam. Rhamnaceae.

39. Colubrinaasiatica(L.)Brongn. V. 3.

Fam. Sapindaceae.

40. Dodonaea viscosa $\mathrm{L}$.

K. 3 .

Fam. Anacardiaceae.

41. Spondias mangifera Willd.

K. 3 .

India and Further India, CeyIon, Malay Peninsula, Java, Sumatra.

India and Further India, Ceylon, Java, Borneo, trop. Australia.

Fam. Euphorbiaceae.

42. Euphorbia Atoto Forst.

43. Euphorbia pilulifera $\mathrm{L}$.

K. 3 ; V. $3 . \quad$ Trop. and subtrop. E. Asia.

K. 2 ; L. 2 Cosmopolitan in tropical and subtropical regions (also inland).

Fam. Meliaceae.

Tropical coast of S. Africa to Australia and New Zealand, also as an inland plant.

Indo-Malayan region.

44. Carapa obovata Bl.

K. 3.

Ceylon, Malay Ar'chipelago. 
Fam. Leguminosae.

45. Albizzia stipulata Boiv.
$\begin{aligned} & \text { 46. Caesalpinia Bonducella } \\ & \text { Roxb. }\end{aligned}$

47. Cassia siamea Lam.

45. Canavalia obtusifolia D.C.

49. Derris uliginosa Lour.

50. Desmodium umbellatum D.C.

51. Entada Pursaetha D.C.

52. Erythrina indica Lam.

53. Erythrina ovalifolia Roxb.

54. Indigofera Teysmanni Miq.

55. Mucuna pruriens D.C.

56. Pongamia glabra Vent.

57. Pithecolobium moniliferum Bth.

58. Sophora tomentosa L.

59. Vigna lutea (Sw.) A. Gray

60. Vigna lutcola (Jacq.) Benth. Fam. Hernandiaceae.

61. Hernandia peltata Meissn.

Fam. Lauraceae.

62. Cassytha filiformis L.

Fan. Olacaceae.

63. Ximenia americana $L$.

Fam. Urticaceae.

64. Pipturus incanus Wedd.

Fam. Moraceae.

65. Ficus fistulosa Reinw.

66. Ficus fulva Reinw.

67. Ficus hirta Vahl.

68. Ficus hispida L.

69. Ficus leucantatoma Poir.

70. Ficus toxicaria L.

V. 3.

V. 3.

V. 3 .

L. 2.
K. 3.

Trop. and sulttrop. Asia, Malay Archipelago.

All tropical coasts.

Further India, Malay Archipelago.

K. 2.3; V. 2.3; All tropical consts.

L. 2.

K. 3.

Trop. E. Asia to Hongkong and Polynesia.

K. 3; V.3; L. 2. Trop. E. Asia, Australia.

V. 2. Widely spread in the tropics of both hemispheres.

K. 1. (?) 3 ; V. 3; Indian region (also inland).

L. 2.

V. 3 ; L. 2.

K. 3.

Sumatra.

Tropics of both hemispheres.

K. 3 ; V. $3 . \quad$ Indian region.

K. 3.

K.3; V.3; L. 2. All tropical coasts.

K. 2. 3; V. 3 ; Andaman Islands, Malay Archi-

L. 2 . pelago, trop. Australia.

K. 2; I. 2. Cosmopolitan in the tropics of the Cape and the Argentine.

K. 1.3.

Tropical E. Asia, New Guinca, Polynesia.

K. 2. 3 ; V. 2. All tropical coasts (also inland). 3 ; L. 2.

Tropical coasts of the old and New World.

K. 3; V. 3. Malay Archipelago, Polynesia (also inland).

K. 3.

K. 3 ; V. 3.

Perak, Penang, Singapore, Malay Archipelago (Java).

Malay Archipelago, China.

India, Further India, Ceylon, Malay Archipelago, China, A ustralia.

V. 3 ; L. 2 .

K. 2; L. 2. Malay Archipelago, Java and Sumatra. 
Fam. Ulmaceae.

71. Trema amboinensis $\mathrm{Bl}$.

K. 3.

Subtrop. and trop. Asia and

Fam. Casuarinaceae. Australia.

72. Casuarina equisetifolia Forst. K. 2.3; V.2.3; Further India, Malay ArchiL. 2 . pelago (also inland), N. Australia.

\section{Angiospermae Monocotyledoneae.}

Fam. Orchidaceae.

73. Arundina speciosa $\mathrm{Bl}$

K. 2.3.

Very common in Java in sunny places (volcanoes!), Borneo, Sumatra, Malacca, East India.

74. Cymbidium Finlaysonianum K. 3. Lindl.

Malay Archipel. (Java, Borneo, Sumatra, Celebes, Riouw, Singapore, Malay Peninsula).

75. Phajus spec.

76. Spathoglottis plicata Bl.

77. Vanda Sulingi Bl. Fan. Palmae.

78. Cocos nucifera $\mathrm{L}$.

Fam. Cyperaceae.

79. Cyperus digitatus Roxb.

80. Fimbristylis spathacea Roth

81. Mariscus umbellatus Vahl.

82. Remirea maritima Aubl. Fam. Gramineae.

83. Gymnothrix elegans Büse

84. Imperata arundinacea Cyr.

85. Ischaemum muticum $\mathrm{L}$.

86. Pennisetum elegans J.K. K. $2 ;$ L. 2 .

K. $2.3 ;$ V. 3 L. 2 .

L. 2.

K. 3;V.3; L.2. All tropical coasts.

K. 1. (?) 2; V.2. Widely spread in the tropics, India, Ceylon, Penang.

K. 1. (!) 2. 3. Ceylon, Further India, India, V. 3; L. 2 . Singapore.

K. 3 .

K. 3 ; L. 2 .

From Africa to New Guinea, Java, Sumatra.

All tropical coasts.

K. 1. 2; V. 2; Java.

L. 2.

K. 2. 3 ; L. 2. Cosmopolitan, Alang-Alang [ Imperata arundinacea] fields in the Malay Archipelago.

K. 2.3 ; V. 3 ; Malay Archipelago, Burmah. L. 2 .

K. 3 ; V. $3 . \quad$ Trop. America, Africa, India.

87. Phragmites Roxburghii Stend. K. 1. 2; V. 2; Trop. Africa, India, Ceylon, L. $2 . \quad$ Sumatra, Java, Australia.

8s. Pogonatherum crinitum Trin. K. 2.3 ; V. 3 ; India and Further India, Malay

L. 2. Archipelago.

89. Saccharum spontaneum L.
K. 2.3 ; V. 3 ; Tropics of the Old World; occurs L. 2. in the Alang-Alang [Imperata arundinacea] fields of the Malay Archipelago. 
90. Spinifex squarrosus L.

K. 2. 3; V.2.3; India and Further India, Malay Fam. Pandanaceae.
L. 2 .
Archipelago.

91. Pandanus spec. (littoralis Jungh. ?).

K. 2.3; V.2.3. Several species in the IndoMalayan strand-formation, particularly common in Java and on the coral islands of the Java Sea.

Fam. Cycadaceae.

92. Cycas circinalis L.

Fam. Lycopodiaceae.

93. Lycopodium cernumm L. K. 2. 3.

Fam. Ophioglossaceae.

94. Ophioglossum moluecanum K. 2. Schlecht

Fam. Polypodiaceae.

95. Acrostichnm aureum $\mathrm{L}$.

96. Acrostichum seandens J. Sm. K. 1. 2.

97. Aspidium vile Kze.

95. Bleclnum orientale L.

99. Gymnogramme calomelanos (L.) Kaulf.

100. Nephrodium calcaratum(Bl.) Hook.

101. Nephrodium eucullatum(Bl.) Bak.

102. Nephrodium flaceidum Hook.

103. Nephrolepis exaltata Schott

K. 2.

K. $1.2 ;$ V. 2

K. 1.
India and Further India, Malay Archipelago (also inland).

\section{Pteridophyta.}

Islands and coast of the tropical zone ; especially in the Malay Archipelago.

Hills and lower forest-zone of Java.

K. 1. 2. 3; V.2. Mangrove swamps and Nipaformation of all tropical countries.

Mangrove- and Barringtoniaformation. From N. India and S. China to N. Australia.

Xerophilous; volcanoes of Java. From N. India and S. China to Polynesia, Now Guinea, and Australia.

K.1.2.3; V.3. Tropics of the New and Old World.

From E. Himalayas extending to the south of S. China; Malayan region.

Malay Archirelago; plains and ligh ground.

Malay Archipelago (Java).

Epiphytic and ground-fern, from $N$. India and Japan to Australia and New Zealand; Africa and America.

104. Onyehium auratum Kaulf. K. 1.

Himalayas to the Philippines.

105. Polypodium quercifolium L. K. 2. 3.

N. India and S. China to Ceylon, Malay Archipelago.

106. Pteris aquilina $\mathrm{L}$.

K. 1. 2 . 
107. Pteris longifolia L.

108. Pteris marginata Bory

Fam. Anthocerotaceae.

109. Anthoceros spec.

Fam. Bartramiaceae.

110. Philonotis secmonda (Dz. et K. 1. (?) 3. Mlb.) v. d. B, et Lac.

Fam. Bryaceae.

111. Bryum eoronatum Schwaegr. K. 1. (?) 3 .

Fam. Agaricineae.

Eumycetes.

112. Hygrophorus spec.

K. 2 .

Fam. Polyporaceae.

113. Polystictns sanguineus (L.) K. 3. Fries.

114. Polystictus hydnoides

Fam. Bacillariaceae.

115. Navieula spec.

K. 3.

116. Encyonema ventricosum Kütz.

117. Nitzsehia sigma (Kütz.) Sm. K. 2.

118. Cystopleura gibba (Ehrenb.) K. 2. Kunze

119. Cystopleura

(Ehrenb.) Kunze var. producta Gruu.

Fam. Chroococcaceae.

Schi:ophyta.

120. Aphanothece Castagnei K. 2. (Breb.) Rabh.

121. Gloeothece rupestris (Lyngb.) K. 2. Bor.

Fam. Oscillatoriaceae.

122. Lyngbya Verbeekiana Trenb K. 1.

123. Lyngbya minutissima Tr. K. J.

124. Lyngbya intermedia Tr. K. 1.

125. Nicrocoleus chlonoplastesThr. K. 2.

126. Oscillatoria amphibia Ag. K. 2.

127. Sehizothrix vaginata Gom. K. 2.

128. Symploca spec. K. 1 .
World; very widely spread in Java.

From E. India and Ceylon through the Malay region to N. Australia. 
Fam. Nostocaceae.

129. Anabaena spec.

K. 1 .

Fam. Scytonemaceae.

130. Scytonema mirabile Boss. K. 2.

131. Tolypothrix spec. K. 1.

Fam. Bacteriaceae.

132. Bacterium radicicola Beye- K. 3. rinck

133. Bacterium Krakataui De K. 3. Kruyff

134. Bacillus Mycoides Flügge K. 3.

135. Bacillus Moiré (B. mega- K. 3. therium de Bary?)

136. Bacillus fluorescens liquac- K. 3. faciens

Fam. Physaraceae.

Myxothallophyta.

137. Physarum cinereum (Batsch) K. 2.

Pers.

The majority of the species which have found their way to the island during the last ten years belong to the phanerogamous plants, which now give the characteristic facies not only to the strand vegetation but to that on the plains and mountain slopes. While the ferns have not materially increased in number, the total number of phanerogams (15 species in 1886) has risen from $56^{1}$ in the year 1897 to 92 in April 1906 . The additional species are almost equally distributed between the strand and inland flora.

The following species belong exclusively or mainly to the strandzone of Krakatau and Verlaten island :

* Blumea balsamifera D.C. Conyza angustifolia Ham. Pluchea indica (L.) Less.

* Wedelia glabrata B. et $\mathrm{H}$.

Wollastonia spec.

* +Guettarda speciosa L.

†Hyptis brevipes Poit.

* +Premma foetida Reinw.

* †Tournefortia argentea L.

†Ipomaea denticulata Choisy

Cynanchum Blumei B. et $\mathrm{H}$.

Eugenia speciosa L.
Blumea hieracifolia D.C.

†Conyza indica Miq.

Wedelia asperrima Boerl.

Wedelia seabrinscula Boerl.

* †Scaevola Koenigii Vahl.

* +Morinda citrifolia L.

* +Clerodendron inerme Gaertn.

*Vitex Negundo L.

* Calonyetion asperum Choisy

* Ipomaea Pes-caprae Sw.

* Cerbera Odollam Gaertı.

* Terminalia Catappa L.

${ }^{1}$ Penzig gives 53 as the number; he did not include in the list of the plants obtained in 1897 the two species of Conyza and Senecio sp. found by Treub. 
* †Barringtonia speciosa Forst.

* †Calophyllum Inophyllum L. Melochia indica (Houtt.) A. Gr.

Vitis trifolia L.

* †Dodlonaea viscosa L.

* Euphorbia Atoto Forst.

+Carapa obovata Bl.

Cassia siamea Lam.

†Derris uliginosa Lour.

Entada Pursaetha D.C.

†Erythrima ovalifolia Roxb.

Mucuna pruriens D.C.

Pithecolobium moniliferum Bth.

+Vigna lutea (Sw.) A. Gray

* +Hernandia peltata Meissn.

†Ximenia americana L.

* +Casuarina equisetifolia Forst.

Cyperus digitatus Roxb.

†Remirea maritima Aubl.

* †Spinifex squarrosus L.

* † Cycas circinalis L.

* †Polypodium quercifolium L.
Barringtonia Vriesei Teysm. et Binnend.

Melochia arborea Bl.

* +Hibiscus tiliacens L.

* + Colubrina asiatica (L.) Brongu.

†Spondias mangifera Willd.

† Euphorbia pilulifera L.

* †Caesalpinia Bonducella (L.) Roxb.

* † Canavalia obtusifolia D.C.

* +Desmodium umbellatum D.C.

* Errythrina indica Lam.

Indigofera Teysmanni Miq.

* †Pougamia glabra Vent.

* +Sophora tomentosa L.

†Vigna luteola (Jacq.) Benth.

* +Cassytha filiformis L.

Pipturus incanus IVedd.

* +Coeos nucifera L.

* Fimbristylis spathacea Roth

* Ischaenum muticum L.

* Pandanus spec.

* $†$ Acrostichum aureum L.

Two-thirds of the strand-flora of the island of Krakatau are made up of species which are ubiquitous on tropical coasts. Of the 67 species in the above list, 42 (indicated by $\dagger$ ) are included as typical strand-plants in the lists given by Schimper ${ }^{1}$ and Hemsley ${ }^{2}$ : 35 of these are widely spread and abundant beyond the Malay Archipelago and may occur over the whole tropical zone. The importance of these plants in the strand-flora on the coast of the Sunda Strait region is illustrated by an examination of the lists of the species which we collected on Edam, at Vlakke Hoek (Sumatra) and Java's First Point (pp. 12-14, 17, 18, 24, 25).

Of the 36 halophytes from Edam, indicated by,+ 18 occur on the Krakatan islands; the islands possess 21 of these widely spread species in common with the strand-flora of Vlakke Hoek and 14 with that of Java's First Point. An equally well marked agreement is shown by a comparison with other localities on the coasts of Java and Sumatra,

1 Schimper, A. F. W. Die Indomalayische Strandflora, p. 100.

${ }^{2}$ Hemsley, B. W. Report of the Present State of Knowledge of Various Insular Floras, p. 42. 
with the islands of the Java Sea or the Sunda Strait region. Of the 17 strand-plants which Guppy ${ }^{1}$ records from the localities which he visited on the south-west coast of Java, 14 belong to the Krakatan flora. The Keeling or Cocos islands (south-east of the Sunda Strait in lat. $12^{\circ} \mathrm{S}$. and $98^{\circ}$ E. long.), visited by Darwin ${ }^{2}$ (1836), Forbes ${ }^{3}$ (1878), and Guppy (1888), possess 18 representatives of the Krakatan flora out of a total of about 30 phanerogams. The five localities together (Edam, Vlakke Hoek, Java's First Point, S. W. coast of Java and the Cocos islands) include 36 species (shown by $*$ † or * in the list) which are represented in the strand-flora of Krakatau. The 25 additional species, which occur in the new strand-flora of Krakatau, belong to genera other species of which are mentioned as typical strand-plants in the lists of Schimper and Hemsley.

In the interior of the island, on the gently sloping beach and on the sides of the cone, the following phanerogams and vascular cryptogams occur with several species which are also included in the list of strand-plants.

Emilia sonchifolia (L.) D.C.

Senecio spec.

Trichosanthes tricuspidata Lour.

Carica Papaya L.

Ficus fistulosa Reinw.

Ficus hirta Vahl.

Ficus leucantatoma Poir.

Trema amboinensis $\mathrm{Bl}$.

Cymbidium Finlaysonianum Lindl.

Spathoglottis plicata Bl.

Mariscus umbellatus Vahl.

Imperata arundinacea Cyr.

Phragmites Roxburghii Stend.

Saccharum spontaneum L.

Lycopodium cernuum $\mathrm{L}$.

Acrostichum scandens J. Sm. Blechnum orientale L.
Erechthites hieracifolia (L.) Raf. Vernonia cinerea (L.) Less.

Melastoma polyanthum BI.

Albizzia stipulata Boiv.

Ficus fulva Reinw.

Ficus hispida L.

Ficus toxicaria L.

Arundina speciosa $\mathrm{Bl}$.

Phajus spec.

Vanda Sulingi Bl.

Gymmothrix elegans Biise

Pennisetum elegans I.K.

Pogonatherum crinitum Trin.

Ophioglossum moluccanum

Schlecht

Aspidium vile Kze.

Gymnogramme calomelanos

Kaulf.

${ }^{1}$ Guppy, H. B. The dispersal of Plants, as illustrated by the Flora of Keding or Cocos Islands. (Reprint, 1590, p. 30.)

2 The plants eollected by Darwin were determined by J. S. Henslow : "Florula Keelingensis," Ann. Mag. Nat. Hist., 1838, Vol. I. pp. 337-347. The list is given also in the Challenger Reports, Botany, Vol. I. Pt. iii. p. 113.

${ }^{3}$ Forbes, H. O. A Naturalist's Wanderings in the Eastern Archipelago, 1878-83. London, 1885. 
Nephrodium calcaratum(Bl.)Hook. Nephrodium cncullatum Bak.

Nephrodium flaccidum Hook. Onychium auratum Kaulf. Pteris longifolia $\mathrm{L}$. Nephrolepis exaltata Schott Pteris aquilina L. Pteris marginata Bory

The plants in this list, as the notes appended to the list of the whole flora show, are also characterised by a wide distribution. Some are cosmopolitan and, as in the case of Lycopodium cermum, Pteris aquilina, and others, are met with in all parts of the world. Others are spread over the tropics of the Old World (Emilia sonchifolia, Vernonia cinerea, Saccharum spontaneum, etc.), occurring throughout the whole of subtropical and tropical Asia or in the Malay Archipelago region. Within their respective distribution-areas they belong to the commonest plants and to such as grow indifferently in a great variety of habitats. These constituents of the new Krakatau flora owe their occurrence in the new habitat, as also their wide distribution, chiefly to the efficient adaptation of their fruits and seeds to distant transport.

\section{The biological conditions on Krakatau.}

The new flora of Krakatan demonstrates in a remarkable degree how quickly plants are able to take possession of a sterilised region even under the most unfavourable conditions. It is by the cooperation of a variety of factors that living germs, which have been carried by some agency or other to new land like Krakatan, are able to continue their existence and even to produce new plants. A large proportion of the germs which reach the new land do not survive because they fail to find ground suited to their development or because of unfavourable climatic conditions. Seeds and fruits of other plants, for which the conditions of the new habitat may be congenial, have lost the power of germination during transport either by desiccation or by excessive wetting, or they may retain the power to germinate for a short time only after falling from the tree and this has been lost in the course of their long voyage. Many of the seeds which are capable of germination and further development are destroyed by animals either before or during germination, or they may have been killed by changes in the substratum. In the early stages of the colonisation of fresh ground, the struggle with other plants for space and light may be disregarded.

On the other hand, a plant which has begun to grow requires such conditions as are favourable to the fertilisation of its flowers and the 
ripening of its fruits. Anemophilons plants which have obtained a footing on the ground will presumably produce a large crop of fruit and thus be in a better position, from the point of view of dispersal over the virgin soil, as compared with others with special contrivances for the pollination of their flowers by particular inseets which are unlikely to exist on a newly formed and isolated land-area. For the same reason dioecious species often fare badly in regard to dispersal. If only a single individual of such a species oceurs (as in the case of Cycas on Krakatan), or if a few are spread over a wide area, the production of fruit is clearly impossible. Plants of this class will therefore cease to form a part of the flora if new seeds, capable of germinating and produeing individuals of the opposite sex, do not reach the island before the death of the first arrival.

During the first few years of the colonisation of Krakatau the injurious influences of intense insolation and of rumning water must have acted as a serious eheck to the pioneers of vegetation on the fields of pumice and voleanic ash. There is comparatively little rain in the dry season of the year which, presumably at Krakatau, as at Batavia and other places on the north-west coast of Java, continues with the south-east monsoon approximately from May to September. Every day, also on elear days in the rainy season, the temperature of the ground considerably exceeds the maximum for the growth and germination of the majority of plants. The total rainfall of the island ${ }^{1}$ probably amounts to $2 \frac{1}{2}$ metres [98 inches] a year, the greater part falling between Deeember and Narch. The denuding force of the streams after each heavy downpour of rain, more especially during the first few years after the volcanic outburst, produced surface-changes and many seeds must have been swept away with the loose superficial rock; many seedlings which had developed despite unfarourable conditions must have been "torn up or buried in sediment.

The chemical composition of the substratum and its physical properties were, on the other hand, not so unfavourable to plantcolonisation as one would expect. The analyses of the ash and pumice made by C. Winkler and given by Verbeek (loc. cit. II. p. 305) show that they contain a sufficient quantity of all the inorganic salts necessary for a plant (excluding nitrogenous and phosphoruscontaining eompounds) and, a fact of primary importance in plant-life, the salts occur, in part at least, in a soluble form. The following results

1 In West Java the average from 24 stations is $276 \mathrm{~cm}$., in Fast Sumatra the average of 10 stations is $264 \mathrm{~cm}$. ; for the whole Arehipelago the mean rainfill may be reckoned at $252 \mathrm{~cm}$. 
are given for the ash from the uppermost layers formed during the first eruption $(a)$ and for the light coloured pumice, etc. $(b)$ :

(a)

$\mathrm{SiO}_{2}$
$\mathrm{TiO}_{2}$
$\mathrm{Al}_{2} \mathrm{O}_{3}$
$\mathrm{Fe}_{2} \mathrm{O}_{3}$
$\mathrm{FeO}$
$\mathrm{MnO}$
$\mathrm{CaO}$
$\mathrm{MgO}$
$\mathrm{K}_{2} \mathrm{O}$
$\mathrm{Na}_{2} \mathrm{O}$
$\mathrm{CaSO}_{4}$
$\mathrm{Organic}$
$\mathrm{TaCl} \mathrm{Cl}$
$\mathrm{KCl} \mathrm{Na}_{2} \mathrm{SO}_{4}$
$\mathrm{CaSO}_{4}$
$\mathrm{FeSO}_{4}$

$\left.\begin{array}{r}60 \cdot 13 \\ 1 \cdot 10 \\ 17 \cdot 41 \\ 4 \cdot 30 \\ 1 \cdot 68 \\ 0 \cdot 40 \\ 3 \cdot 36 \\ 2 \cdot 27 \\ 2 \cdot 46 \\ 4 \cdot 88 \\ 1 \cdot 57 \\ \text { traces }\end{array}\right\}$

$\left.\begin{array}{r}0.75 \\ \text { traces } \\ 0.22 \\ 0.11 \\ 0.03\end{array}\right\} \begin{gathered}\text { Soluble in } \\ \text { water } \\ 1.11 \%\end{gathered}$

(b)

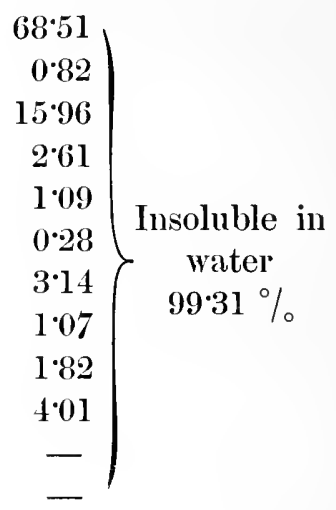

1.09
traces
$\begin{gathered}0.22 \\ 0.03\end{gathered}$$\quad \begin{gathered}\text { Soluble in } \\ \text { water } \\ 1.34 \%\end{gathered}$

The soluble substances are derived chiefly from sea-water which percolated through the surface to the reservoir of lava or was driven into the crater at the time of the explosion, and in the course of subsequent eruptions became mixed with the volcanic ash. Possibly some of the gypsum has not eome from sea-water but from older strata of the volcano; this hypothesis derives support from the fact that the insoluble portion of the ash contains a considerable amount of anhydrite. Among the other components of sea-water magnesium ehloride is not represented in the soluble constitnents of the ash ; it is probable that by contact with aqueous vapour at a high temperature this was converted into the insoluble oxide of magnesium. The small amount of bromine and iodine in sea-water (about $\frac{1}{4} \%$ ) may well explain the absence of these elements both from the ash and the pumice.

Some of the inorganic salts required for the nutrition of plants were present in the material produced by the eruption in more than sufficient quantity and in a soluble and available form. Such substances as are unrepresented in the volcanic material may have been brought in the form of dust in the same way as organic germs are carried to islands by water and by wind. Moreover, tidal waves and 
waves produced during storms constantly wash up on to the beach large quantities of organic material, sea-weeds and marine animals, so that a plentifully supplied nidus would always be found at a distance of 50 metres or more from the coast; from this the underlying porous pumice and ashes would derive organic and inorganic products of decay.

As regards the establishment of conditions favourable for plantlife in the interior of the island, other sourees must be considered; clouds of dust blown by local winds from the shore; minute particles of inorganic and organic substances brought by the monsoon together with micro-organisms and the spores of mosses and ferns; also the seeds of phanerogamous plants; and lastly, the nitric and nitrous acids, which eonstitute the ehief supply of nitrogenous food, provided by rain. We are justified in assuming that in equatorial regions the oxidation of nitrogen to nitrates and nitrous acid takes place under the influence of electrical discharges, which accompany the almost daily storms, at least with as much activity if not with much greater activity than with us.

Despite the comparatively small amount ${ }^{1}$ of nitrogenous material which is added to the ground by rain in a single year, it would however be sufficient, together with the salts and traces of organic matter contained in the ash, to support even in the first years after the eruption a rich flora of micro-organisms.

Three years after the volcanic outburst dark green gelatinous layers of "blue-green" algae were found on the surface of the pumice and ash and on the loose stones in the ravines of the mountain slopes; these were correctly regarded by Trenb as affording a satisfactory nutritive medium for the germination of the spores of cryptogams and the seeds of phanerogams. The important part played by algae, particularly the Cyanophyceae, in the colonisation of bare ground and poor soil has since been demonstrated in many other localities, and recently Fritsch ${ }^{2}$ has dealt fully with this subject also in the case of tropical regions, especially in Ceylon.

The Bacteria and Mould-Fungi may perhaps have played even a more important part in thespreparation of a favourable substratum. for the higher plants in the earliest phase of colonisation. Researches into the Bacterial flora were first undertaken during our (the third)

1 In Europe according to Boussingault there are $1-6$ milligrammes of nitric acid in a litre of rain-water; Von Ad. Mayer calculates that in a year the rain brings down about 1 kilogramme to each hectare [ $2 \cdot 47$ acres].

${ }^{2}$ Fritsch, F. E. "The rôle of Algal Growth in the Colonisation of new ground and in the determination of Scenery." The Geographical Journal, November 1907, pp. $531-548$. 
expedition ; it is, however, certain that these minute organisms were introduced on to the island and began to develope as soon as, possibly even before, the algae and spores.

Dr E. De Kruyff, Bacteriologist to the Agricultural Department of Buitenzorg, was kind enough to provide me with sterilised tubes and appliances for obtaining samples of earth, also a culture-plate for the enumeration of Mould-Fungi; he generously undertook the examination of our material. The bacteriological investigations based on four samples of soil (two samples from the Barringtonia and Casuarina forests, one sample from the strand-zone, one sample from the interior of the island) demonstrated the occurrence of between $1,300,000$ and $2,800,000$ (the average of four samples 2,200,000) bacteria in 1 gramme of soil, figures which agree with those obtained by De Kruyff from an examination of the soil at Buitenzorg in Java and with the results of similar calculations in regard to various soils in Switzerland.

The number of the bacteria species identified is not large, but it is important to notice that they belong to very different biological groups. Among the ordinary soil-bacteria, Bacillus mycoides and Bacillus Moiré (B. Megatherium De Bary?) were abundant, and Bacillus fluorescens liquaefaciens among typical putrefactive bacteria.

All four samples afforded examples of bacteria which destroy cellulose, pectin, and starch, as well as Urobacteria, the bacteria which decompose urea, a fact of some interest in view of the feeble development of animal-life on the island. Several Moulds were found on the culture-plate, but it is remarkable that no Yeasts occurred either on the plates or in the samples of earth. By far the most important fact from the point of view of the nutrition of vascular plants on Krakatau is the occurrence of such bacteria as play an important part in the circulation of nitrogen, the nitrite- and nitratebacteria and the nitrogen-fixing bacteria.

As the result of the disintegration of the nitrogenous substances of dead animals and plants by putrefactive bacteria and other microorganisms the nitrogenous compounds are largely converted into ammonia. A portion of the ammonia which is thus produced is fixed by the soil and afterwards converted by the action of nitrite- and nitrate-bacteria into nitrous and nitric acids which are readily taken up in the form of salts by the absorbing organs of vascular plants. Another portion of the ammonia is given off into the air as gas and some of it is given back to the soil by the rain in combination with nitric, nitrous and carbonic acids.

In the interior of the island also a considerable quantity of 
nitrogen is added to the soil in the form of ammonia, and this can be directly used by several of the green plants; for others it is made available as a source of nitrogen by the nitrifying action of nitriteand nitrate-bacteria.

Another means by which the soil of Krakatau, which originally contained no nitrogen, becomes richer in nitrogenous compounds is afforded by the action of nitrogen-fixing bacteria. The well-known free-living forms Clostridium Pusteuriunem and Azotobucter chroococcum, which possess the power of fixing atmospheric nitrogen, were not detected in the simples of soil, but by the employment of Beyerinck's method De Kruyff ${ }^{1}$ succeeded in isolating a new aerobic nitrogen-fixing bacterim, Bacterium Kralutaui, from soil taken from the small forests and from the Pes-caprae zone.

In addition to this free-living nitrogen-fixing bacterium, Bacterium radicicole has also been carried to the island by wind-agency; this species, which lives symbiotically in the roots of Leguminosae, is capable of fixing a considerable amount of atmospheric nitrogen. On the roots of all the Leguminons plants examined, Vigna, Cancevalia, Erythrine, I found the characteristic root-tubercles in abundance. As the result of their symbiosis with Bacterium radicicola, which by the assimilation of atmospheric nitrogen considerably reduces the intensity of the struggle for food on the substratum of pumice and ash insufficiently provided with nitrogenous and phosphorus-containing compounds, the Leguminosae have played an exceptionally important rôle in the colonisation of the island. This family is now represented by 16 species, belonging to 14 genera, partially in the Pes-caprae and Barringtonia formations in the strand-zone; in the inland flora also the Leguminosae are represented by Vigna, Cancovalia, Cacsalpinia, and Mucuma, and in both regions they exceed almost all other arborescent and shrubby plants in the number of individuals.

\section{v. The relative importance of the different agents of plant- dispersal in the colonisation of the Krakatau islands.}

Under the head of means of dispersal of fruits, seeds, and such vegetative organs as are specially adapted for reproduction, the same agencies were concerned in the colonisation of the Krakatan gronp, as in the colonisation of new islands in general; namely transport by birds, by wind, and by sea-currents.

${ }^{1}$ E. De Kruyff. "Sur une bactérie aérohe, fixant l'azote libre de l'atmosphère: Bacterium Krakataui." Bulletin du Dép. de l'agriculture aux Indes Néerlanduises, No. Iv. (Micro-Biologie I1.), Buitenzorg, 1906. 


\section{Ocean-eurrents.}

The seeds and fruits of strand-plants, such as occur everywhere in the drift-zone of the coasts, are transported, almost without exception, by sea-currents. In the ease of many of these their capacity for floating a considerable length of time in sea-water or in salt-solution without losing the power to germinate, has been demonstrated experimentally by Guppy ${ }^{1}$, Schimper, and others. Floating eapacity is not possessed in an equal degree by all strandplants. Some of them swim equally well whether freshly fallen from the tree or in a dry state, while others can be carried by water only after being dried. It is well known that such large drift-fruits as coconuts, the fruits of Cerbera Odollam, Nipa fruticans, Barringtonia, Calophyllhm, and Terminalia Catappa possess the power of floating for a considerable time. Similarly small fruits and seeds float for long periorls. In Guppy's experiments the seeds of Guettarda speciosa, Scaevola Koenigii, Morinda citrifolia, Toumefortia argentea and others among the strand-plants which oceur on Krakatau, germinated after floating on sea-water for 40 to 53 days. In Schimper's experiments seeds of Dodonaca viseosa germinated after floating in a $3 \frac{1}{2} \%$ solution of salt for 60 days, and Hibiscus seeds germinated after 121 days. Similar experiments have shown that other widely distributed strand-plants possess a much feebler floating eapacity. According to Schimper the seeds of Euphorbia Atoto float for 4 to 5 days only ; Pemplis acidula seeds, as Guppy demonstrated, sink at once when freshly fallen, and if left to dry for 14 days they float only for 2 to 5 days. The cones of Casuarina equisetifolia are said to float only for 1 to 2 days. While the short floating period of 2 to 5 days is clearly insufficient to admit of the transport of the seeds of the latter plant to islands situated a considerable distance from the mainland, it is long enough to account for its occurrence in Krakatan. The distance of the Krakatau islands from the coasts of Java and Sumatra and many islands in the Sunda Strait region is comparatively trifling. The island of Sebesi, which was only partially deprived of its vegetation by the eruption of 1883 , is only $19 \mathrm{~km}$. [12 miles] from Krakatau and only about $15 \mathrm{~km}$. [9 miles] from Verlaten and Lang islands. The distance of Krakatau from Sebockoe is only slightly greater. To the nearest points of the coast of Sumatra, Telong Kelapa and Varkenshoek, the distance is

1 Guppy, H. B., loc. cit. The Solomon Islands, London, 1887, p. 305. [The subject of seed-dispersal is exhaustively treated by H. B. Guppy in his more recent book, Observations of a Naturalist in the Pacific between 1896 and 1899, Vol. II. London, 1906.] 
37 and $40 \mathrm{~km}$. [23 and 25 miles]. To Java's Third Point the distance is approximately the same; and to the northern point of Prince island it is $43 \mathrm{~km}$. [27 miles].

Fruits and seeds of strand-plants may therefore be easily transported to the shores of the Krakatan islands by eurrents, which are not constant in direction, from all the neighbouring coasts of Java and Sumatra as well as from the islands in the Sunda Strait and in the Java Sea. The transport of floating plants and portions of plants by the current which sets to the sonth-west can be accomplished under farourable conditions in less than a day; more especially is this the ease from the norther'n entrance to the strait, from the Sumatran eoast at Varkenshoek, the Zutphen islands, from the island of Dwars in the channel, St Nicholas Point and Java's Fourth Point on the coast of Java. During the east monsoon the direction of this current remains constant for 18 hours; in the broarler and middle part of the strait, in the direction of Krakatan, its velocity is at least $3 \mathrm{~km}$. [18 miles] an hour and thus a transport for a distance of more than $50 \mathrm{~km}$. [31 miles] is possible between two tides. Seeds and fruits with feeble floating eapacity may thus be carried direct to Krakatau. It should be added that other possible means of transport such, for example, as Guppy has described in reference to the colonisation of the Cocos islands, are not exeluded.

Guppy has shown that small seeds of strand-plants such as Tournefortia argentea, Scaevola Koenigii, Pemphis acilula, etc. occur with sand in the crevices and cracks or in the holes and burrows made by molluscs and worms in stems and branches stranded on the beach. Seeds, like sand, are blown by the wind into every available cranny. The stems and branches are again floated off by high tides or storms and thus the seeds and fruits concealed in the erevices are transported to new localities without losing their power of germination.

By this method of seed-dispersal it is possible, therefore, for strand-plants, the seeds of which do not possess speeial floating capacity, to take part in the colonisation of new coast-regions: inland plants may be introduced by the same means.

There are also other methods by which germs may be transported across water.

Inundations and high tides on the coast and, in the interior, swollen rivers frequently earry freshly uprooted trees into the sea. The earth entangled in the mass of root above the surface of the water may contain various scellings and seeds, also Grasses and Cyperaceae ; epiphytes on the branches of the floating trees are out of reach of the injurions effects of sea-water. By the same means 
different kinds of animals may be carried across water. Semon ${ }^{1}$ attributes an important rôle to this means of distribution in the case of animals in the Malay Archipelago. The possibility of certain kinds of animals accomplishing a long sea voyage on floating wood has been demonstrated by the observations of Guppy, who states that in the course of a few years four living snakes were drifted to the Cocos islands on bamboo stems and tree trunks; he records one instance of the transport of a crocodile on a large tree stem to the beach of the islands.

Tree stems and branches played an important part in the colonisation of Krakatau by plants and animals. Large piles of floating trees, stems, branches and bamboos are met with everywhere on the beach above high-water mark and often carried a considerable distance inland. Some of the animals on the island, such as the fat Iguana (Varamus Salvator) which sums itself in the beds of streams, may have travelled on floating wood, possibly also the ancestors of the numerous ants, but certainly plants. On one of the trees stranded on the beach a long time ago I found the two tubular fungi Polystictus sanguineus and $P$. hydnoides. Their mycelia had apparently survived the sea voyage in the interior of the wood and had since produced a considerable number of fructifications, those of the blood-red $P$. sanguineus being met with a considerable distance away.

The blocks of pumice, which have been noticed since the great outburst on all coasts of the Sunda Strait and farther away on the beaches and covering the surface of the water in quiet bays, may, as Guppy states, serve for the transport of small fruits and seeds. Floating blocks of pumice and pieces lying on the beach may be swept by high tides as far as the strand-forest or to the sandy ground where the small fruits and sand collect in their numberless depressions and holes as in the crevices of floating wood. A succeeding tide carries back the pumice blocks with their freight of plants and they are drifted by currents to other coasts. The germination of Pemphis acidula, Scaevola Koenigii and Trinm fetta procumbens from seeds hidden in the cavities of pumice has often been observed on the Cocos islands. 'That this means of distribution must have played a more important part in the colonisation of Krakatau than in the Cocos islands, is shown by the great quantity of pumice which is not only piled up on all the neighbouring coasts but also covers large areas in the Sunda Strait and is frequently drifted back again to its place

1 Semon, R Im Australischen Busch und an den Küsten des Korallenmeeres, Edit. II., Leipzig, 1903, p. 349. 
of origin, the island of Krakatan, where it is strewn with other jetsam of the sea along the drift-zone (Pl. IV., fig. 3).

All these diflerent possibilities of transport over water, the comparatively short distance separating Krakatau from the coasts of Java, Sumatra, and other plant-covered islands, and especially the umusually favourable current-conditions have contributed to the result that the germs of a large number of plant species have been carried in a short time to the shores of Krakatan. The plants so introduced include species with seeds which are not adapted, or only in a slight degree, to dispersal by water. In addition to widely distributed strand-plants the Krakatan strand-flora includes also less well defined strand-species.

The number of species of the strand-region (67) appears small in comparison with the number included in the Indo-Malayan strand-flora (ca. 320). Several typical and widely-spread members of the Pes-caprae and Barringtonia formations are still unrepresented. We searched in vain, for example, among the Spinifex bushes for Tacco pinnatifida, with its beautiful foliage, which occurs in abundance on the istand of Edam. The handsome bushes of Crinum asiaticum, which decorate with their white flowers the Barringtonia forest, do not occur, nor the tall Calotropis gigantea which in other places is a common plant on sandy beaches. The latter is an Asclepiad with large violet flowers, and sceds covered with long, shiny and silky hairs which distinguish it as one of the few sea-shore plants adapted to wind-dispersal. Even more noteworthy is the absence on the beach of Krakatan of the whole Mangrove association which is so rich in speeies characterised by morphological and ecological peculiarities. The absence of these and other typical strand-plants is attributable to different causes. In some cases the species do not occur, or only in small numbers, on the stretches of coast which supplied most of the firuits drifted to Krakatau. Other's may have reached the beach but failed to find the requisite conditions on the pumiceous and ash-strewn ground. The fruits and seeds which we found most frequently in the drift-zone of Krakatau and Verlaten island are those mentioned in the lists given by Treub and Penzig; they are represented in the new strand-flora by many individuals, some of which have already reached the fruiting stage. Other plants drifted to the shore in considerable quantity produce a few seedlings, which, however, as is the case of Nipa fruticans and like the large seedlings of Rhisophora which are washed up on to the beach, fail to develope further. The absence of certain strand-plants like Nipa and the Mangrove plants, the seeds of which reach the island but do not survive, is due to the special conditions which prevail on the shore of the island. Another type of 
selection, the destruction by animals of certain seeds and fruits among the drift-material, especially by hermit and other crabs, as Schimper ${ }^{1}$ and $\mathrm{Guppy}^{2}$ have described in the case of other coasts, does not appear to have been operative in this instance. The small hermitcrabs which live in gasteropod shells, the busy peregrinations of which I have had an opportunity of noticing on the beach of Sumbawa and Noesa Kambangan, are not found on Krakatau or on Verlaten island. There appears to be no evidence of the occurrence of crabs such as Guppy has described as subsisting chiefly on the driftfruits and seeds on the beach of the Cocos islands, though the name "Crab Island" formerly applied to Krakatan suggests their former occurrence. Out of fifty to sixty living seedlings of different species of strand-plants met with in the drift in the Cocos islands only about a dozen species escaped destruction by crabs, with the result that, despite the richness of the drift-material, a strand-flora containing only a small number of species was produced. On Krakatan a number of plants have succeeded which belong to species the fruit, seeds and seedlings of which are most eagerly sought after by crabs: for example Cerbera Odollam, Calophyllum, Carapa, Cocos nucifera. The large number of coconut palms on Krakatan is an especially remarkable feature. Statements occur in the literature ${ }^{3}$ to the effect that coconuts from drift-material seldom germinate; moreover in many places empty nuts only occur' in the drift-zone. These nuts have not all been opened by crabs; the presence of a circular opening, from 1 to $2 \mathrm{~cm}$. in diameter, on many of them shows that the fruits were eaten by squirrels, which are common in the Archipelago, before their transport in the water.

\section{Seed-dispersal by birds.}

In addition to transport by water some of the strand-plants of Krakatan may have been introduced by birds. According to Guppy the seeds of Pemphis acidula adhere freely to the feathers of birds whieh build in the bushes of the coast regetation or obtain nesting material from them; in many instances the seeds of Krakatau plants may have been introduced in the bodies of birds.

The following plants included in the Krakatan list, Ximenic americana, Eugenia, Premna, Cassytha filiformis, are among those mentioned by Hemsley as having been found by Guppy and Moseley ${ }^{4}$ in an uninjured condition in the crops and intestines of fruit-eating birds. Schimper considers that Morinda citrifolia and Scaevola

\footnotetext{
1 Schimper, A. F. W. Indomalayische Strandflora, p. 75.

2 Guppy, H. B., loc. cit. p. 11.

3 Engler, A. Entwicklungsgesclichte der Pflanzentelt, II. p. 183.

4 Hemsley, W. B., loc. cit. Challenger Reports, Botany, Vol. I. pp. 43, 44.
} 
Kocnigii are possibly distributed in this way; further, the fleshy fruits of Clevodendron inerme, Vitex Negundo, and Vitis trifolice serve as food for fruit-eating birds which frequent beaches and forests. In the case, therefore, of nine of the strand-plants the fruit is adapted for dispersal in the bodies of birds. Bearing in mind the fact, as stated by Guppy and Beccar ${ }^{1}$, that fruit-eating birds are often not over-critical in their choice of food, and do not feed exchusively on fleshy fruits, and that the large size of seeds is not a fatal obstacle to their being swallowed, it is probable that a still greater number may be distributed endozoically. The inlabitants of the Cocos islands often find the large spherical seeds of Caesalpinia Bonducella, a Leguminous member of the Krakatan strand-flora, in the stomachs of frigate-birds. Seeds of considerable size (e.g. Muscat nuts) are often met with in the crops and stomachs of fruit-eating doves, and Beccari records the discovery of the seeds of a palm, Orania armensis, $6 \mathrm{~cm}$. in diameter, in the stomach of a Cassiowary.

The importance of the dispersal of secds in the crops and stomachs of birds over long distances has often been called in question in view of the very short interval, in the case of many birds, between eating and ejecting their food. Kerner ${ }^{2}$ found in thr'ushes' dung numerous seeds of Ribes three-quarter's of an hour after the berries were eaten. Seeds of Elder (Sambucus) are known to have been ejected after an interval of half an hour. The interval in the case of most birds is $1 \frac{1}{2}$ to 3 hours. In spite of the short period of digestion which characterises fruit-eating doves their co-operation in the colonisation of Krakatau is by no means impossible; many birds fly with a velocity of 50 kilometres an hour [31 miles], while dores may cover 80 or more kilometres [50 miles] in an hour. It is therefore not impossible that birds which have eaten fruit on the coastal regions of the Sunda Strait may excrete digested but uninjured seeds on Krakatan after less than an hour's flight.

Among the plants in the interior of the island there are undoubtedly several which have reached the island by the agency of birds. The seeds of varions species of Ficus in particular owe their introduction to transport in the stomachs or crops of birds.

Schimper considers that the fig-trees which are abundant in the inland regions of the Malay Archipelago owe their distribution to this agency, and Guppy attributes the fact that fig-trees constitute with Casuarina the commonest and most important trees in the interior of the small coral islands of the Solomon Archipelago to the

1 Beccari, O. Malesia, Vol. I. p. 1.

${ }^{2}$ Kerner, A. Pflanzenleben, Ir.p. 800. [The Natural History of Plants: English translation, edited by Prof. F. W. Oliver, Vol. II. p. 864.] 
dispersal of their seeds by fruit-eating doves. Penzigi has demonstrated the introduction of Melastoma polyanthum by bird-agency. Among the latest arrivals on the island there is no doubt that Trema amboinensis, one of the Celtidoideae with small juicy finits, must be included in the list of plants introduced by animal-agency. Carica Papaya, which occurs on Verlaten island, in addition to its dispersal by birds may also be earried by flying foxes (Pteropus) which, according to statements by Forbes (loc. cit. p. 3t), are eapable of extended flight over water. As already pointed out, the fact that Verlaten island was inhabited for a short time some years ago render's it possible that this favourite plant in cultivation was introduced by man.

\section{Dispersal of finits and seeds by wind.}

The third method of dispersal of fruits and seeds, by wind, is of exceptional importance as a factor in the development of the new flora of Krakatau. This was demonstrated in a remarkable way during Treub's first visit to the island. Previous to the publication of the results of the first Krakatau expedition of 1886, opinions in regard to the part played by wind in the colonisation of new land, especially in the case of distant islands, were divided ${ }^{2}$. The view was widely held that the dissemination of spores and seeds by air-currents was only of local importance, and only assumed a geographical significance after frequent repetitions in the course of generations. This opinion was based on many observations on the colonisation of freshly exposed surfaces on the mainland where ground had been either partially or completely deprived of vegetation and afterwards eolonised from neighbouring districts. Patehes of new ground may be formed by earthquakes, floods, the accumulation of detritus-cones, piles of boulders, glacial moraines in the mountains, sandbanks in river-beds and at the mouth of rivers and by the formation of lava- and ash-fields in volcanoes. Seeing that the action of wind as a factor in the dispersal of vascular plants ${ }^{3}$ falls behind other agents of distribution when the newly exposed land is com-

1 Penzig, O., loc. cit. p. 111.

2 Vide Schimper, A. F. W. Pflanzengeographie, 1898, p. 90. [Plant Geography, p. 80.]

3 In the Alps, where disturbances in the surface of the ground occur much more frequently than in the plains, the anemochoric species (that is, those which owe their seed-dispersal to wind) predominate; Vogler ["Über die Verbreitungsmittel der sehweizerischen Alpenpflanzen," Flora, Bd. 89, 1901, p. 73 (Reprint)] has supplied a particularly good example of this, supported by statistics, in his account of the spread of vegetation over the ground which was left bare by the shrinkage of the Rhone glacier. 
paratively near to plant-covered areas, at least in flat regions, it is intelligible that the possibility of wind-transport over great distances should be doubted, as, for example, the transport of seeds and spores to distant islands, or, at most, admitted only in the case of spores.

The fact that a large proportion of the regetation of volcanic islands, situated a considerable distance from continents, consists chiefly of ferns, and the occurrence on coral islands of ferns and certain species of flowering plants which could not well be introduced except by wind, aftord evidence of the far-reaching influence of air-currents. There are, indeed, several observers who acknowledge the importance of wind-action as a factor in the colonisation of such districts. Engler ${ }^{1}$, in his work on island floras and the floras of tropical moumtains, has laid stress on the view that light seeds are carried over wide areas in the higher currents of the atmosphere during periodically recurring strong winds. In his comparative treatment of the floras of the larger islands in the Pacific Ocean, especially of the Sandwich islands, he arrives at the conclusion, based on his study of the means of dispersal of fruits and seeds, that of the 675 species in the Sandwich islands 140 spore-bearing plants and 14 seed-plants owe their distribution to wind ; in the case of 322 species dispersal by birds is possible ( 56 species by coast-birds; 241 in the intestines of birds, and 26 on their feathers). The fact that of the 669 indigenous species in the Sand wich islands not less than $500(74.6 \%)$ are endemic, demonstrates the exceptional dispersal of seeds by wind and by birds over such long distances as are in question as regards these islands. Before Treub called attention to the important rôle of wind in the dissemination of plants, Beccari ${ }^{2}$ had arrived at the conclusion, as the result of his observations in the Malay Archipelago, that a considerable number of species are confined to mountain-summits separated from one another by as much as 3200 kilometres [2000 miles], and further that nearly related species are separated from one another by long distances.

According to Beccari the mountain-tops of the Nalay Archipelago occupy a position where, during part of the year, particularly from November to April at the time of the west monsoon, the strength and constant direction of the wind are maintained for a longer time than in the lower regions and on the sea-coasts. It is therefore clearly

1 Engler, A. Versuch einer Entuicklungsgeschichte der Pfanzenvelt, Ir. Teil. Die extratropischen Gebiete der Südlichen Hemisphäre und die tropischen Gebiete, Leipzig, 1882.

${ }^{2}$ Beccari, O. Malesia, Vol. I. Fasc. iii., 1878, pp. 214-235.

Beccari, O. "Beiträge zur Pflanzengeographie des Malayischen Archipels" (abstract by A. Engler). Bot. Jahbü̈cher, I. Bd., 1881. 
possible that the north-west monsoon may carry dust and small dustlike seeds from the western part of the Archipelago to the peaks of the eastern islands. In this connexion Beccari calls attention to the long distances which volcanic ashes (eruption of Tamboro at Sumbawa in 1815) may be carried by currents in the upper regions of the atmosphere; he also gives figures indicating the lightmess of such seeds as he considers may be distributed by wind. A seed of Nepenthes phyllamphora weighs 0.000035 grammes, seeds of Rhododendron verticillatum and Dendrobium attenuatum $0.000028 \mathrm{gr}$. and $0.00000565 \mathrm{gr}$. respectively. As the north-west monsoon in the Malay Archipelago has a high intensity it is easy to understand why Rhododendron, Nepenthes, and other plants peculiar to the mountains of the western region and to the mountains of Java occur on the mountain-summits of the Moluceas and New Guinea, and why, for example, several Alpine Indian plants are met with on the Pangerango (Gentiana quadrifaria Bl., Ramunculus javanicus Reinw., Rammculus diffusus D.C., Valeriana javanica Bl., Primula imperialis Jungh., Gnaphalium javanicum Reinw., ete.). Beccari considers that these have been carried by the north-west monsoon, to some extent also by birds, from regions further west, first from Sumatra, and thither from the mountains of India. He attributes very great importance to the north-west monsoon, which is especially prevalent from November to April, as a factor in the transport of seeds, more particularly from the west part of the Archipelago to the eastern islands.

The observations of Junghuhn ${ }^{1}$ on the conditions of the monsoon wind in Java are not consistent with this conclusion. The west or north-west monsoon, which produces cloudy weather in Java from December to February, extends, according to Junghuhn, only a short distance above sea-level, at most up to 1600 metres [5250 ft.] on the slopes of the mountains; while, on the other hand, the south-east monsoon blows the whole year round in all parts of the atmosphere at an altitude above 2000 metres $[6600 \mathrm{ft}$.$] . During the period of$ twelve years during which he observed the direction in which the steam-clonds of the volcano are drawn ont as stripes in the atmosphere reaching miles in length, he found that this is always towards the west, W.N.W., sometimes W.S.W. and never towards the east, not even when, in the months of January and February, a strong westerly or W.N.W. wind brings the heaviest rain-showers over the low alluvial flats. His remarks in another passage (loc. cit. p. 408) diminish, to some extent, the force of these conclusions: he writes,

1 Junghuhn, F. Java, seine Gestalt, Pflanzendecke und innere Bauart, Leipzig, 1852, Bd. I. p. 165 . 
"The south monsoon wind blows steadily at these altitudes (7500$10,000 \mathrm{ft}$.) the whole year, but as a rule it decreases in force at night or entirely drops. It frequently shifts from its normal direction to east-south-east, east and east-north-east and in the course of the day it increases spasmorlically in intensity. During the rain-monsoon it is replaced by a north-west wind which blows at this season in the valleys, and this occurs the more rarely the higher the peak on which the observations are made. On mountains of $10,000 \mathrm{ft}$. and higher I have never noticed a west wind, but at a height of $9000-9500 \mathrm{ft}$. this was occasionally observed. The north-west wind then ascends the slopes on the opposite side of the conical mountain, covering everything with a dense cloud, and blows over the peak. But on these higher peaks it rarely retains the ascendancy which it has wrested from the east monsoon for more than half a day or at most a whole day...then the latter reasserts itself and an interval of several weeks or months elapses before the west wind succeeds in rising to so high a level." As my own excursions on the volcanic mountains of Java were made at the time of the west monsoon, November to March, I was able to convince myself of the correctness of Junghuhn's conchisions. The south-east wind prevailed everywhere (Gedeh mountains, Dieng and Tengger mountains in Java, Merapi and Singalang), though I once had an opportunity of observing on the old crater of Aloen-Aloen of the Gedeh mountains a strong west mronsoon wind accompanied by mist and cloud. Verbeek also states (Kraliatau, II. Teil, p. 149) that in Java the wind in the upper currents of the atmosphere blows constantly from the east (S.E., E. and more rarely N.E.) and this is the case when either an east or west wind is blowing in the lower strata of the air. He estimates the lowest limit of this high wind at 2000 metres [6600 ft.]. He is also of opinion that its velocity increases with the height and, on the data furnished by the distances to which ashes were carried during the Krakatau eruption, he estimates the velocity at an altitude of 50 kilometres [31 miles] at 121 kilometres $\left[75 \frac{1}{2}\right.$ miles $]$ per hour. In other regions also, as, for example, in the Swiss Alps, Vogler ${ }^{1}$ has demonstrated the possibility of wind-transport over long distances.

From the results of numerous calculations as to the transport of leaves, etc., on glaciers and snow-fields in relation to the determination of the nearest normal station of the plants, Vogler arrives at the conclusion that during storms seeds may be carried in the Alps to a distance of 20 kilometres [121 miles]. As evidence of the probability of transport to a still greater distance, even in the case of fairly large seeds and fruits, he quotes the remarkable hail of salt on

1 Vogler, P. "Über die Verbreitungsmittel der schweizerischen Alpenpflanzen." Flora, Bd. 89, 1901. 
the St Gotthard which occurred on August 30th, 1870, when crystals of salt fell, weighing in some cases $0 \cdot 76$ grammes; these had been brought by air-currents from North Africa or from the nearest points on the sea-coast, a distance of at least 250 kilometres [156 miles].

The stone-rain of February 20th, 1907, at Trélex sur Nyon, which Rollier ${ }^{1}$ has described, is a more recent example of the same phenomenon. White quartzose pebbles as large as peas and hazel-nuts were carried by air-currents from some region rich in siliceous rocks, presumably from the south of France or Spain, that is for a distance of more than $100 \mathrm{~km}$. [62 miles].

The best proof of the transport of plant-germs over large distances is afforded by the observations on the colonisation of Krakatau. In this case we have definite proof of long-rlistance dispersal: Sebesi, the nearest island with plants, is $18.5 \mathrm{~km}$. [11 $\frac{1}{2}$ miles] distant, and the nearest points of Java and Sumatra are situated $40 \cdot 8$

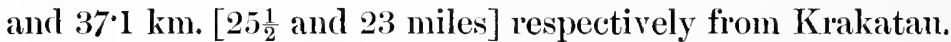

The results of 'Treub's investigation of the island in the year 1886 have already been described (pp. 6, 7 ). The first colonisation of the volcanic cone, and of the interior generally, was effected by entirely different means from that of the shore-region, and almost exclusively by the introduction of plant-germs by wind-agency. Cells of bluegreen Algae, Bacteria, Diatoms, the spores of Liverworts, Mosses, and Ferns, and the seeds of at least six of the eight phanerogams which Treub found in the interior of the island were carried by aircurrents. The first phase of colonisation was characterised by the predominance of Ferms, which were represented by 11 species widely distributed in the Indo-Malayan region. Since then there has been a considerable increase in the number of wind-borne species including, in addition to Ferns, members of the Gramineae, Cyperaceae, and Orchidaceae.

Penzig estimates that the following seventeen species $(32 \%$ of the total flora), recorded from Krakatan up to the year 1897, were introduced by the agency of wind: all the Composites (eight species: Wedelia asperrima, Wedelia scabriuscula, Blumea balsamifera, Blumea hieracifolia, Pluchea indica, Vernomia cinerea, Emilia sonchifolia, Wollastonia sp.), five species of Gramineae (Gymnothrix elegans, Phragmites Roxburghii, Imperata arumdinacea, Saccharum spontancum, Pogonatherum crinitum), and the four Orchids (Spathoglottis plicata, Vanda Sulingi, Arundina speciosa and

${ }^{1}$ Rollier, L. "Une pluie de pierres survenue à Trélex (Vaud) le 20 férrier, 1907." Archives des sciences physiques et naturelles, Oct. et Nov. 1907. (Comptes rendus des tracaux présentés à la 90 session de la Société helvétique des sciences naturelles à Fribourg, 1907, p. 73.) 
Phajus sp.). He inchudes the Cyperaceae (Cyperus digitate, Fimbristylis spathacea, Lipocarpha foliosa) and the two Grasses, Spinifex squerrosus and Ischacmum muticum in the group of "roophilous species," that is, species distributed by water. In April 1906 the floras of the three islands included twelve Composites (Comysa angustifolia, Conyza indica, Erechthites hieracifolia, Wedelia glabrata, Senecio sp. ${ }^{1}$ introduced since 1897); six Gramineae (excluding Ischeomum and Spinifex; Pennisetum elegans added since 1897); four Cyperaceae (Mariscus umbellatus, a new arrival since 1897) and five Orchids (Cymbidinm Finlaysoniconum since 1897). In the case of all these 28 species $(30 \%$ of the phanerogam flora) wind-agency has probably been the means of transport; in some instances other means of dispersal are also possible and were perhaps concerned in the colonisation of Krakatau. Of these 28 presumably wind-borne species, some are found also in the strand regetation of Krakatau and occur on the coasts of Java and Sumatra as often as in the interior. The possibility of transport of the fruits by water is by no means excluded, at least as regards such members of the flora as Conyza indica, the species of Blumea, Wedelia and Wollastonia which are especially common on the beach and are reckoned by Schimper among the typical strand-plants. In the flora of the island of Edam, and at localities on the coasts of Java and Sumatra which we visited, Composites were not uncommon; on Edan we found six (two of which occur also on Krakatau, Vernonia cinerea and Wedelia glabrata); at Vlakke Hoek, the ubiquitous strand-plant Wedelia glabrata; at Java's First Point four (three of which, Blomea balsamifera, Wedelia glabrata and Vernonic cinerea occur also on Krakatau). Some of the Grasses included in the list occur not only in the coast-flora of Krakatan, but are also common in that of Java, Sumatra and elsewhere: Imperate arundinacea, for example, is mentioned by Hemsley as a strand-plant which owes its distribution to sea-currents. On the other hand he expresses doubt as to the efficacy of this means of dispersal in the case of Composites, while Schimper lays stress on the fact that the small fruits of most of the strand Composites and those of the species Wedelia biflor a, with the widest oceanic distribution, are not provided with a pappus and are therefore ill-adapted for dispersal by wind. We cannot go far wrong if, without accepting his argument against wind-dispersal as convincing, we follow Schimper in admitting that some of the Composites of the strand-flora may have been carried by sea-currents.

${ }^{1}$ Senecio sp., presumably also Conyza indicu, Conyza angustifolia, the species which were found by Treub in 1856. (T'reub, loc. cit. p. 218, "deux espèces de Conyza.") 
In the dispersal of seeds and fruits by wind over long distances, structural adaptations to flight are of less importance than reduction in weight. The greater the velocity of the wind the more efficient it is as an agent of seed transport. Seeds which are unaffected by the wind in the Swiss plains, or are carried for short distances only, in higher regions, as Vogler has shown, are blown much farther. The upper limit of weight of "light seeds" capable of flight is higher in the mountains where the winds are stronger than in the valleys where lighter winds prevail. Vogler considers that in the case of winds having a velocity of 30 metres [98 ft.] a second, a special apparatus for flight is umnecessary. Winds reaching this velocity are not infrequent during storms in the Indo-Malayan region. In the Sunda Strait district it is possible, therefore, that light seeds and fruits which possess no special flight-apparatus may be dispersed by wind. Observations in Krakatau demonstrate that for dispersal over wide areas seeds with special structural adaptations (pappus-structures of the Compositae, hair-like flight-organs in the Gramineae, seeds with a membranous border as in the Orchidaceae) have an advantage. Very light seeds specially adapted to wind-dispersal, such as those of Orchids, the spores of Ferns and other cryptogams, are carried by the ordinary monsoon wind, while the introduction of larger and heavier seeds, some of which have no special flight-organs, is the result of more violent storms and cyclones.

\section{The part played by the several agents of dispersal in the development of the present flora of Kraliatau.}

It is clear from the above enquiry into the significance of the various means of dispersal of plant-germs in the colonisation of the Krakatan islands, that the classification of the plants so far discovered according to their methods of distribution is by no means easy and camnot in any sense be carried out within sharply defined limits. As regards the five Orchids, which most probably owe their introduction to air-currents, other means of dispersal (as, for example, in crevices in tree stems) camnot be entirely excluded, and this applies to other presumably wind-borne plants, the seeds, or such vegetative parts of which as are capable of reprodncing the species, may have been carried in the roots or tangle of branches of floating wood. Grasses and Cyperaceae, which are often found on the beach and in swampy places, may have been introduced on the feet or feathers of swimming and marsh birds. In the case of the strand-plants also, as already stated, in addition to the characteristic method of distribution of the fruits and seeds by currents, which has in several instances been demonstrated as the means of dispersal, there are possibilities of 
introduction on floating wood, on pieces of drifted pumice carrying sand and seed, while some of the plants may have been introduced by birds. Of the total number of phanerogams found on the group of islands up to $1906,36(39 \%)$ have certainly been brought by oceancurrents. If we include such Krakatau strand-plants as belong to genera with well-known halophytic species and such typical strandplants as may possibly have been distributed by birds, together with strand species of Compositae, Grasses and Cyperaceac, which may have been introduced by sea-currents as well as by wind and birds, the number of plants included in this group is brought up to 67 , or $72 \%$ of the total.

The number of plants brought to the islands by birds cannot be exactly estimated. It is almost certain that the nine inland species $(10 \%$ of the total) mentioned on page 58 and possibly nine species in the list of strand-plants were introduced by this means, that is 18 species in all or $19 \%$ of the whole flora; this estimate does not take account of the possible part played by marsh and water birds in the dispersal of Grasses and Cyperaceae.

The data in regard to the number of wind-distributed species are equally doubtful. If we include only the Orchidaceae, the Gramineae, with the exception of Spinifex and Ischaemum, also Mariscus umbellatus among the Cyperaceae, and excluding all the Composites which occur on the strand, the number amounts to 15 species or $16 \%$; including all the Composites and the four Cyperaceac, 28 species or $30 \%$ of the total.

The facts given in the list of the Krakatan flora in regard to the distribution of individual plants show that they are almost without exception species which are ubiquitous in the tropical zone or at all events in the Malay Archipelago. Any attempt to explain the occurrence of the few species which are not widely distributed, by reference to the prevailing currents and winds from Java, Sumatra, and the other islands of the Archipelago, must for the present at least prove futile. This is due to the fact that the floras of the different localities in Java and Sumatra with which we are concerned and of the other islands in the Java Sea and Sunda Strait are too little known.

Of the total number of phanerogams, according to the method of reckoning adopted, $39-72 \%$ have been introduced by sea-currents, $10-19 \%$ by birds, and $16-30 \%$ by air-currents. In order to appreciate correctly the importance of the dispersal of germs by windagency it is necessary to bear in mind that the Ferns, of which there are 16 species, also the lower cryptogams, almost without exception (see Polystictus, p. 56) were introduced by this means. Wind- 
borne species constitute $37 \%$ ( 25 phanerogamous plants, 16 ferns) of the vascular plants. The large number of Ferns and other cryptogams is obviously explained by the fact that the prevailing winds in this region serve for the dispersal of germs over a distance of approximately 30 kilometres [181 miles], while as regards more distant islands the transport of even the lightest germs is effected ouly by unusually high winds and is therefore of comparatively rare occurrence. This is in accordance with the remarkable fact that in the Cocos islands, which have several phanerogams in common with Krakatau, Ferns are entirely absent and only three cryptogams, a moss (Hypmum fuscens, Hook. and Arn.), a fungus (Polyporus luridus, Fries), and a lichen are recorded by the three naturalists-Darwin, Forbes, and Guppy-who have visited the islands.

\section{The succession of plant-associations and the future character of the vegetation of Krakatau.}

The comparatively advanced state of differentiation of the vegetation into plant-associations or formations is no less surprising than the remarkably large number and the variety of species in the new flora of Krakatau. As Penzig showed, the development of plantassociations had already begun in 1897. On the beach the plants of the Pes-caprae formation predominated. In the interior of the island the vegetation presented the appearance of a grass-steppe. Ferns constituted the dominant plants on the slopes of the cone. Since 1897 the aspect of the vegetation has undergone considerable change; the strand-flora is divided into two formations. An outer zone of varying breadth, reaching in places to the tide-level, consists of low creeping grasses and herbaceous plants, bushes and shrubs; the typical Pes-caprae formation. Behind this rises the strandforest (Barringtonia formation), the composition of which is not yet equal in variety of species and in gloomy grandeur to the Barringtonia strand-forests on the coasts of Java and Sumatra, nor will it soon reach the same level. Neither of these strandformations is as yet closed. Grasses, Cyperaceae, Ferns and Composites spread from the grass-steppe of the interior through clearings in the forest to the lower carpet of Ipomaea and Spinifex, while in other directions groups of strand-plants have penetrated inland for a distance of 300-500 metres. The beautiful group of coconut palms, 400 metres from the shore-line, represented in the photograph (Pl. VI., fig. 7, p. 30), affords an example of the latter. Groups of older plants of Barringtonia, Calophyllum, and Casuarina occur at various distances from the shore, while others, young coconut palms and Pandanus clumps, are so near the edge of the sea that their 
stems are washed by the waves at high tide. The strand regetation on the south-west corner of Krakatan, where it is most widely spread, is composed of elements of different ages, the oldest of which occur for the most part towards the interior, the youngest nearer to the tidal zone (see, for example, Pl. V., fig. 5). This distribution of the recent littoral flora over a relatively broad zone is most readily explained by the gradual growth of the island in the shore-region, a gradual seaward extension of the shore-line in the course of years.

Measurements taken by Verbeek proved that even during the first few months after the eruption there were considerable alterations in the sea-floor all round the Krakatan islands. Some of the pumice and masses of ashes were carried hither and thither by high seas: some sandbanks which were formed shortly after the outburst completely disappeared, while in other places the light and easily moved material was piled up into new submarine hills and banks or depositerl on the shores of the three islands. In this way the flat sandy shore has received important additions on the south and west coasts of Krakatau and on the south coast of Verlaten island. These accumulations of material on the beach remain, though reduced in size. It is obvious that the oldest strand-plants, which sprang from the seeds and fruits from the drift formed in the first year, have been gradually separated from the beach by a constantly increasing belt and that during this shifting of the shore-line new plant-germs were introduced with the pumice and took part in the formation of the present discontinuons strand-forest. Other factors may of course have been concerned in the building up of this forest, such as are responsible for the spreading of the strand-plants above the normal drift-zone in coral islands or other coast-lines, but these factors afford a less probable explanation than that already suggested. It is, for example, hardly conceivable, considering the present state of the fauna of Krakatau, that fruits and seeds were carried inland from the drift-zone by animal-agency. It has, however, elsewhere been shown that crocodiles, lizards, and turtles, that is, animals of which some already occur on the island, are of importance from the point of view of plant-dispersal. Beccari states that he found a large quantity of Pamlanus fruits in the stomach of Lophure amboinensis, and that in Borneo certain turtles constantly eat the fruits of a Durio and deposit the seeds with their exerement. On the other hand the agency of crabs, by which, according to Guppy, the germs of certain plants, especially those of Morinda citrifolia, Hernandia peltata, and Cordia subcorclata, have been spread over the interior of the Cocos islands, may be disregarded, as the seeds and fruits (Cocos, Burringtonic, Culoplyyllum, P(ondanus) which have been carried farther inland are those which 
crabs most eagerly search for and which can least withstand their attacks.

The level ground behind the strand-forest, gently sloping towards the foot of the cone, as well as the lowest ridges and valleys of the mountain, are still occupied as they were ten year's ago chiefly by Grasses, Cyperaceae and Compositae, while the Ferns have already come to ocenpy a subordinate place. Two representatives of the phanerogams of the shore (Scaevola Koenigii and Toumefortia argentea) were found by Treub in the interior. Since then the trees and shrubs have increased in number in the steppe or desert-like regions. These have advanced either singly or in groups on to the flat ground beyond the strand-forest and, as we have already described, they have formed forest-like patches in the ravines of the cone.

If the further development of the present Krakatan vegetation is not interrupted by a fresh volcanic ontburst, the island, with the exception of the steep rock-face, may be completely clothed with vegetation in the course of the next fifty or sixty years.

The voleano of Tamboro in the island of Sumbawa has become covered afresh with a dense forest within a similar period. In the shore-zone the extension of the forest-formation will lead to the disappearance of clearings which are oecupied by herbaceous plants and bushes. During the derelopment of a closed Barringtonia formation, some of the present members of this association will in the future have a difficult task in competing with the growth of new species. The building up and completion of the formation will, as elsewhere, be accompanied by a reduction in the number of species. Less well equipped forms will disappear or will be driven towards the shore, where they will mix with plants of the Pes-caprae formation and in some places onst them from their position. Low or slow-growing trees and shrubs which can no longer flourish in the high Barringtonia forest may spread inland almost unhindered. Those plants which have hitherto been facultative strand species, possessing seeds or fruits which, though not definitely wind-borne, may be carried inland by wind for short distances, will rapidly spread towards the interior; similarly other plants, as, for example, the different species of Fieus, the fruits of which are readily eaten by birds, will spread in the same direction. It is possible that the forest in the principal gorge of the mountain is at present composed of these elements of the coast-flora; perhaps future visitors to the island may find there many other plants, the germs of which have been introduced by birds, but more especially by wind, from the neighbouring islands and not from the littoral zone of Krakatau. We may indeed expect that plants will eventually be found in the 
higher localities which have not, like those which we collected, come from the strand regetation and from the low-lying parts of adjacent islands but from the higher regions of the Javan and Sumatran mountains; plants with light seeds which have been carried from the high volcanic cones of Java by strong winds which blow at the higher altitudes, especially by the south-east winds which prevail during the greater part of the year. Above all we may expect to find in the future those wind-distributed and animal-distributed species which in Java and Sumatra take possession of patches of ground in which volcanic eruptions have destroyed all traces of regetation. In such situations, as Schimper ${ }^{1}$ has shown in the case of Goenong Goentoer and as I propose to describe ${ }^{2}$ in a further account of the colonisation of volcanic areas in Java and Sumatra (Gedeh, Pangerango, Papandajan, G. Goentoer, Dieng and Tengger mountains in Java, Merapi and Singalang in Sumatra), are found Grasses, Cyperaceae, Ferns, and Orchids, also shrubby and arborescent phanerogams with wind-distributed seeds and fruits, especially species of Rhododendron and Guaphatium, while other plants, Vaccinirm, Gaulteria, Myrica, Aralia, etc., are distributed chiefly by birds. Many of the latter plants which live in the forests as epiphytes, assume the habit of ground-plants on a volcanic substratum where there is little competition with other plants, and at a later stage, when the vegetation becomes denser and arborescent plants occupy the ground, they revert to an epiphytic manner of life.

In the mountain forests, which extend both upwards and downwards, new conditions of life are produced. Spores of cryptogams and seeds of phanerogamous plants, which have not as yet met with conditions necessary for germination and growth, at a later stage form new elements in the flora. Lianes, epiphytic mosses, ferns and orchids make their appearance. The rocks on the mountain slopes become clothed with liverworts and mosses in shady places, and lichens spring up in more sunny situations. The mycelia of monld-fungi and species of the Phalloideac and Agaricineae flourish in the decaying leaves on the ground of the forest. Possibly the bleached saprophytic flowering plants and parasites may also obtain a footing on branches and roots.

Man plays no part either in opposing or accelerating this derelopmental process. The west regions of Java, and the whole of the sonthern regions of Sumatra are still sparsely populated; many fertile

${ }^{1}$ Schimper, A. F. W. Pflanzengengraphie, p. 201. [Plient Geography, p. 185.]

2 Ernst, A. "Die Besiedelung vulkanischen Bodens auf Java und Sumatia." To be published in Vegetationsbilder, by G. Karsten and H. Schenck, Jena, 1908. 7 Reihe, Heft 1 and 2. 
areas are everywhere ready to hand to industrious settlers and Krakatau will long remain, as it was before the eruption, uninhabited and will be visited only for a short time by a few fishermen or by explorers. A fresh growth will continue to spread from the shore and from the slopes of the mountain, the grass steppes of the intermediate zone will grow less and less and finally disappear. At last after a long interval the regetation on the desolated island will again acquire that wealth of variety and luxuriance which we see in the fullest development which Nature has reached in the primaeval forest of the tropics.

\section{ADDENDUM I}

(Footnote, 1. 29.)

Lotsy states in his Vorlesungen äber Deszendenztheorien, Pt. ii. p. 479 (G. Fischer, Jena, 1908), that an old Cycas found by Dr Valeton on the island a few years ago is supposer to be the only remnant of the original regetation. As the results obtained during the expedition of 1905 , in which Dr Valeton took part, have not been published it is impossible to say whether the "Old Cycas" is identical with the specimen which we found on the beach of the south-east coast of Krakatau. Although our plant had reached a considerable size relative to the short existence of the new flora, it certainly does not belong to the original regetation of the island: it occurs on that part of the littoral zone which was formed as a result of the eruption of 1883

\section{ADDENDUM II}

(Footnote, p. 34.)

While the English translation was in the press, Mr Verbeek informed me in a letter that on a third visit to the island of Krakatau, he succeeded in taking a good photograph of the middle part of the steep rock-face. A print, with a short explanatory note, was afterwarls forwarded by the government of the Dutch East Indies to those libraries which had officially received a copy of his work on Krakatau. The copy at my disposal did not contain this photograph: hence the above statement. I take this opportunity of thanking $\mathrm{Mr}$ Verbeek for information which he kindly supplied at my request on this and other points. 


\section{BIBLIOGRAPHY}

Backer, C. A. Flora van Batavia. Deel r. Dicotyledones Dialypetalae. Batavia, 1907.

Beccari, 0. Malesia. Vol. I. Fasc. mr. 1878.

_ Beiträge zur Pflanzengeographie des malayischen Archipels (communicated in abstract by A. Engler). Botan. Jahrbücher. I. Bd. 1881.

Blume, C. L. Bijdragen tot de Flora van Nederlandsch Indie. Batavia, 1825.

- Enumeratio Plantarum Javae et Insularum adjacentiun. Haag, 1830.

Flora Javae, 1829.

Boerlage, J. G. Handleiding tot de Flora van Nederlandsch Indie r.--III. Leiden, $1890-1900$.

Boguslawski, G. v., and 0. Krümmel. Handbuch der Ozeanographie. I. Bd. 1884. II. Bd. 1898.

Campbell, D. H. On the distrikution of the Hepaticae and its significance. New Phytologist. Vol. vr. 1907, p. 203.

Christ, H. Die Farnkräuter der Erde. Jena, 1897.

Engler, A. Versuch einer Entwicklungsgeschichte der Pflanzenwelt. Ir. Teil. Die extratropischen Gebiete der südlichen Hemisphäre und die tropischen Gebiete. Leipzig, 1882.

—_ Über die neueren Fortschritte der Pflanzengeographie (from 1899). Syllabus der Pffanzenfamilien. rv. Edit. Berlin, 1904.

Engler, A., and K. Pranti. Natürliche Pflanzenfamilien. I. Teil, 4 Abteilg. bis Iv. Teil, 5 Abteilg.

Ernst, A. Die Besiedelung vulkanischen Bodens auf Java und Sumatra. "Vegetationsbilder" published by G. Karsten und H. Schenck. Jena. G. Fischer, 7 Reihe, 1908.

Forbes, H. O. Wanderungen eines Naturforschers im Malayischen Archipel ron 1878-1883. I. Bd. Jena, 1886. [A Naturalist's Wanderings in the Eastern Archipelago, 1878-1883. London, 1885.]

Fritsch, F. E. The rôle of algal growth in the colonization of new ground and in the determination of scenery. The Geographical Journal. November, 1907, pp. $531-548$.

Goebel, K. Pflanzenbiologische Schilderungen. Bd. 1. Marburg, 1889.

Guppy, H. B. The dispersal of plants, as illustrated by the Flora of the Keeling or Cocos Islands. Reprint, 1890.

- The Solomon-Islands. London, 1887.

- [Observations of a Naturalist in the Pacific between 1896 and 1899. Vol. II. Plant-dispersal. London, 1906.]

Hann, J. Handbuch der Klimatologie. II. Bd. Stuttgart, 1897. Lehrbuch der Meteorologie. Leipzig, 1901.

Hemsley, W. B. Report on Present state of Knowledge of varions Insular Floras, being an Introduction to the Botany of the Challenger Expedition. Report of the scientific results of the voyage of H.M.S. Challenger. Botany, Vol. I. 1885. 
Hooker, J. D. Flora of British India. Vol. I.-VIr. London, 1875-1897.

Hooker, W. J. Species filicum. Vol. I.-V. London, 1846-1864.

Kerner, A. Pflanzenleben. II. [Kerner's Natural History of Plants, edited by F. W. Oliver.]

Koorders, S. H. Notizen über die Phanerogamenflora von Java (Iv.). Natuurkundig Tijdschrift voor Nederlandsch-Indië. Bd. 60. 1901.

— and Th. Valeton. Bijdragen t. d. Kennis d. Boomsorten of Java. No. I.-x. $1873-1904$.

Kruyff, E. de. Sur une bactérie aérobe, fixant l'azote libre de l'atmosphère: Bacterium Krakataui. Bulletin du Dép. de l'agriculture aux Indes néerlandaises. No. Iv. (Mikro-Biologie II.) Buitenzorg, 1906.

Lotsy, J. P. Vorlesungen tiber Deszendenztheorien. II. Teil. Jena, 1908.

Miquel, F. A. W. Flora van Nederlandsch Indie mit Suppl.: Prodromus florae Sumatranae. Amsterdam, 1855-1860.

Neumayer, G. (Direktion der deutschen Seewarte.) Segelhandbuch für den indischen Ozean. Hamburg, 1892.

Anleitung zu wissenschaftlichen Beobachtungen auf Reisen. III. Edit. 1906.

Penzig, 0. Die Fortsehritte der Flora des Krakatau. Amnales du jardin botanique de Buitenzorg, 1902. II. séric, Vol. III.

Pulle, A. A. De nieuwe flora van Krakatau. Overgedrukt uit "De indische Merkur," 21 April, 1908.

Raciborski, M. Die Pteridophyten der Flora von Buitenzorg. Leiden, 1898.

Rollier, L. Une pluie de pierres survenue à Trélcx (Vand) le 20 février 1907. Archives des Sciences physiques et naturelles, Oct. et Nov. 1907. (Comptes rendus des travaux présentés à la 90 session de la Soeiété helvétique des sciences naturelles à Fribourg, 1907, 1. 73.)

[Schimper, A. F. W. P'lant Gcography upon a Physiological Basis. Translated by W. R. Fisher, B.A.; revised and edited by Dr Percy Groom and Prof. Bayley Balfour. Oxford, 1903.]

- Die Indomalayische Strandflora. Jena, 1891.

Selenka, E. and L. Sonnige Welten. Ostasiatische Reiseskizzen. II. Edit. Wiesbaden, 1905.

Semon, R. Im australischen Busch und an den Küsten des Korallenmeeres. II. Edit. Leipzig, 1903.

Smith, J. J. Die Orehideen von Java. Leiden, 1905.

[Tansley, A. G., and F. E. Fritsch. The Flora of the Ceylon Littoral. New Phytologist, Vol. Iv. 1905, p. 1.]

Treub, M. Notice sur la nouvelle Flore de Krakatau. Annales du jardin botanique de Buitenzorg. Vol. viI. 1888.

- Over het nieuwe Plantenkleed van Krakatau. Natuurkundig Tijdschrift voor Neederlandsch-Indië. Bd. 48. 1889

Verbeek, R. D. M. Topographische cn geologische beschrijving van Zuid-Sumatra. Jaarboek van het Mijnwezen in N. O. J. 1881. Deel I., Pag. 154-156; 179-181 ; 214-215.

Krakatan. Batavia, 1885.

Vogler, P. Über dic Verbreitungsmittel der schweizerischen Alpenpflanzen. Flora. Bd. 89. 1901.

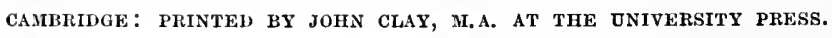





